\title{
Selected Ground-Water Data for Yucca Mountain Region, Southern Nevada and Eastern California, Through December 1999
}

Open-File Report 00-479

Prepared in cooperation with the

NEVADA OPERATIONS OFFICE of the

U.S. DEPARTMENT OF ENERGY, under

Interagency Agreement DE-Al08-92NV10874

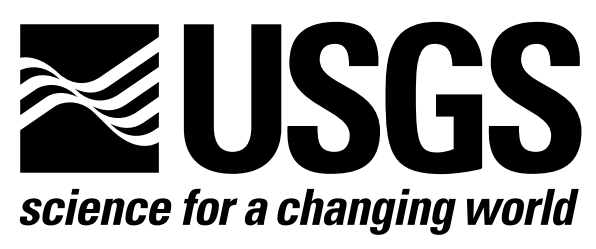


U.S. Department of the Interior

U.S. Geological Survey

\section{Selected Ground-Water Data for Yucca Mountain Region, Southern Nevada and Eastern California, Through December 1999}

By Glenn L. Locke

Open-File Report 00-479

Prepared in cooperation with the

NEVADA OPERATIONS OFFICE of the

U.S. DEPARTMENT OF ENERGY, under

Interagency Agreement DE-Al08-92NV10874

Carson City, Nevada 


\title{
U.S. DEPARTMENT OF THE INTERIOR GALE A. NORTON, Secretary
}

\author{
U.S. GEOLOGICAL SURVEY
}

CHARLES G. GROAT, Director

Any use of trade, product, or firm names in this publication is for descriptive purposes only and does not imply endorsement by the U.S. Government

For additional information contact:

District Chief

U.S. Geological Survey 333 West Nye Lane, Room 203

Carson City, NV 89706-0866

email: GS-W-NVpublic-info@usgs.gov

http://nevada.usgs.gov
Copies of this report can be purchased from:

U.S. Geological Survey Information Services

Building 810

Box 25286, Federal Center

Denver, CO 80225-0286 


\section{CONTENTS}

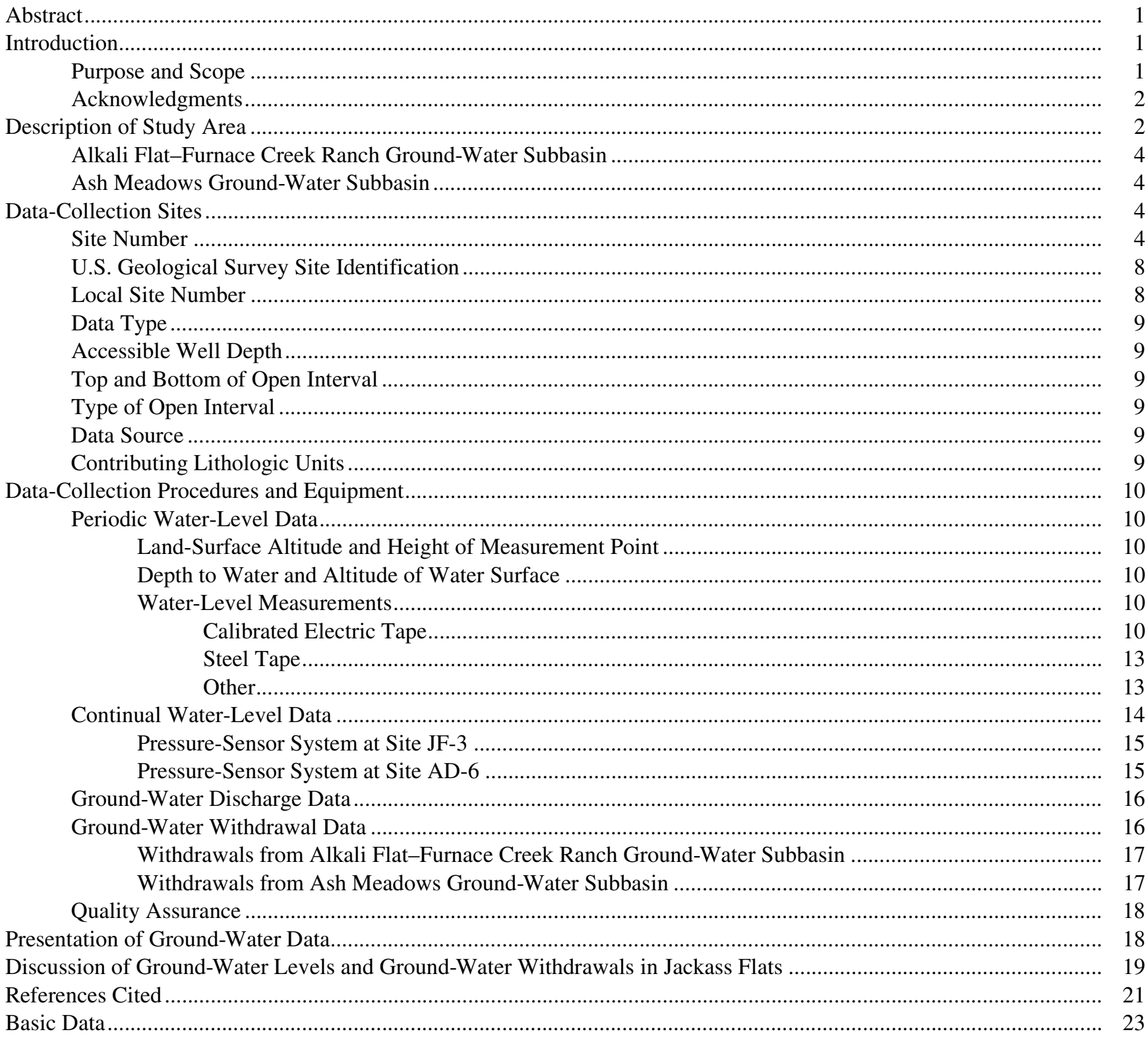

\section{FIGURES}

1. Map showing location of data-collection sites for calendar year 1999, Yucca Mountain region of southern

Nevada and eastern California

2-5. Graphs showing periodic water levels through 1999 for selected sites at which primary contributing units are:

2. Carbonate rock

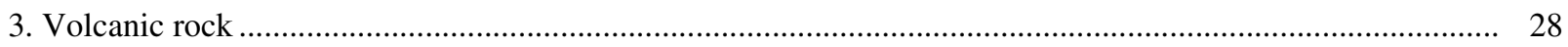

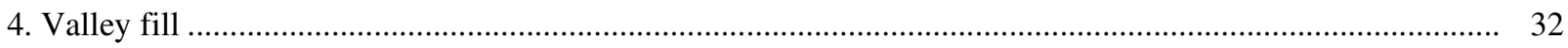

5. Undifferentiated sedimentary rock.............................................................................................. 42

6. Graph showing daily average water levels in Well JF-3, May 1992 through December 1999 and in

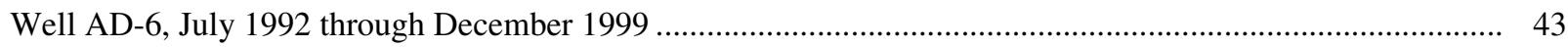


7-9. Graphs showing discharge at:

7. Sites AM-1a (Fairbanks Spring), AM-5a (Crystal Pool), and AM-8 (Big Spring) through 1999

8. Sites AM-2 (Five Springs Well) and DV-2 (Navel Spring), 1990 through 1999

9. Site DV-1 (Texas Spring), 1989 through 1999

10-11. Graphs showing available estimates of annual ground-water withdrawals for selected areas within:

10. Alkali Flat-Furnace Creek Ranch ground-water subbasin, 1961 through 1999 …….................................... 47

11. Ash Meadows ground-water subbasin, 1962 through 1999 .......................................................................... 48

12. Graphs showing water-level altitudes in wells JF-1, JF-2, JF-2a, J-13, J-11, J-12, and JF-3, and

estimated annual ground-water withdrawals from Jackass Flats, 1983 through 1999

13. Graphs showing median water-level altitudes and average deviation of water levels for wells JF-1,

JF-2, JF-2a, J-13, J-11, J-12, and JF-3, and estimated annual ground-water withdrawals from

Jackass Flats, for selected baseline periods, and for calendar years 1992 through 1999.

\section{TABLES}

1. Index to monitoring sites in Yucca Mountain region for calendar year 1999 .......................................................... 5

2. Well-completion data at monitoring sites in Yucca Mountain region........................................................................ 6

3. Electric-tape calibration data used to derive correction factors for calendar year 1999 ............................................. 12

4. Applied correction factors for electric tapes used during calendar year 1999 .......................................................... 13

5. Periodic water-level data at monitoring sites in Yucca Mountain region for calendar year 1999 .................................. 55

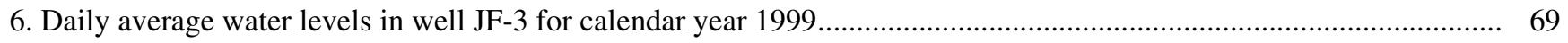

7. Daily average water levels in well AD-6 for calendar year 1999........................................................................ 70

8. Ground-water-discharge data at monitoring sites in Yucca Mountain region for calendar year 1999.......................... 71

9. Estimated annual ground-water withdrawals from wells in Yucca Mountain region for calendar year 1999 ................. 73

10. Minimum, maximum, and median water-level altitudes, and average deviation of measurements, at wells in Jackass Flats for selected baseline periods and for calendar years 1992 through 1999

\section{CONVERSION FACTORS AND VERTICAL DATUM}

\begin{tabular}{rcl}
\hline Multiply & By & To obtain \\
\hline acre-foot (acre-ft) & 1,233 & cubic meter \\
foot (ft) & 0.3048 & meter \\
gallon per minute (gal/min) & 0.06309 & liter per second \\
inch (in.) & 2.54 & centimeter \\
mile (mi) & 1.609 & kilometer \\
million gallons (Mgal) & 3,785 & cubic meter \\
pound per square inch (lb/in $\left.{ }^{2}\right)$ & 6.895 & kilopascal
\end{tabular}

Sea level: In this report, "sea level" refers to the National Geodetic Vertical Datum of 1929 (NGVD of 1929, formerly called "Sea-Level Datum of 1929"), which is derived from a general adjustment of the first-order leveling networks of the United States and Canada. 


\title{
Selected Ground-Water Data for Yucca Mountain Region, Southern Nevada and Eastern California, through December 1999
}

\author{
By Glenn L. Locke
}

\section{ABSTRACT}

The U.S. Geological Survey, in support of the U.S. Department of Energy, Yucca Mountain Site Characterization Project, collects, compiles, and summarizes hydrologic data in the Yucca Mountain region. The data are collected to allow assessments of ground-water resources during studies to determine the potential suitability of Yucca Mountain for storing high-level nuclear waste.

Data on ground-water levels at 34 wells and a fissure (Devils Hole), ground-water discharge at 5 springs and a flowing well, and total reported ground-water withdrawals within Crater Flat, Jackass Flats, Mercury Valley, and the Amargosa Desert are presented for calendar year 1999. Data collected prior to 1999 are graphically presented and data collected by other agencies (or as part of other Geological Survey programs) are included to further indicate variations of ground-water levels, discharges, and withdrawals through time.

A statistical summary of ground-water levels at seven wells in Jackass Flats is presented to indicate potential effects of ground-water withdrawals associated with U.S. Department of Energy activities near Yucca Mountain. The statistical summary includes the number of measurements, the maximum, minimum, and median water-level altitudes, and the average deviation of measured water-level altitudes for selected baseline periods and for calendar years 1992-99. At two water-supply wells median water levels for calendar year 1999 were unchanged from their respective baseline periods. At a nearby observation well, the 1999 median water level was slightly lower ( 0.1 foot) than its baseline period. At the remaining four wells in Jackass Flats, median water levels for 1999 were slightly higher ( 0.2 foot to 1.6 feet) than for their respective baseline periods.

\section{INTRODUCTION}

Investigations are in progress or planned to determine the potential suitability of Yucca Mountain for storing high-level nuclear waste. The U.S. Department of Energy (DOE) has declared that all facilities and activities associated with such investigations will be operated in a manner that maintains or protects environmental quality, and has established programs to allow assessments of environmental quality. In April 1989, the U.S. Geological Survey (USGS) began a cooperative program with DOE to develop a groundwater-resources monitoring program in the vicinity of Yucca Mountain. The purposes of the monitoring program are to (1) document the historical and current conditions of ground-water resources, (2) detect and document changes in those resources during the investigations of Yucca Mountain, and (3) provide a basis for analyzing and identifying potential adverse effects on ground-water resources resulting from investigations of Yucca Mountain.

\section{Purpose and Scope}

This report presents and summarizes, in tabular and graphical form, data collected as part of the U.S. Geological Survey Environmental-Monitoring Program. Included are 1999 data on ground-water levels at 34 wells and a fissure (Devils Hole), groundwater discharge at 5 springs and a flowing well, and total reported ground-water withdrawals within Crater Flat, Jackass Flats, Mercury Valley, and Amargosa Desert. Data on ground-water levels, discharges, and 
withdrawals collected by other agencies (or collected as part of other USGS programs) at the sites are included also to further indicate variations through time at selected monitoring locations.

A discussion of ground-water data for Jackass Flats includes a statistical summary of that data to indicate potential effects of withdrawals from wells in Jackass Flats on water levels near Yucca Mountain. Effects of these withdrawals may be detected in Jackass Flats before they are detected elsewhere in the Yucca Mountain region.

This report is the eighth in a series of annual reports as part of the U.S. Geological Survey Environmental-Monitoring Program. Hereafter, the first seven reports are referred to as previous reports on selected ground-water data for the Yucca Mountain region. The previous reports and the data they contain are:

$\begin{array}{lc}\begin{array}{l}\text { Report (see references cited) } \\ \text { La Camera and Westenburg (1994) }\end{array} & \begin{array}{c}\text { Data contained } \\ \text { Earliest available data } \\ \text { through } 1992\end{array} \\ \text { Hale and Westenburg (1995) } & \text { Data collected in } 1993 \\ \text { Westenburg and La Camera (1996) } & \text { Data collected in } 1994 \\ \text { La Camera, Westenburg, and Locke (1996) } & \text { Data collected in } 1995 \\ \text { La Camera and Locke (1998) } & \text { Data collected in } 1996 \\ \text { La Camera, Locke, and Munson (1999) } & \text { Data collected in } 1997 \\ \text { Locke (2001) } & \text { Data collected in } 1998\end{array}$

Additional information for sites CF-2, JF-1, JF-2, $\mathrm{JF}-2 \mathrm{a}, \mathrm{J}-13, \mathrm{~J}-11$, and $\mathrm{J}-12$ is presented by Robison (1984), Robison and others (1988), Gemmel (1990), McKinley and others (1991), O’Brien (1991, 1993), Luckey and others (1993), Boucher (1994), Lobmeyer and others (1995), O'Brien and others (1995), Graves (2000), Graves and others (1996), Tucci, Goematt, and Burkhardt (1996), Tucci, O’Brien, and Burkhardt (1996), and Graves and Goemaat (1998).

\section{Acknowledgments}

Several organizations and programs contributed to this report. Specifically, data were provided by National Park Service; U.S. Fish and Wildlife Service; Nevada Department of Conservation and Natural Resources, Division of Water Resources; Nevada Department of Transportation; Barrick Bullfrog Inc.; Bechtel Nevada; Cathedral Gold U.S. Corporation; Cind-R-Lite Company; Daisy Gold Mining Company; U.S. Borax Corporation; U.S. Nevada Gold Search; USGS-Hydrologic Resources Management and Envi- ronmental Restoration Programs; and USGS-Yucca Mountain Project Branch studies of saturated-zone site hydrology and saturated-zone regional hydrology.

Additionally, the author acknowledges the cooperation of the many individual property owners throughout the Amargosa Desert who allowed access to their property for the collection of hydrologic data.

\section{DESCRIPTION OF STUDY AREA}

The study area is the Yucca Mountain region of southern Nevada and eastern California (fig. 1). The boundary of the Yucca Mountain region, for purposes of this report, roughly coincides with the northern parts of Crater Flat and Jackass Flats, eastern parts of Rock Valley, Mercury Valley, and Amargosa Desert, Nev., and Death Valley Junction and Furnace Creek, Calif., to the south and west. The region is within the Great Basin, a subdivision of the Basin and Range Physiographic Province (Fenneman, 1931, p. 328).

The study area is in the Death Valley groundwater flow system (Harrill and others, 1988, sheet 1) and, within that flow system, the Alkali Flat-Furnace Creek Ranch and Ash Meadows ground-water subbasins. Each ground-water subbasin is a zone consisting of ground-water recharge areas and flow paths to points of discharge at land surface (Waddell and others, 1984, p. 36; Laczniak and others, 1996, p. 16 and pl. 1). Boundaries of the subbasins are defined on the basis of the location of recharge areas, discharge areas, low-permeability rocks, hydraulic gradients, and water chemistry. These boundaries are general indicators of restrictions on ground-water movement in the region.

The study area is also subdivided by hydrographic areas ${ }^{1}$ (fig. 1). As defined by Rush (1968, p. 4), hydrographic areas generally consist of valleys (topographic lows) extending to their surrounding surface-water drainage divides (topographic highs). Hydrographic areas in the study area include Crater

\footnotetext{
${ }^{1}$ Formal hydrographic areas in Nevada were delineated systematically by the U.S. Geological Survey and Nevada Division of Water Resources in the late 1960's for scientific and administrative purposes (Rush, 1968; Cardinalli and others, 1968). The official hydrographic area names, numbers, and geographic boundaries continue to be used in Geological Survey scientific reports and Division of Water Resources administrative activities. Extensions of hydrographic areas from Nevada into California and selected hydrographic areas in California have been delineated also by Harrill and others (1988, sheet 2).
} 


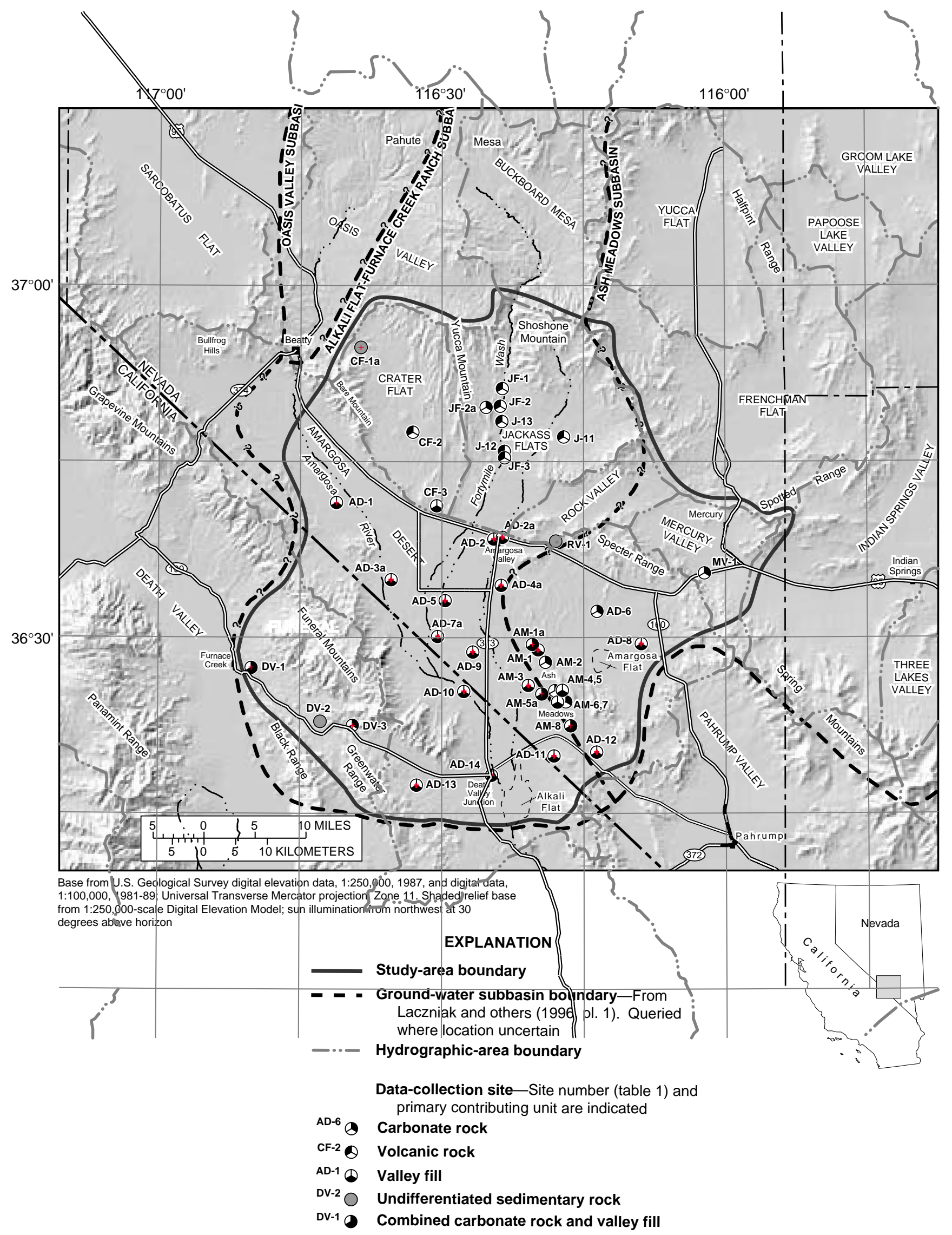

Figure 1. Location of data-collection sites for calendar year 1999, Yucca Mountain region of southern Nevada and eastern California. 
Flat, Jackass Flats, and Rock Valley, most of Mercury Valley and Amargosa Desert, and part of Death Valley (Rush, 1968; Harrill and others, 1988, sheet 2).

\section{Alkali Flat-Furnace Creek Ranch Ground-Water Subbasin}

Crater Flat and Jackass Flats (which include Yucca Mountain), most of Rock Valley, the westcentral part of the Amargosa Desert, and part of Death Valley are in the Alkali Flat-Furnace Creek Ranch ground-water subbasin (fig. 1). Within this subbasin, sources of ground water principally are precipitation and subsurface inflow (Laczniak and others, 1996, table 3; Waddell and others, 1984, p. 36; Harrill and others, 1988, sheet 2). Precipitation occurs on the higher mesas and mountains within the subbasin and along the subbasin's north and northeast mountainous boundaries. Inflow into the subbasin occurs near Beatty from the Oasis Valley subbasin, near Ash Meadows from the Ash Meadows subbasin, and from Cactus Flat (about 40 miles (mi) north of Beatty). Ground water discharges principally as springflow in Death Valley and as evapotranspiration from Alkali Flat and Death Valley. Ground water generally flows to the south, southeast, or southwest and discharges principally in Death Valley and at Alkali Flat (Kilroy, 1991, p. 9-13; Laczniak and others, 1996, pl. 1; Tucci and Burkhardt, 1995, p. 8).

\section{Ash Meadows Ground-Water Subbasin}

Part of Rock Valley, most of Mercury Valley, and the eastern part of the Amargosa Desert are within the Ash Meadows subbasin (fig. 1). The southeastern part of the Amargosa Desert includes the Ash Meadows spring-discharge area. The Ash Meadows springdischarge area is a gently sloping land watered by numerous springs (Dudley and Larson, 1976, p. 5) at the southwestern edge of the subbasin.

In the Ash Meadows ground-water subbasin, sources of ground water principally are precipitation and subsurface inflow (Laczniak and others, 1996, table 3). Precipitation occurs on the higher mountains within the subbasin and along the subbasin's north and northeast mountainous boundaries. Inflow occurs from Railroad Valley and Pahranagat Valley along the basin's north and northeast boundaries (about 100 mi north of Ash Meadows). Ground water discharges principally as springflow and evapotranspiration in the Ash Meadows area and possibly as underflow into the Alkali Flat-Furnace Creek Ranch ground-water subbasin. Ground water in the subbasin generally flows to the south, west, or southwest (Harrill and others, 1988, sheet 2; Laczniak and others, 1996, p. 16-18 and pl. 1).

\section{DATA-COLLECTION SITES}

Locations of data-collection sites are shown in figure 1. Information on site identification, site location, site owner, and the types of data contained in this report are given in table 1 for each site. Data on well construction, sources of well-construction data, and contributing lithologic units are given in table 2. All sites are wells or springs except site AM-4 (Devils Hole), which is an open fissure that intersects the ground-water table.

\section{Site Number}

Sites in this report are identified by an alphanumeric number consisting of two parts. The first part represents the hydrographic area in which the site is located: "CF" represents Crater Flat; "JF" or "J," Jackass Flats; "RV," Rock Valley; "MV," Mercury Valley; "AD" or "AM," Amargosa Desert; and "DV," Death Valley. "AM" further indicates that the site is located in the Ash Meadows spring-discharge area. The second part of the number represents the relative location of the site within the hydrographic area (or Ash Meadows spring-discharge area). Within each hydrographic area, sites generally are numbered sequentially in a north-to-south, then west-to-east order. Sites added subsequent to the initial numbering also are numbered as indicated above or are assigned the number of a nearby site and given the suffix "a." Exceptions are sites $\mathrm{J}-13, \mathrm{~J}-11$, and $\mathrm{J}-12$, which are or were intended water-supply wells and were previously numbered by Raytheon Services Nevada; they were not renumbered for this report. The sequence of sites in table 1 is followed throughout the report. 
Table 1. Index to monitoring sites in Yucca Mountain region for calendar year 1999

Site number: Sites are grouped by hydrographic area and, within each area, are listed in general north-to-south, then west-to-east order. See section "Site Number" for further discussion.

U.S. Geological Survey site identification: Unique identification number for sites as stored in files and data bases of U.S. Geological Survey.

Local site number: Alphanumeric number based on location of site within hydrographic areas and rectangular subdivisions of public lands. See section "Local Site Number" for further discussion.

Owner: Abbreviations listed for sites owned by federal agencies: BLM, Bureau of Land Management; NPS, National Park Service; DOE, U.S. Department of Energy; USFWS, U.S. Fish \& Wildlife Service; USGS, U.S. Geological Survey.

Data type: Type of data included in this report: D, ground-water discharge; L, ground-water level.

\begin{tabular}{|c|c|c|c|c|c|c|c|c|}
\hline \multirow{2}{*}{$\begin{array}{c}\begin{array}{c}\text { Site } \\
\text { number } \\
\text { (fig. 1) }\end{array} \\
\text { CF-1a }\end{array}$} & \multirow{2}{*}{$\begin{array}{c}\begin{array}{c}\text { U.S. Geological } \\
\text { Survey site } \\
\text { identification }\end{array} \\
365445116383901 \\
\end{array}$} & \multirow{2}{*}{$\begin{array}{l}\text { Site name } \\
\text { GEXA Well } 3\end{array}$} & \multirow{2}{*}{$\begin{array}{l}\text { Latitude } \\
36^{\circ} 54^{\prime} 42^{\prime \prime}\end{array}$} & \multirow{2}{*}{$\begin{array}{l}\text { Longitude } \\
116^{\circ} 38^{\prime} 41^{\prime \prime}\end{array}$} & \multicolumn{2}{|c|}{ Local site number } & \multirow{2}{*}{$\begin{array}{c}\text { Owner } \\
\text { Rayrock Mines, Inc. }\end{array}$} & \multirow{2}{*}{$\begin{array}{c}\text { Data } \\
\text { type }\end{array}$} \\
\hline & & & & & 229 & S12 E48 07ADD1 & & \\
\hline $\mathrm{CF}-2$ & 364732116330701 & USW VH-1 & $36^{\circ} 47^{\prime} 32^{\prime \prime}$ & $116^{\circ} 33^{\prime} 07^{\prime \prime}$ & 229 & S13 E48 27C1 & DOE & $\mathrm{L}$ \\
\hline $\mathrm{CF}-3$ & 364105116302601 & Cind-R-Lite Well & $36^{\circ} 41^{\prime} 06^{\prime \prime}$ & $116^{\circ} 30^{\prime} 26^{\prime \prime}$ & 229 & S14 E48 36DDD1 & Cind-R-Lite Block Company & $\mathrm{L}$ \\
\hline JF-1 & 365116116233801 & UE-25 WT 15 & $36^{\circ} 51^{\prime} 16^{\prime \prime}$ & $116^{\circ} 23^{\prime} 38^{\prime \prime}$ & $227 \mathrm{~A}$ & S12 E50 33A1 & DOE & $\mathrm{L}$ \\
\hline $\mathrm{JF}-2$ & 364945116235001 & UE-25 WT 13 & $36^{\circ} 49^{\prime} 43^{\prime \prime}$ & $116^{\circ} 23^{\prime} 51^{\prime \prime}$ & $227 \mathrm{~A}$ & $\mathrm{~S} 13 \mathrm{E} 5018 \mathrm{~B} 1$ & DOE & $\mathrm{L}$ \\
\hline$J F-2 a$ & 364938116252102 & UE-25p 1 PTH & $36^{\circ} 49^{\prime} 38^{\prime \prime}$ & $116^{\circ} 25^{\prime} 21^{\prime \prime}$ & $227 \mathrm{~A}$ & S13 E49 14A2 & DOE & $\mathrm{L}$ \\
\hline $\mathrm{J}-13$ & 364828116234001 & $\mathrm{~J}-13 \mathrm{WW}$ & $36^{\circ} 48^{\prime} 29^{\prime \prime}$ & $116^{\circ} 23^{\prime} 40^{\prime \prime}$ & $227 \mathrm{~A}$ & S13 E50 19C1 & DOE & $\mathrm{L}$ \\
\hline $\mathrm{J}-11$ & 364706116170601 & J-11 WW & $36^{\circ} 47^{\prime} 06^{\prime \prime}$ & $116^{\circ} 17^{\prime} 06^{\prime \prime}$ & $227 \mathrm{~A}$ & S13 E51 31B1 & DOE & $\mathrm{L}$ \\
\hline $\mathrm{J}-12$ & 364554116232401 & $\mathrm{~J}-12 \mathrm{WW}$ & $36^{\circ} 45^{\prime} 54^{\prime \prime}$ & $116^{\circ} 23^{\prime} 24^{\prime \prime}$ & $227 \mathrm{~A}$ & S14 E50 06A2 & DOE & $\mathrm{L}$ \\
\hline $\mathrm{JF}-3$ & 364528116232201 & JF-3 Well & $36^{\circ} 45^{\prime} 28^{\prime \prime}$ & $116^{\circ} 23^{\prime} 22^{\prime \prime}$ & $227 \mathrm{~A}$ & S14 E50 06D1 & DOE & $\mathrm{L}$ \\
\hline $\mathrm{RV}-1$ & 363815116175901 & TW-5 & $36^{\circ} 38^{\prime} 15^{\prime \prime}$ & $116^{\circ} 17^{\prime} 59^{\prime \prime}$ & 226 & S15 E50 24A1 & DOE & $\mathrm{L}$ \\
\hline MV-1 & 363530116021401 & Army $1 \mathrm{WW}$ & $36^{\circ} 35^{\prime} 30^{\prime \prime}$ & $116^{\circ} 02^{\prime} 14^{\prime \prime}$ & 225 & S16 E53 05ADB1 & DOE & $\mathrm{L}$ \\
\hline $\mathrm{AD}-1$ & 364141116351401 & NA-6 Well BGMW-10 & $36^{\circ} 41^{\prime} 31^{\prime \prime}$ & $116^{\circ} 41^{\prime} 14^{\prime \prime}$ & 230 & S14 E47 32DA1 & USGS & $\mathrm{L}$ \\
\hline AD-2 & 363830116241401 & Airport Well & $36^{\circ} 38^{\prime} 25^{\prime \prime}$ & $116^{\circ} 24^{\prime} 33^{\prime \prime}$ & 230 & S15 E49 24ABB1 & Doing, Warren & $\mathrm{L}$ \\
\hline $\mathrm{AD}-2 \mathrm{a}$ & 363835116234001 & NDOT Well & $36^{\circ} 38^{\prime} 35^{\prime \prime}$ & $116^{\circ} 23^{\prime} 58^{\prime \prime}$ & 230 & S15 E50 18CCDB1 & Nev. Dept. of Transportation & $\mathrm{L}$ \\
\hline $\mathrm{AD}-3 \mathrm{a}$ & 363521116352501 & Davidson Well & $36^{\circ} 35^{\prime} 25^{\prime \prime}$ & $116^{\circ} 35^{\prime} 30^{\prime \prime}$ & 230 & S16 E48 05CAB1 & Davidson, Robert & $\mathrm{L}$ \\
\hline $\mathrm{AD}-4 \mathrm{a}$ & 363428116234701 & Cooks East Well & $36^{\circ} 34^{\prime} 30^{\prime \prime}$ & $116^{\circ} 23^{\prime} 45^{\prime \prime}$ & 230 & S16 E50 07CABB1 & Cook, Lewis C. & $\mathrm{L}$ \\
\hline AD-5 & 363310116294001 & USBLM Well & $36^{\circ} 33^{\prime} 25^{\prime \prime}$ & $116^{\circ} 29^{\prime} 45^{\prime \prime}$ & 230 & S16 E49 18DCCA1 & BLM & $\mathrm{L}$ \\
\hline AD-6 & 363213116133800 & Tracer Well 3 & $36^{\circ} 32^{\prime} 13^{\prime \prime}$ & $116^{\circ} 13^{\prime} 38^{\prime \prime}$ & 230 & S16 E51 27BAA3 & USGS & $\mathrm{L}$ \\
\hline $\mathrm{AD}-7 \mathrm{a}$ & 363009116302702 & Blackman Well & $36^{\circ} 30^{\prime} 10^{\prime \prime}$ & $116^{\circ} 30^{\prime} 30^{\prime \prime}$ & 230 & S17 E48 01AB3 & Naxos Mining Company & $\mathrm{L}$ \\
\hline AD-8 & 362929116085701 & Cherry Patch Well & $36^{\circ} 29^{\prime} 30^{\prime \prime}$ & $116^{\circ} 08^{\prime} 55^{\prime \prime}$ & 230 & S17 E52 08CDB1 & Clark, Hershel, and others & $\mathrm{L}$ \\
\hline AD-9 & 362848116264201 & Gilgans North Well & $36^{\circ} 28^{\prime} 50^{\prime \prime}$ & $116^{\circ} 26^{\prime} 45^{\prime \prime}$ & 230 & S17 E49 15BBBB1 & Steelman, James C. & $\mathrm{L}$ \\
\hline $\mathrm{AD}-10$ & 362525116274301 & NA-9 Well & $36^{\circ} 25^{\prime} 30^{\prime \prime}$ & $116^{\circ} 27^{\prime} 40^{\prime \prime}$ & 230 & 026N005E05E001S & USGS & $\mathrm{L}$ \\
\hline AD-11 & 361954116181201 & GS-3 Well & $36^{\circ} 19^{\prime} 57^{\prime \prime}$ & $116^{\circ} 17^{\prime} 52^{\prime \prime}$ & 230 & S19 E50 01BBD1 & USGS & $\mathrm{L}$ \\
\hline $\mathrm{AD}-12$ & 362014116133901 & GS-1 Well & $36^{\circ} 20^{\prime} 21^{\prime \prime}$ & $116^{\circ} 13^{\prime} 30^{\prime \prime}$ & 230 & S18 E51 34CBD1 & USGS & $\mathrm{L}$ \\
\hline $\mathrm{AD}-13$ & 361724116324201 & S-1 Well & $36^{\circ} 17^{\prime} 20^{\prime \prime}$ & $116^{\circ} 32^{\prime} 40^{\prime \prime}$ & 230 & 025N004E21M001S & USGS & $\mathrm{L}$ \\
\hline $\mathrm{AD}-14$ & 361817116244701 & Death Valley Jct Well & $36^{\circ} 18^{\prime} 16^{\prime \prime}$ & $116^{\circ} 24^{\prime} 47^{\prime \prime}$ & 230 & 025N005E14M001S & Ettie, Lee & $\mathrm{L}$ \\
\hline AM-1 & 362858116195301 & Rogers Spring Well & $36^{\circ} 28^{\prime} 55^{\prime \prime}$ & $116^{\circ} 19^{\prime} 50^{\prime \prime}$ & 230 & S17 E50 10CDD1 & USFWS & $\mathrm{L}$ \\
\hline AM-1a & 362924116203001 & Fairbanks Spring & $36^{\circ} 29^{\prime} 26^{\prime \prime}$ & $116^{\circ} 20^{\prime} 28^{\prime \prime}$ & 230 & S17 E50 09AD1 & USFWS & $\mathrm{D}$ \\
\hline $\mathrm{AM}-2$ & 362755116190401 & Five Springs Well & $36^{\circ} 27^{\prime} 55^{\prime \prime}$ & $116^{\circ} 19^{\prime} 05^{\prime \prime}$ & 230 & S17 E50 23BBCA1 & USFWS & $\mathrm{D}, \mathrm{L}$ \\
\hline AM-3 & 362555116205301 & Garners Well & $36^{\circ} 25^{\prime} 55^{\prime \prime}$ & $116^{\circ} 20^{\prime} 55^{\prime \prime}$ & 230 & S17 E50 33CAAB1 & Garner, George & $\mathrm{L}$ \\
\hline AM-4 & 362532116172700 & Devils Hole & $36^{\circ} 25^{\prime} 32^{\prime \prime}$ & $116^{\circ} 17^{\prime} 27^{\prime \prime}$ & 230 & S17 E50 36DC1 & NPS & $\mathrm{L}$ \\
\hline AM-5 & 362529116171100 & Devils Hole Well & $36^{\circ} 25^{\prime} 30^{\prime \prime}$ & $116^{\circ} 17^{\prime} 15^{\prime \prime}$ & 230 & S17 E50 36DDC1 & USFWS & $\mathrm{L}$ \\
\hline AM-5a & 362502116192301 & Crystal Pool & $36^{\circ} 25^{\prime} 15^{\prime \prime}$ & $116^{\circ} 19^{\prime} 25^{\prime \prime}$ & 230 & S18 E50 03ADBA1 & USFWS & $\mathrm{D}$ \\
\hline AM-6 & 362432116165701 & Point of Rocks North Well & $36^{\circ} 24^{\prime} 30^{\prime \prime}$ & $116^{\circ} 16^{\prime} 55^{\prime \prime}$ & 230 & S18 E51 07BBBB1 & USFWS & $\mathrm{L}$ \\
\hline AM-7 & 362417116163600 & Point of Rocks South Well & $36^{\circ} 24^{\prime} 20^{\prime \prime}$ & $116^{\circ} 16^{\prime} 40^{\prime \prime}$ & 230 & S18 E51 07BDB1 & USFWS & $\mathrm{L}$ \\
\hline AM-8 & 362230116162001 & Big Spring & $36^{\circ} 22^{\prime} 29^{\prime \prime}$ & $116^{\circ} 16^{\prime} 25^{\prime \prime}$ & 230 & S18 E51 19ACB1 & USFWS & $\mathrm{D}$ \\
\hline DV-1 & 362728116501101 & Texas Spring & $36^{\circ} 27^{\prime} 28^{\prime \prime}$ & $116^{\circ} 50^{\prime} 11^{\prime \prime}$ & 243 & 027N001E23BS01S & NPS & $\mathrm{D}$ \\
\hline DV-2 & 362252116425301 & Navel Spring & $36^{\circ} 22^{\prime} 52^{\prime \prime}$ & $116^{\circ} 42^{\prime} 53^{\prime \prime}$ & 243 & 026N002E13FS01S & U.S. Borax \& Chem. Corp. & $\mathrm{D}$ \\
\hline DV -3 & 362230116392901 & Travertine Point 1 Well & $36^{\circ} 22^{\prime} 31^{\prime \prime}$ & $116^{\circ} 39^{\prime} 32^{\prime \prime}$ & 243 & 026N003E21L001S & U.S. Borax \& Chem. Corp. & $\mathrm{L}$ \\
\hline
\end{tabular}


Table 2. Well-completion data at monitoring sites in Yucca Mountain region

Site number: Sites are grouped by hydrographic area and, within each area, are listed in general north-to-south, then west-to-east order. See section "Site Number" for further discussion.

U.S. Geological Survey site identification: Unique identification number for site as stored in files and data bases of U.S. Geological Survey (USGS).

Accessible well depth: Well depths listed are as reported in sources listed in explanation for Data source (see below) or as measured by USGS personnel (noted with "s"). See section "Accessible Well Depth" for further discussion.

Casing diameter at land surface: Outside casing diameter of segment most prominent at land surface; rounded to nearest inch.

Top of open interval: Depth to top part(s) of well that can receive ground water from lithologic interval. Uncased borehole is designated open interval in this table. Open interval may be deeper than accessible well depth, which may reflect original drilled depth. As reported in sources listed in explanation for Data source (see below). U, unknown, no data.

Bottom of open interval: Depth to bottom part(s) of well that can receive ground water from lithologic interval. Uncased borehole is designated open interval in this table. Open interval may be deeper than accessible well depth, which may reflect original drilled depth. As reported in sources listed in explanation for Data source (see below). U, unknown or no data.

Diameter of open interval: Inside casing diameter; rounded to nearest inch. Hole diameter is listed where no casing is present. U, unknown or no data.

Type of open interval: Description of open interval: P, perforated or slotted casing; S, screened casing, type not known; U, unknown, no data; X, uncased borehole.

Data source: D, Well driller's log, well-completion report, or Fenix \& Scisson, Inc., or Raytheon Services Nevada hole-history data; J. Johnston (1968); M, no source, data not available; O, owner of well; R, Robison and others (1988); T, Thordarson and others (1967).

Contributing units: Saturated lithologic interval yielding water to well: C, carbonate rock; F, valley fill; S, undifferentiated sedimentary rock; V, volcanic TacR. See section "Contributing Lithologic Units" for further discussion.

\begin{tabular}{|c|c|c|c|c|c|c|c|c|c|c|}
\hline \multirow{3}{*}{$\begin{array}{c}\text { Site } \\
\text { number } \\
\text { (fig. 1) }\end{array}$} & \multirow{3}{*}{$\begin{array}{l}\text { U.S. Geological } \\
\text { Survey site } \\
\text { identification }\end{array}$} & \multirow{3}{*}{ Site name } & \multirow{3}{*}{$\begin{array}{l}\text { Accessible } \\
\text { well depth } \\
\text { (feet below } \\
\text { land } \\
\text { surface) }\end{array}$} & \multirow{3}{*}{$\begin{array}{l}\text { Casing } \\
\text { diameter } \\
\text { at land } \\
\text { surface } \\
\text { (inches) }\end{array}$} & \multicolumn{4}{|c|}{ Open interval } & \multirow{3}{*}{$\begin{array}{l}\text { Data } \\
\text { source }\end{array}$} & \multirow{3}{*}{$\begin{array}{c}\text { Contributing } \\
\text { units }\end{array}$} \\
\hline & & & & & \multicolumn{2}{|c|}{$\begin{array}{l}\text { Feet below } \\
\text { land surface }\end{array}$} & \multirow{2}{*}{$\begin{array}{l}\text { Diameter } \\
\text { (inches) }\end{array}$} & \multirow{2}{*}{ Type } & & \\
\hline & & & & & Top & Bottom & & & & \\
\hline \multirow[t]{3}{*}{ CF-1a } & 365445116383901 & GEXA Well 3 & 700 & 7 & 208 & 313 & 6 & $\mathrm{P}$ & $\mathrm{D}$ & $\mathrm{S}$ \\
\hline & & & & & 513 & 618 & 6 & $\mathrm{P}$ & & \\
\hline & & & & & 658 & 700 & 6 & $\mathrm{P}$ & & \\
\hline \multirow[t]{2}{*}{$\mathrm{CF}-2$} & 364732116330701 & USW VH-1 & 2,501 & 10 & 911 & 912 & 9 & $X$ & $\mathrm{R}$ & $\mathrm{V}$ \\
\hline & & & & & 912 & 2,501 & 6 & $X$ & & \\
\hline $\mathrm{CF}-3$ & 364105116302601 & Cind-R-Lite Well & 460 & 9 & 320 & 460 & 8 & $\mathrm{P}$ & $\mathrm{D}$ & $\mathrm{F}$ \\
\hline \multirow[t]{2}{*}{$\mathrm{JF}-1$} & 365116116233801 & UE-25 WT 15 & 1,360 & 11 & 127 & 130 & 15 & $X$ & $\mathrm{D}$ & V \\
\hline & & & & & 130 & 1,360 & 9 & $X$ & & \\
\hline \multirow[t]{3}{*}{$\mathrm{JF}-2$} & 364945116235001 & UE-25 WT 13 & 1,160 & 11 & 222 & 224 & 15 & $X$ & $\mathrm{D}$ & $\mathrm{V}$ \\
\hline & & & & & 224 & 1,150 & 9 & $X$ & & \\
\hline & & & & & 1,150 & 1,160 & 8 & $X$ & & \\
\hline \multirow[t]{3}{*}{$J F-2 a$} & 364938116252102 & UE-25p 1 PTH & 5,923 & 24 & 4,256 & 4,279 & 10 & $X$ & $\mathrm{R}$ & $\mathrm{C}$ \\
\hline & & & & & 4,279 & 5,900 & 7 & $X$ & & \\
\hline & & & & & 5,900 & 5,923 & 6 & $X$ & & \\
\hline \multirow[t]{4}{*}{$\mathrm{J}-13$} & 364828116234001 & $\mathrm{~J}-13 \mathrm{WW}$ & 3,488 & 13 & 996 & 1,301 & 13 & $\mathrm{P}$ & $\mathrm{T}$ & V \\
\hline & & & & & 1,301 & 1,386 & 11 & $\mathrm{P}$ & & \\
\hline & & & & & 2,690 & 3,312 & 5 & $\mathrm{P}$ & & \\
\hline & & & & & 3,385 & 3,488 & 8 & $\mathrm{X}$ & & \\
\hline \multirow[t]{2}{*}{$\mathrm{J}-11$} & 364706116170601 & $\mathrm{~J}-11 \mathrm{WW}$ & 1,327 & 13 & 1,075 & 1,095 & 12 & $\mathrm{P}$ & $\mathrm{D}$ & V \\
\hline & & & & & 1,242 & 1,298 & 12 & $\mathrm{P}$ & & \\
\hline
\end{tabular}


Table 2. Well-completion data at monitoring sites in Yucca Mountain region-Continued

\begin{tabular}{|c|c|c|c|c|c|c|c|c|c|c|}
\hline \multirow{3}{*}{$\begin{array}{c}\text { Site } \\
\text { number } \\
\text { (fig. 1) }\end{array}$} & \multirow{3}{*}{$\begin{array}{l}\text { U.S. Geological } \\
\text { Survey site } \\
\text { identification }\end{array}$} & \multirow{3}{*}{ Site name } & \multirow{3}{*}{$\begin{array}{c}\text { Accessible } \\
\text { well depth } \\
\text { (feet below } \\
\text { land } \\
\text { surface) }\end{array}$} & \multirow{3}{*}{$\begin{array}{c}\text { Casing } \\
\text { diameter } \\
\text { at land } \\
\text { surface } \\
\text { (inches) }\end{array}$} & \multicolumn{4}{|c|}{ Open interval } & \multirow{3}{*}{$\begin{array}{c}\text { Data } \\
\text { source }\end{array}$} & \multirow{3}{*}{$\begin{array}{c}\text { Contributing } \\
\text { units }\end{array}$} \\
\hline & & & & & \multicolumn{2}{|c|}{$\begin{array}{l}\text { Feet below } \\
\text { land surface }\end{array}$} & \multirow{2}{*}{$\begin{array}{c}\text { Diameter } \\
\text { (inches) }\end{array}$} & \multirow{2}{*}{ Type } & & \\
\hline & & & & & Top & Bottom & & & & \\
\hline \multirow[t]{2}{*}{$\mathrm{J}-12$} & 364554116232401 & $\mathrm{~J}-12 \mathrm{WW}$ & 1,139 & 13 & 793 & 868 & 12 & $\mathrm{P}$ & $\mathrm{D}$ & $\mathrm{V}$ \\
\hline & & & & & 887 & 1,139 & 12 & $\mathrm{X}$ & & \\
\hline \multirow[t]{4}{*}{$\mathrm{J}-13$} & 364828116234001 & $\mathrm{~J}-13 \mathrm{WW}$ & 3,488 & 13 & 996 & 1,301 & 13 & $\mathrm{P}$ & $\mathrm{T}$ & $\mathrm{V}$ \\
\hline & & & & & 1,301 & 1,386 & 11 & $\mathrm{P}$ & & \\
\hline & & & & & 2,690 & 3,312 & 5 & $\mathrm{P}$ & & \\
\hline & & & & & 3,385 & 3,488 & 8 & $\mathrm{X}$ & & \\
\hline \multirow[t]{2}{*}{$\mathrm{J}-11$} & 364706116170601 & $\mathrm{~J}-11 \mathrm{WW}$ & 1,327 & 13 & 1,075 & 1,095 & 12 & $\mathrm{P}$ & $\mathrm{D}$ & $\mathrm{V}$ \\
\hline & & & & & 1,242 & 1,298 & 12 & $\mathrm{P}$ & & \\
\hline \multirow[t]{2}{*}{$\mathrm{J}-12$} & 364554116232401 & $\mathrm{~J}-12 \mathrm{WW}$ & 1,139 & 13 & 793 & 868 & 12 & $\mathrm{P}$ & $\mathrm{D}$ & $\mathrm{V}$ \\
\hline & & & & & 887 & 1,139 & 12 & $X$ & & \\
\hline JF-3 & 364528116232201 & JF- 3 Well & 1,138 & 9 & 735 & 1,138 & 8 & $\mathrm{P}$ & $\mathrm{D}$ & $\mathrm{V}$ \\
\hline \multirow[t]{2}{*}{ RV-1 } & 363815116175901 & TW- 5 & $800 \mathrm{~s}$ & 7 & 735 & 800 & 6 & $\mathrm{P}$ & $\mathrm{T}$ & $\mathrm{S}$ \\
\hline & & & & & 800 & 916 & $\mathrm{U}$ & $\mathrm{X}$ & & \\
\hline \multirow[t]{4}{*}{ MV-1 } & 363530116021401 & Army $1 \mathrm{WW}$ & 1,953 & 11 & 800 & 1,050 & 11 & $\mathrm{P}$ & $\mathrm{D}$ & $\mathrm{C}$ \\
\hline & & & & & 1,368 & 1,370 & 10 & $\mathrm{X}$ & & \\
\hline & & & & & 1,370 & 1,684 & 9 & $\mathrm{X}$ & & \\
\hline & & & & & 1,684 & 1,953 & 7 & $\mathrm{X}$ & & \\
\hline AD-1 & 364141116351401 & NA-6 Well BGMW-10 & 960 & 2 & 930 & 940 & 2 & $\mathrm{~S}$ & $\mathrm{D}$ & $\mathrm{F}$ \\
\hline $\mathrm{AD}-2$ & 363830116241401 & Airport Well & $750 \mathrm{~s}$ & 14 & 360 & 777 & 14 & $\mathrm{P}$ & $\mathrm{D}$ & $\mathrm{F}$ \\
\hline $\mathrm{AD}-2 \mathrm{a}$ & 363835116234001 & NDOT Well & 495 & 9 & 395 & 495 & 8 & $\mathrm{P}$ & $\mathrm{D}$ & $\mathrm{F}$ \\
\hline AD-3a & 363521116352501 & Davidson Well & $240 \mathrm{~s}$ & 16 & 120 & 250 & 15 & $\mathrm{P}$ & $\mathrm{D}$ & $\mathrm{F}$ \\
\hline \multirow[t]{2}{*}{$\mathrm{AD}-4 \mathrm{a}$} & 363428116234701 & Cooks East Well & $269 \mathrm{~s}$ & 13 & 147 & 213 & 12 & $\mathrm{P}$ & $\mathrm{D}$ & $\mathrm{F}$ \\
\hline & & & & & 238 & 286 & 12 & $\mathrm{P}$ & & \\
\hline AD-5 & 363310116294001 & USBLM Well & $348 \mathrm{~s}$ & 12 & $\mathrm{U}$ & $\mathrm{U}$ & $\mathrm{U}$ & $\mathrm{U}$ & M & $\mathrm{F}$ \\
\hline AD-6 & 363213116133800 & Tracer Well 3 & $678 \mathrm{~s}$ & 9 & 620 & 807 & 6 & $\mathrm{X}$ & $\mathrm{J}$ & $\mathrm{C}$ \\
\hline AD-7a & 363009116302702 & Blackman Well & 210 & 7 & $\mathrm{U}$ & $\mathrm{U}$ & $\mathrm{U}$ & $\mathrm{U}$ & $\mathrm{O}$ & $\mathrm{F}$ \\
\hline AD-8 & 362929116085701 & Cherry Patch Well & $215 \mathrm{~s}$ & 15 & $\mathrm{U}$ & $\mathrm{U}$ & $\mathrm{U}$ & $\mathrm{U}$ & M & $\mathrm{F}$ \\
\hline \multirow[t]{3}{*}{ AD-9 } & 362848116264201 & Gilgans North Well & $396 \mathrm{~s}$ & 13 & 60 & 90 & 12 & $\mathrm{P}$ & $\mathrm{D}$ & $\mathrm{F}$ \\
\hline & & & & & 154 & 244 & 12 & $\mathrm{P}$ & & \\
\hline & & & & & 245 & 396 & 15 & $\mathrm{X}$ & & \\
\hline AD-10 & 362525116274301 & NA-9 Well & 1,090 & 2 & 1,063 & 1,066 & 2 & $\mathrm{~S}$ & $\mathrm{D}$ & $\mathrm{F}$ \\
\hline AD-11 & 361954116181201 & GS-3 Well & 2,000 & 2 & 1,969 & 1,979 & 2 & $\mathrm{~S}$ & $\mathrm{D}$ & $\mathrm{F}$ \\
\hline AD-12 & 362014116133901 & GS-1 Well & 1,580 & 2 & 1,549 & 1,559 & 2 & $\mathrm{~S}$ & $\mathrm{D}$ & $\mathrm{F}$ \\
\hline $\mathrm{AD}-13$ & 361724116324201 & S-1 Well & 2,000 & 2 & 1,969 & 1,979 & 2 & $\mathrm{~S}$ & $\mathrm{D}$ & $\mathrm{F}$ \\
\hline
\end{tabular}


Table 2. Well-completion data at monitoring sites in Yucca Mountain region-Continued

\begin{tabular}{|c|c|c|c|c|c|c|c|c|c|c|}
\hline \multirow{3}{*}{$\begin{array}{c}\text { Site } \\
\text { number } \\
\text { (fig. 1) }\end{array}$} & \multirow{3}{*}{$\begin{array}{l}\text { U.S. Geological } \\
\text { Survey site } \\
\text { identification }\end{array}$} & \multirow{3}{*}{ Site name } & \multirow{3}{*}{$\begin{array}{l}\text { Accessible } \\
\text { well depth } \\
\text { (feet below } \\
\text { land } \\
\text { surface) }\end{array}$} & \multirow{3}{*}{$\begin{array}{l}\text { Casing } \\
\text { diameter } \\
\text { at land } \\
\text { surface } \\
\text { (inches) }\end{array}$} & \multicolumn{4}{|c|}{ Open interval } & \multirow{3}{*}{$\begin{array}{l}\text { Data } \\
\text { source }\end{array}$} & \multirow{3}{*}{$\begin{array}{c}\text { Contributing } \\
\text { units }\end{array}$} \\
\hline & & & & & \multicolumn{2}{|c|}{$\begin{array}{l}\text { Feet below } \\
\text { land surface }\end{array}$} & \multirow{2}{*}{$\begin{array}{l}\text { Diameter } \\
\text { (inches) }\end{array}$} & \multirow{2}{*}{ Type } & & \\
\hline & & & & & Top & Bottom & & & & \\
\hline AD-14 & 361817116244701 & Death Valley Jct Well & $225 \mathrm{~s}$ & 12 & 160 & 200 & 12 & $S$ & $\mathrm{D}$ & $\mathrm{F}$ \\
\hline \multirow[t]{2}{*}{ AM-1 } & 362858116195301 & Rogers Spring Well & $202 \mathrm{~s}$ & 16 & 100 & 240 & 12 & $\mathrm{P}$ & $\mathrm{D}$ & $\mathrm{F}$ \\
\hline & & & & & 240 & 420 & 16 & $\mathrm{X}$ & & \\
\hline \multirow[t]{3}{*}{ AM-2 } & 362755116190401 & Five Springs Well & $123 \mathrm{~s}$ & 14 & 0 & 100 & 13 & $\mathrm{P}$ & $\mathrm{D}$ & $\mathrm{C}$ \\
\hline & & & & & 100 & 140 & 14 & $X$ & & \\
\hline & & & & & 468 & 818 & $\mathrm{U}$ & $\mathrm{X}$ & & \\
\hline AM-3 & 362555116205301 & Garners Well & $202 \mathrm{~s}$ & 9 & 140 & 180 & 8 & $\mathrm{P}$ & $\mathrm{O}$ & $\mathrm{F}$ \\
\hline AM-5 & 362529116171100 & Devils Hole Well & $200 \mathrm{~s}$ & 16 & 48 & 248 & 16 & $\mathrm{P}$ & $\mathrm{D}$ & $\mathrm{F}$ \\
\hline AM-6 & 362432116165701 & Point of Rocks North Well & 500 & 16 & 139 & 500 & 16 & $\mathrm{P}$ & $\mathrm{D}$ & $\mathrm{F}$ \\
\hline \multirow[t]{2}{*}{ AM-7 } & 362417116163600 & Point of Rocks South Well & $586 \mathrm{~s}$ & 14 & 132 & 467 & 14 & $\mathrm{P}$ & $\mathrm{D}$ & $\mathrm{C}$ \\
\hline & & & & & 468 & 818 & $\mathrm{U}$ & $\mathrm{X}$ & & \\
\hline DV -3 & 362230116392901 & Travertine Point 1 Well & $650 \mathrm{~s}$ & 5 & 100 & 970 & 5 & $\mathrm{X}$ & $\mathrm{D}$ & $\mathrm{C}$ \\
\hline
\end{tabular}

\section{U.S. Geological Survey Site Identification}

Sites are identified by the standard U.S. Geological Survey identification number, which is based on an initial determination of latitude and longitude of the site. The site identification serves as a unique identification number in files and data bases of the USGS and indicates the approximate geographic location of each site. The identification consists of 15 digits: the first 6 digits denote the degrees, minutes, and seconds of latitude; the next 7 digits denote degrees, minutes, and seconds of longitude; and the last 2 digits (assigned sequentially) identify the site within a 1-second grid. For example, site 363530116021401 is at approximately $36^{\circ} 35^{\prime} 30^{\prime \prime} \mathrm{N}$ latitude and $116^{\circ} 02^{\prime} 14^{\prime \prime} \mathrm{W}$ longitude, and it is the first site recorded in that 1 -second grid. Even if a more precise latitude and longitude are subsequently determined, the site identification number remains unchanged. Latitude and longitude shown for a site, therefore, are the most accurate locators.

\section{Local Site Number}

The local site number (table 1) is based on an index of hydrographic areas (Rush, 1968; Harrill and others, 1988) and on the rectangular subdivision of public lands referenced to the Mount Diablo base line and meridian for sites in Nevada, or San Bernadino base line and meridian for sites in California. Numbering conventions differ depending on whether a site is in Nevada or California.

For sites in Nevada, each local number consists of four units separated by spaces: The first unit is the hydrographic area number; the second unit is the township, preceded by an $\mathrm{S}$ to indicate location south of the base line; the third unit is the range, preceded by an $\mathrm{E}$ to indicate location east of the meridian; and the fourth unit consists of the section number and letters designating the quarter section, quarter-quarter section and so on (A, B, C, and D, indicate the northeast, northwest, southwest, and southeast quarters, respectively), followed by a number indicating the sequence in which the well was recorded. For example, site 230 S18 E51 34CBD1 is in the Amargosa Desert (hydrographic area 230) and is the first site recorded in the southeast quarter of the northwest quarter of the southwest quarter of section 34, township 18 south, range 51 east, Mount Diablo base line and meridian.

For sites in California, the local number consists of the hydrographic area number followed by three spaces. The next 10 characters indicate the township and location north or south of the baseline, the range 
and location east or west of the meridian, and the section number. The letter following the section number designates the 40-acre subdivision of the section in which the site is located (U.S. Geological Survey, 1996). The final letter indicates that the location is referenced to the San Bernardino (S) base line and meridian and is preceded by a 3-digit number (for wells) or an "S" and 2-digit number (for springs) indicating the sequence in which the site was recorded. For example, site 230 025N005E14M001S is a well in the Amargosa Desert (hydrographic area 230) and is the first site recorded in the 40-acre subdivision designated $\mathrm{M}$ of section 14, township 25 north, range 5 east, San Bernardino base line and meridian.

\section{Data Type}

Data type (table 1) identifies the types of data (water level and discharge) presented for each site. Ground-water-level data are in tables 5-7 and groundwater-discharge data are in table 8.

\section{Accessible Well Depth}

Accessible well depth (table 2) is the measurable depth to the bottom of the well. The drilled depth may be greater than the accessible depth of the well due to modifications of the well, obstructions, or accumulation of sediment at the bottom of the well. The depth of each well was measured by USGS (depths noted with "s") or was reported by other data sources. The USGS measured depths less than 1,000 ft by "sounding" the bottom of the well with weighted steel or electric tapes.

\section{Top and Bottom of Open Interval}

Open intervals (table 2) are parts of the well that are open to the surrounding lithologic intervals and allow water to enter the well. An uncased section of a well is considered an open interval in this report.

\section{Type of Open Interval}

Type of open interval (table 2) is a physical description of the open intervals of a borehole. The types of openings are perforated or slotted casing, screened casing, and open hole with no casing.

\section{Data Source}

Data sources (table 2) are organizations or publications from which information on depth of well, open interval, and type of opening was obtained. Drillers' logs or records are filed with the Nevada Division of Water Resources (NDWR) or maintained by the well owner. Fenix and Scisson, Inc., and Raytheon Services Nevada were contractors for DOE and maintained a summary of well-construction information for selected wells in the area. Publications are USGS reports written for DOE as part of cooperative studies associated with weapons-testing hydrology programs (Thordarson and others, 1967; Johnston, 1968) or Yucca Mountain site-characterization studies (Robison and others, 1988).

\section{Contributing Lithologic Units}

Contributing units (table 2) are the principal lithologic intervals at the site that yield water to the well. For purposes of this report, contributing units are one or a combination of four general types. Wells characterized as having a contributing unit of carbonate or volcanic rock are wells with open intervals in those consolidated rocks. In and near the Amargosa Desert, wells characterized as having a contributing unit of valley fill are those with open intervals in unconsolidated valley-filling materials, including lakebed deposits. Wells with open intervals in clastic rock (including argillite, limy sandstones and siltstones, or silty, sandy, and shaley limestones) are characterized as having a contributing unit of undifferentiated sedimentary rock.

Robison and others (1988) describe the contributing units at sites CF-2, JF-1, JF-2, JF-2a, and J-13. McKinley and others (1991) describe the contributing units for sites J-11, J-12, MV-1, AD-4a, AD-5, AD-6, AD-8, and AM-4. Thordarson and others (1967) describe the contributing unit at site RV-1. Dudley and Larson (1976) describe the contributing units for sites AM-2, AM-5, and AM-7. Contributing-unit data are not available from listed data sources for some wells; the contributing units indicated for those wells are derived from driller's logs or well-completion reports that describe geology in the boreholes, open intervals in the wells, and measurements of depth to water. 
Contributing units for springs (fig. 1) indicate sources of water discharged at the sites. Winograd and Thordarson (1975, p. C75-C97) describe sources of discharge at sites AM-1a, AM-5a, AM-8, and DV-1. McKinley and others (1991) describe the source of discharge at site DV-2.

\section{DATA-COLLECTION PROCEDURES AND EQUIPMENT}

Water-level and discharge data for monitoring sites were compiled from available sources, from USGS files and data bases, and from measurements made by U.S. Geological Survey Environmental-Monitoring Program (USGS-EMP) personnel. Data-collection procedures and equipment used by USGS-EMP are described in detail, and equipment used by other sources are described briefly. Water-use data are compiled from available sources as described in the section "Ground-Water Withdrawal Data."

\section{Periodic Water-Level Data}

Periodic water-level measurements in table 5 are generally made during site visits, using one of the methods described in the section "Water-Level Measurements." Supplemental information, including land-surface altitude, height of measurement point, method of measurement, site status, and source of data, are also listed in table 5.

\section{Land-Surface Altitude and Height of Measurement Point}

Land-surface altitude and height of the measurement point (MP) above (or depth below) land surface are included with periodically collected data in table 5 . Land-surface altitude is a representative altitude of land at or near the site. An exception is site AM-4 (Devils Hole), where the land-surface altitude represents the altitude of the measurement point (a bolt fastened to the south wall of the fissure) that is not referenced to land surface. Land surveys were made by USGS personnel at the monitoring sites to determine the altitudes of land surface or the MP.

Heights of MP's for sites in Amargosa Desert (except AM-4), Death Valley, and Rock Valley were determined by measuring the distance of the MP above (or depth below) a representative point on the land surface at or near the well. The altitude of the MP was determined during the USGS land survey, and land-surface altitude was computed by adding or subtracting the MP height from the surveyed MP altitude.

At sites JF-1, JF-2, JF-2a, and J-13, USGS land surveys verified previously reported land-surface and MP altitudes. At sites CF-2, J-11, and J-12, USGS land surveys verified the previously reported land-surface altitudes and determined the MP altitude by adding the height of the MP to the land-surface altitude. At sites CF-1a, and MV-1, USGS land surveys determined the land surface and MP altitudes. The height of the MP is the difference between the MP altitude and landsurface altitude. Land-surface altitudes are reported to the nearest tenth of a foot.

\section{Depth to Water and Altitude of Water Surface}

Depth to water, in feet below land surface, is computed as the measured depth to water below the MP minus the height of the MP above land surface at the well. The altitude of water surface is the depth to water subtracted from the altitude of land surface and is reported to the nearest tenth of a foot. At site AM-4, the depth to water represents depth below the MP and the altitude is the depth to water subtracted from the altitude of the bolt.

\section{Water-Level Measurements}

Periodic water-level measurements made by USGS-EMP personnel were completed using the procedures and equipment described in the following sections. Measurement methods by other sources also are briefly described.

\section{Calibrated Electric Tape}

USGS-EMP personnel used two calibrated 1,000-ft electric tapes and one calibrated 2,000-ft electric tape during 1999. Each tape was marked with a unique identifier (YMP-11, YMP-13 and PRT-3) for quality-assurance purposes. The electric tapes were calibrated using steel tapes. At depths less than $500 \mathrm{ft}$, the electric tapes were calibrated using a steel tape maintained by USGS-EMP personnel and identified as the 500-ft reference steel tape \#1. At depths greater than $500 \mathrm{ft}$, the electric tapes were calibrated using the U.S. Geological Survey Site Characterization Project (USGS-SCP) 2,600-ft calibrated steel tape identified 
by USGS-SCP as Chain \#3. Selected calibration data for the electric tapes are summarized in table 3. Calibration data for tapes YMP-13 and PRT-3 presented in Locke (2001, table 3 ) are not repeated in this report.

The corrections to the USGS-SCP calibrated steel tape account for mechanical stretch and thermal expansion of the tape. No corrections were necessary for the USGS-EMP 500-ft reference steel tape \#1 because mechanical stretch and thermal expansion of the tape are considered negligible at the depths to water measured. The correction factors for the electric tapes are the difference between the corrected steeltape measurement and the uncorrected electric-tape measurement.

A summary of correction factors applied to USGS-EMP electric tapes for 1999 is listed in table 4. The correction factor is used to adjust depth-to-water measurements made with an electric tape to account for mechanical stretch, incorrect markings, and changes to the physical condition of the tape. The measurement period represents the time during which the correction factors were applied. Applied correction factors for 1999 usually are averages of individual correction factors; individual correction factors include discrete corrections presented in table 3 of this report and applied factors listed in table 4 of previous reports on selected ground-water data for the Yucca Mountain Region.

Applied correction factors for specific depth ranges are based on measurement periods in which differences of $0.05 \mathrm{ft}$ or less are calculated between (1) the average of individual correction factors within a particular range of depths to water and (2) the individual correction factors within that range. For example, the $-0.53 \mathrm{ft}$ applied correction factor for tape PRT-3 (in the depth range 1,100-1,299 ft) is an average of the individual correction factors $-0.54 \mathrm{ft}$, $-0.50 \mathrm{ft}$, and $-0.54 \mathrm{ft}$ (table 3 and Locke, 2001, table 3). When an applied correction factor for a depth range cannot be derived accordingly, presumably due to an indeterminate change in the physical condition of a tape, the applied correction factor for a measurement period is calculated from a linear proration of factors determined for successive calibrations. Linear prorations of correction factors are applied by time and are represented by listing the beginning and ending factors separated by "to" in table 4 .

Applied correction factors also may be based on measurement periods in which differences of $0.05 \mathrm{ft}$ or less are calculated between (1) an average of factors for specific depth ranges (as derived above) and (2) all individual correction factors within those ranges. For example, the $-0.04 \mathrm{ft}$ applied correction factor for tape YMP-13 (in the 100-299 ft and 300-499 ft depth ranges in table 4) is an average of the $-0.02 \mathrm{ft}$ and $-0.05 \mathrm{ft}$ factors determined for each depth range and is within $0.05 \mathrm{ft}$ of the individual correction factors $-0.03,-0.02,-0.02,-0.03,-0.05$, and -0.08 (table 3 and Locke, 2001, table 3).

Calibrated electric tapes were used at wells when frequent repetitive measurements were required due to fluctuating water levels, depths to water were greater than $500 \mathrm{ft}$, or wet conditions inside a well which prevented measurements using chalked steel tapes. Electric-tape measurements are made by lowering the end of the tape to the water surface until a signal is activated when a probe on the end of the tape contacts the water. The tape is raised and lowered slowly until the exact point of contact is located. While holding the tape on the MP, the depth to water below the MP is read from markings on the tape. At least two measurements are made during each site visit, and supplemental measurements are made if those two measured depths differ by more than $0.05 \mathrm{ft}$. If supplemental measurements indicate the difference is due to rapidly changing water levels, the measured depths and appropriate site status are recorded. Measurements using calibrated electric tapes are indicated by method "V" in table 5 .

An example calculation of depth to water below land surface for a site, using USGS-EMP calibrated electric tape PRT-3, is shown below:

Location: JF-3

Date: February 3, 1999

Time: 0831

Tape ID: PRT-3

Correction factor: $-0.31 \mathrm{ft}$ (for depths from 700 to $899 \mathrm{ft}$ )

Depth below MP $712.75 \mathrm{ft}$

Correction factor $-.31 \mathrm{ft}$

Corrected depth below MP $712.44 \mathrm{ft}$ Height of MP above land surface $-2.27 \mathrm{ft}$ Depth to water below land surface

$710.17 \mathrm{ft}$

Water-level measurements were made with electric tapes by the U.S. Fish \& Wildlife Service (USFWS) at sites AM-1, AM-5, AM-6, and AM-7 and by the Nevada Division of Water Resources (NDWR) at sites AD-7a and AD-9. All these measure- 
Table 3. Electric-tape calibration data used to derive correction factors for calendar year 1999. Calibration data used to derive correction factors but not listed herein are presented in the previous report (Locke, 2001) on selected ground-water data for Yucca Mountain region

[USGS-EMP ST1, U.S. Geological Survey Environmental-Monitoring Program 500-ft reference steel tape \#1; USGS-SCP ST3, U.S. Geological Survey Site-Characterization Project Chain \#3 (steel tape); YMP-11, YMP-13, 1,000-ft electric tapes; PRT-3, 2,000-ft electric tape]

\begin{tabular}{|c|c|c|c|c|c|}
\hline \multirow[b]{2}{*}{ Date } & \multirow{2}{*}{$\begin{array}{c}\text { Site } \\
\text { number } \\
\text { (fig. 1) }\end{array}$} & \multirow[b]{2}{*}{ Tape used } & \multicolumn{2}{|c|}{ Depth below measuring point } & \multirow{2}{*}{$\begin{array}{l}\text { Correction } \\
\text { (feet) }\end{array}$} \\
\hline & & & $\begin{array}{l}\text { Uncorrected } \\
\text { (feet) }\end{array}$ & $\begin{array}{l}\text { Corrected } \\
\text { (feet) }\end{array}$ & \\
\hline \multirow[t]{2}{*}{ 01-20-99 } & $\mathrm{CF}-2$ & USGS-SCP ST3 & 604.92 & 604.92 & 0.00 \\
\hline & & YMP-11 & 605.03 & 604.92 & -.11 \\
\hline \multirow[t]{2}{*}{ 01-21-99 } & $\mathrm{J}-12$ & USGS-SCP ST3 & 744.16 & 744.16 & .00 \\
\hline & & YMP-11 & 744.26 & 744.16 & -.10 \\
\hline \multirow[t]{8}{*}{ 08-17-99 } & AD-5 & USGS-EMP ST1 & 128.24 & 128.24 & .00 \\
\hline & & YMP-13 & 128.26 & 128.24 & -.02 \\
\hline & AD-13 & USGS-EMP ST1 & 375.42 & 375.42 & .00 \\
\hline & & YMP-13 & 375.47 & 375.42 & -.05 \\
\hline & $\mathrm{CF}-2$ & USGS-SCP ST3 & 605.09 & 605.09 & .00 \\
\hline & & YMP-11 & 605.18 & 605.09 & -.09 \\
\hline & & YMP-13 & 605.23 & 605.09 & -.14 \\
\hline & & PRT-3 & 605.36 & 605.09 & -.27 \\
\hline \multirow[t]{8}{*}{ 08-19-99 } & $\mathrm{J}-12$ & USGS-SCP ST3 & 744.08 & 744.08 & .00 \\
\hline & & YMP-11 & 744.18 & 744.08 & -.10 \\
\hline & & YMP-13 & 744.24 & 744.08 & -.16 \\
\hline & & PRT-3 & 744.43 & 744.08 & -.35 \\
\hline & $\mathrm{JF}-2$ & USGS-SCP ST3 & 996.21 & 996.21 & .00 \\
\hline & & PRT-3 & 996.82 & 996.21 & -.61 \\
\hline & JF-1 & USGS-SCP ST3 & $1,161.94$ & $1,161.94$ & .00 \\
\hline & & PRT-3 & $1,162.44$ & $1,161.94$ & -.50 \\
\hline \multirow[t]{8}{*}{$01-10-00$} & AD-5 & USGS-EMP ST1 & 128.58 & 128.58 & .00 \\
\hline & & YMP-13 & 128.60 & 128.58 & -.02 \\
\hline & AD-13 & USGS-EMP ST1 & 374.16 & 374.16 & .00 \\
\hline & & YMP-13 & 374.24 & 374.16 & -.08 \\
\hline & $\mathrm{CF}-2$ & USGS-SCP ST3 & 604.98 & 604.98 & .00 \\
\hline & & YMP-11 & 605.10 & 604.98 & -.12 \\
\hline & & YMP-13 & 605.13 & 604.98 & -.15 \\
\hline & & PRT-3 & 605.26 & 604.98 & -.28 \\
\hline \multirow[t]{8}{*}{$01-11-00$} & $\mathrm{~J}-12$ & USGS-SCP ST3 & 743.70 & 743.70 & .00 \\
\hline & & YMP-11 & 743.80 & 743.70 & -.10 \\
\hline & & YMP-13 & 743.88 & 743.70 & -.18 \\
\hline & & PRT-3 & 744.05 & 743.70 & -.35 \\
\hline & JF-2 & USGS-SCP ST3 & 995.87 & 995.87 & .00 \\
\hline & & PRT-3 & 996.56 & 995.87 & -.69 \\
\hline & JF-1 & USGS-SCP ST3 & $1,161.66$ & $1,161.66$ & .00 \\
\hline & & PRT-3 & $1,162.20$ & $1,161.66$ & -.54 \\
\hline
\end{tabular}


Table 4. Applied correction factors for electric tapes used during calendar year 1999. Correction factors for 1999 are based on calibration data listed in table 3 of this report and data listed in table 4 of the previous report on selected ground-water data for Yucca Mountain Region

[Symbol: —, no measurements made for given depth-to-water range during period specified]

\begin{tabular}{|c|c|c|c|c|c|c|c|c|}
\hline \multirow{2}{*}{ Tape } & \multicolumn{2}{|c|}{ Measurement period } & \multicolumn{6}{|c|}{ Correction factors for indicated depth ranges (feet) } \\
\hline & Start & End & 100-299 & $300-499$ & $500-699$ & 700-899 & $900-1,099$ & $1,100-1,299$ \\
\hline PRT-3 & 01-26-99 & 08-19-99 & - & - & -0.31 & -0.31 & -0.59 & -0.53 \\
\hline PRT-3 & 08-20-99 & $01-11-00$ & - & - & -.31 & -.31 & -.59 to -.69 & -.53 \\
\hline YMP-11 & $01-21-99$ & $01-11-00$ & - & - & - & -.10 & - & - \\
\hline YMP-13 & 01-22-99 & $01-11-00$ & -0.04 & -0.04 & -.15 & -.15 & - & - \\
\hline
\end{tabular}

ments are listed with method "T" in table 5. Personnel from another USGS Nevada District program made a measurement at AD-1 with an electric tape.

\section{Steel Tape}

In 1999, USGS-EMP personnel maintained one 500-ft steel tape as a reference tape and used three field steel tapes (one 500-ft and two 300-ft tapes) for routine measurements. The steel tapes are uniquely marked (reference steel tape \#1, ST-5, ST-6, and ST-7). The steel tapes were checked against the reference tape at several depths to water to verify their accuracy. No corrections to the measurements made with these steel tapes were needed in 1999.

General procedures for using 300- and 500-ft steel tapes are to (1) chalk the bottom section of the tape, (2) lower the tape into the well until part of the chalked section is below the water surface, (3) hold the tape on the MP and record the "hold" reading, (4) raise the end of the tape to the surface, observing the "cut" (top of the wet part of the chalked tape), (5) record the reading of the cut, (6) calculate the depth to water below the MP by subtracting the "cut" reading from the "hold" reading, and (7) calculate the depth to water below land surface by subtracting the height of the MP from the depth to water below MP. USGS-EMP personnel make a minimum of two measurements during each site visit to verify the initial measurement. Supplemental measurements are made if the two measured depths differ by more than $0.05 \mathrm{ft}$. If supplemental measurements indicate the difference is due to fluctuating water levels, the measured depths and appropriate site status are recorded.

USGS-SCP personnel made water-level measurements using calibrated steel tapes at sites CF-2, JF-1, JF-2, JF-2a, J-13, J-11, and J-12. Descriptions of the steel tapes, applicable corrections, and procedures used by USGS-SCP for making steel-tape measurements are given by Robison and others (1988, p. 6-11), Gemmell (1990, p. 8-12), O’Brien (1991, p. 8-13), O'Brien and others (1995, p. 4-7), Graves and others, (1996, p. 5-10), Tucci, O'Brien, and Burkhardt (1996, p. 5-8), and Graves and Goemaat (1998, p. 5-11). USGS-SCP steel-tape measurements were compiled from information provided by USGSSCP (R.P. Graves and C.S. Savard, U.S. Geological Survey, written communs., 1999 and 2000). Corrected depth-below-MP measurements were provided by USGS-SCP personnel and converted to depth below land surface by USGS-EMP personnel by subtracting the height of the MP above land surface.

Water-level measurements were made with steel tapes by personnel from the NDWR at sites AD-7a and AD-9. All measurements using steel tapes are listed with method " $\mathrm{S}$ " in table 5.

\section{Other}

Site AD-14 was measured by personnel from another USGS Nevada District program with a ruled tape. This measurement is listed with method " $\mathrm{N}$ " in table 5 . 


\section{Continual Water-Level Data}

Two sites, JF-3 and AD-6, are instrumented by USGS-EMP to continually record ground-water level, atmospheric pressure, and battery voltage at 15 -minute intervals. Instrumentation includes a gaged (vented) pressure sensor installed below the water surface, a barometer, and a data logger. Recorded data are processed to produce data on continual depth to water, atmospheric pressure, battery voltage, and daily average depth to water.

The pressure sensors at sites JF-3 and AD-6 transmit data to the data logger in pounds per square inch, which varies with the height of the water above the sensor. The range of output is 0 to $5.000 \mathrm{lb} / \mathrm{in}^{2}$, which corresponds to a theoretical range of 0 to $11.53 \mathrm{ft}$ of water above the pressure sensor. The general steps for installing and calibrating pressure sensors and processing pressure-sensor data are as follows:

1. Depth to water below MP is measured with a calibrated steel or electric tape and recorded on a field sheet. If a calibrated electric-tape measurement is made, a correction factor is applied. Depth to water below MP is used for pressure-sensor calibration, rather than depth to water below land surface, because a fixed point of reference is required.

2. The pressure-sensor cable is connected to a data logger and the sensor is lowered down the well until a substantial change in readings indicates the water surface has been reached.

3. The sensor is lowered to a set point and the pressure-sensor readings are recorded after the sensor equilibrates. The set-point depth of the sensor is determined by adding the depth-towater measurement to the depth at which the sensor is installed below the water surface. For example, if the depth-to-water is $710 \mathrm{ft}$ below the MP and the sensor is installed $5 \mathrm{ft}$ below the water surface, the set-point depth is $715 \mathrm{ft}$. The sensor cable is marked or tagged at the MP. This mark or tag is used for making measurements when the pressure sensor is raised or lowered.

4. Following installation, the sensor is calibrated for a range of depths that spans the anticipated range of water-level fluctuation. Water-level fluctuations (differing depths to water below the MP) are simulated by raising and lowering the pressure sensor. Raising the sensor $1 \mathrm{ft}$ above the set point will decrease the amount of submergence of the pressure sensor by $1 \mathrm{ft}$, thereby simulating a $1 \mathrm{ft}$ increase in depth to water. For example, if the depth to water is $710 \mathrm{ft}$ below the MP (step 1) and the sensor is raised $1 \mathrm{ft}$, the simulated depth to water below the MP would be $711 \mathrm{ft}(710+1=711 \mathrm{ft})$. Lowering the sensor $1 \mathrm{ft}$ below the set point will increase the amount of submergence of the pressure sensor by $1 \mathrm{ft}$, thereby simulating a $1 \mathrm{ft}$ decrease in depth to water. If the depth to water is $710 \mathrm{ft}$ below the MP and the sensor is lowered $1 \mathrm{ft}$, the simulated depth to water below the MP would be $709 \mathrm{ft}(710-1=$ $709 \mathrm{ft}$ ).

The sensor is raised and lowered at 1/2-, 1-, or 2 -ft intervals above or below the set point. The tag or marking placed on the sensor cable at the set point (step 3) provides a reference for measuring the distance the sensor is raised or lowered. After the sensor output has stabilized at each interval, the time, pressure readings from the data logger (in pounds per square inch), distance of sensor above or below the set point, and simulated depth to water are recorded on the field sheet. The sensor cable is marked or tagged at the measured intervals and later used for calibration checks.

5. Upon completion of pressure-sensor calibration, the sensor is returned to the set point and the time and pressure readings from the data logger are recorded on the field sheet. Another water-level measurement is made with a calibrated steel or electric tape and recorded to check for fluctuation of the water level during installation or calibration of the sensor.

6. Data recorded while calibrating the sensor are used to develop a regression equation to convert pressure readings to water level below MP. The pressure readings from the data logger and corresponding simulated depths below the MP are regressed using pressure (in pounds per square inch) as the independent variable and depth below the MP (in feet) as the dependent variable. 
The applicable period for utilizing a particular regression equation (to convert pressure readings to depth to water below the MP) generally corresponds with calibrations at the beginning and ending of that period. In some cases, however, the applicable period for a regression equation does not correspond with successive calibrations; a period is selected that minimizes differences between reference measurements made during site visits and computed water levels at dates intermediate to the two calibrations.

Water-level measurements are made with a calibrated steel or electric tape when a continual monitoring site is visited. The pressure-sensor reading is recorded by the data logger at the time of the measurement. The reading is converted to depth to water, using the established regression equation, and recorded on a field sheet as computed water level. The steel tape or electric tape water-level measurement is used as a reference measurement and is compared to the computed value. Any difference between the reference measurement and computed value is applied as a correction to the continual record by linearly prorating the difference with time between consecutive visits to account for drift in pressure-sensor output.

Data are retrieved from the data logger using a portable computer, transferred to the USGS National Water-Information System (NWIS), and processed using data-base programs. The pressure-sensor data are converted to depths below land surface and stored in the data base. Daily average values are computed from the continual data and stored in the data base. Daily average depth-to-water values are used to compute daily average water-level altitudes, which also are stored in the data base.

\section{Pressure-Sensor System at Site JF-3}

Instrumentation has been installed at JF-3 since May 28, 1992, to continually collect water-level data every 15 minutes. The pressure sensor used to collect data in 1999 was installed on February 4, 1997. The sensor was recalibrated on February 3, 1999, and a new regression equation was developed: depth to water below land surface $(\mathrm{ft})=(-2.346 \times$ pressure reading $)+714.288(\mathrm{ft})$. The coefficient of determination of the regression equation was 1.0. The equation was based on 12 points between pressure transducer and tape-down measurements. Pressure readings stored in the data base from January 1 to February 3, 1999, were converted to depth below land surface using this equation to minimize differences between reference measurements and computed water levels. Differences between reference measurements made with calibrated electric tapes and computed water levels, based on conversion of pressure readings during that period, ranged from $-0.06 \mathrm{ft}$ (January 25) to $-0.08 \mathrm{ft}$ (February 3 ).

On February 1, 2000, the sensor was recalibrated and a new regression equation was developed: depth to water below land surface $(\mathrm{ft})=(-2.326 \times$ pressure reading $)+714.152(\mathrm{ft})$. The coefficient of determination of the regression equation was 1.0. The equation was based on 11 points between pressure transducer and tape-down measurements. This equation was used from February 3 to December 31, 1999, thereby minimizing corrections to computed water levels. The differences between a reference measurement made with a calibrated electric tape and a computed water level ranged from $0.01 \mathrm{ft}$ (April 6) to $-0.05 \mathrm{ft}$ (October 5, 1999).

Depth-to-water measurements made with calibrated electric tapes during 1999 (table 5) ranged from $709.91 \mathrm{ft}$ (January 25) to $710.28 \mathrm{ft}$ (July 7) below land surface. The daily average water levels during 1999 (table 6) ranged from $709.68 \mathrm{ft}$ (December 31) to $710.70 \mathrm{ft}$ (February 11) below land surface.

\section{Pressure-Sensor System at Site AD-6}

Instrumentation has been installed at AD-6 since July 29, 1992, to continually collect water-level data every 15 minutes. The pressure sensor used to collect data in 1999 was installed on February 6, 1997. The sensor was recalibrated on February 3, 1999, and a new regression equation was developed: depth to water below land surface $(\mathrm{ft})=(-2.332 \times$ pressure reading $)+46.722(\mathrm{ft})$. The coefficient of determination of the regression equation was 1.0. The equation was based on 11 points between pressure transducer and tape-down measurements. Pressure readings stored in the data base from January 1 to December 31, 1999, were converted to depth below land surface using this equation to minimize differences between reference measurements and computed water levels. Differences between reference measurements made with steel tapes and computed water levels, based on the conversion of pressure readings during that period, ranged from $0.00 \mathrm{ft}$ (January 28, April 6, May 3, September 1, December 14) to -0.03 ft (July 3). 
On February 18, 2000, the pressure sensor was recalibrated and a new regression equation was developed: depth to water below land surface $(\mathrm{ft})=$ $(-2.322 \times$ pressure reading $)+46.676(\mathrm{ft})$. The coefficient of determination of the regression equation was 1.0. The equation was based on nine points between pressure transducer and tape-down measurements. This equation was not used to convert any pressure readings made in 1999.

Depth-to-water measurements made with steel tapes during 1999 (table 5) ranged from $41.50 \mathrm{ft}$ (May 3) to $41.82 \mathrm{ft}$ (December 14) below land surface. The daily average water levels during 1999 (table 7) ranged from $41.45 \mathrm{ft}$ (April 21) to $41.86 \mathrm{ft}$ (February 11) below land surface.

\section{Ground-Water Discharge Data}

Measurements of ground-water discharge were collected and compiled for five springs and one flowing well (AM-2). Four of the sites, AM-1a, AM-2, AM-5a, and AM-8, are in the Ash Meadows springdischarge area of the Amargosa Desert. The other two sites, DV-1 and DV-2, are in Death Valley. Discharge measurements were made by NPS, USFWS, and USGS-EMP. Periodic and monthly mean discharge data were determined by the use of current meters, flumes, and volumetric techniques.

The most commonly used method for measuring discharge, indicated by method " $\mathrm{C}$ " in table 8 , was the vertical-axis current meter. This method is used to determine the average velocity of a partial section within a channel cross section. The average velocity within the partial section times the area of the partial section equals the discharge of that section. The summation of the discharges for all the partial sections is the total discharge in the channel. This method is described in more detail by Buchanan and Somers (1969).

Some discharge values were determined by measuring the depth of water inside a flume. The depth, or stage, is compared to an applicable stage-discharge relation for the flume to determine discharge. This method, indicated by method " $F$ " in table 8 , was used for site AM-1a. Determining discharges by the use of flumes is further described by Kilpatrick and Schneider (1983). Where an instrument has been installed to continually record stage in a flume, mean discharges can be computed for specific periods. This method is indicated in table 8 by method " $\mathrm{Z}$ " and was used for site DV-1, where monthly mean discharge (reported for the 15th of the month) was computed on the basis of daily data collected by NPS.

The volumetric method, indicated by method "V" in table 8, was used for measuring ground-water discharge from sites AM-2 and DV-2. A container was used to collect all discharge from the site while a stopwatch was used to determine the amount of time the discharge was collected. The container was positioned to collect the discharge and the stopwatch was started simultaneously. The container was removed, before it was overfilled, and the stopwatch was stopped simultaneously. The volume collected and elapsed time were determined; the discharge rate is the volume collected divided by the time. This procedure was repeated three times and an average rate was computed for each site visit.

The accuracy of the methods is directly related to the operational conditions of the equipment used and to the environmental conditions in which the equipment operated. Discharge values are reported to two significant figures. Discharge determined by all methods ranged from $0.90 \mathrm{gal} / \mathrm{min}$ at site DV-2 to 3,000 gal/min at site AM-5a for 1999 (table 8).

\section{Ground-Water Withdrawal Data}

Estimated ground-water withdrawals from wells for calendar year 1999 are presented in table 9 and historical annual withdrawals are presented in figures 10 and 11 by hydrographic area within the Alkali Flat-Furnace Creek Ranch and the Ash Meadows ground-water subbasins. Total ground-water withdrawal was determined for the Amargosa Desert, Crater Flat, Jackass Flats, and Mercury Valley hydrographic areas. The Amargosa Desert spans both subbasins and is subdivided into two areas within the Ash Meadows ground-water subbasin.

Withdrawals were estimated from compiled data supplied by public agencies including DOE, USGS, and NDWR. Ground-water withdrawals also were compiled from information provided by Bechtel Nevada.

Estimated annual ground-water withdrawals are based solely on available data and may be underestimated. Only when most of the withdrawals for an area were available, was an estimate made. In figures 
10 and 11, the years that have no data reflect that an estimate could not be made, rather than an estimate of no ground-water withdrawal.

\section{Withdrawals from Alkali Flat-Furnace Creek Ranch Ground-Water Subbasin}

Withdrawals from the Amargosa Desert hydrographic area within the Alkali Flat-Furnace Creek Ranch ground-water subbasin were recompiled from ground-water pumpage inventories taken by NDWR. The pumpage inventories were for the entire Amargosa Desert during 1999, and include estimated withdrawals for irrigation, mining, quasi-municipal and commercial, and domestic uses. All reported withdrawals for mining use are from the Alkali Flat-Furnace Creek Ranch ground-water subbasin. Almost all reported withdrawals for irrigation (about 99.9 percent) and quasi-municipal and commercial uses (about 99.6 percent) in the Amargosa Desert are also from the Alkali Flat-Furnace Creek Ranch ground-water subbasin. Reported domestic use is based on the number and location of wells drilled for domestic purposes, as stored in data bases maintained by NDWR (Robert A. Coache, Nevada Division of Water Resources, oral commun., 2000); about 84.6 percent of all domestic use is from the part of the Amargosa Desert within this subbasin.

Withdrawals from Crater Flat were determined from totalizing flowmeters at Gexa Well 4 (about 1.6 mi northeast of site CF-1a), well Daisy PW-2 (about 1.8 mi northeast of site CF-1a), USW SD-6 (about 6.0 mi northeast of site CF-2), and site CF-3. Withdrawals from Gexa Well 4, well Daisy PW-2 and CF-3 are based on information from NDWR (Tim Wilson, Nevada Division of Water Resources, written commun., 2000). Withdrawals from well USW SD-6 are based on quarterly pumpage reports provided by DOE (Wendy Dixon and Scott Wade, U.S. Department of Energy, written communs., 1999 and 2000). Data on withdrawals from well USW VH-2 (about 1.5 mi northwest of site CF-2) were not available, although ground water is known to have been pumped from that well during 1999.

Withdrawals from Jackass Flats were determined from totalizing flowmeters at sites $\mathrm{J}-13, \mathrm{~J}-12$ and well UE-25c \#3 (about 2.5 mi northwest of site J-13). Withdrawals at sites $\mathrm{J}-13$ and $\mathrm{J}-12$ were recompiled from flowmeter readings supplied by Bechtel Nevada as part of the USGS Hydrologic Resources Management
Program (David B. Wood, U.S. Geological Survey, written commun., 2000). Withdrawals from well UE-25c \#3 are based on quarterly pumpage reports provided by DOE (Wendy R. Dixon and Scott A. Wade, U.S. Department of Energy, written communs., 1999 and 2000).

Withdrawals from Rock Valley are considered non-existent. The valley is within the Nevada Test Site, which limits public access and use. No DOE water supply wells are within the valley. Only one well (MV-1) is listed in the NDWR well data base and this well is not used.

\section{Withdrawals from Ash Meadows Ground-Water Subbasin}

Withdrawals from Mercury Valley were recompiled from flowmeter readings supplied by Bechtel Nevada for site MV-1 as part of the USGS Hydrologic Resources Management Program (David B. Wood, U.S. Geological Survey, written commun., 2000).

The Amargosa Desert within the Ash Meadows ground-water subbasin has been divided into two parts to provide information on withdrawals in the immediate vicinity of the environmentally sensitive Ash Meadows area; they are identified in table 9 and figure 11 as the Amargosa Desert (excluding Ash Meadows area) and the Amargosa Desert (Ash Meadows area). No withdrawals were reported for mining use from these two areas of the Amargosa Desert. Withdrawals for irrigation and quasi-municipal use in the Amargosa Desert (excluding Ash Meadows area) include withdrawals from two wells located in T. 17 S., R. 52 E. Withdrawals for quasi-municipal and commercial use from the Amargosa Desert (Ash Meadows area) include withdrawals from two wells located in T. 18 S., R. 50 E. Withdrawals for domestic use from the two areas of the Amargosa Desert were about 13.5 and 1.9 percent, respectively, of total reported domestic use in the entire Amargosa Desert hydrographic area during 1999; estimates of domestic use are based on the number and location of wells drilled for domestic purposes (as stored in data bases maintained by NDWR). 


\section{Quality Assurance}

Stringent quality assurance is done for all work pertaining to Yucca Mountain studies to establish adequate confidence in the reliability of data collection, processing, and reporting. In the context of this datacollection program, quality assurance is defined as all planned or systematic actions designed to provide data and records of a desired quality. A variety of qualitycontrol procedures, which are the operational techniques and activities used to meet the required quality objectives, have been implemented.

The numerous management and administrative procedures that control processing, record keeping, and reporting of data by USGS-EMP are not detailed in this report. Generally, data such as location, date and time of determinations, and field measurements are recorded onsite. Those data are reviewed for completeness and accuracy, stored in project files and data bases, and are subsequently included in publications by the USGS. Following publication, data are stored in a comprehensive record-keeping facility maintained by contractors for DOE.

In addition to standard USGS practices and the procedures previously described, formal unpublished technical procedures associated with the Yucca Mountain Site Characterization Project have been developed for the collection of water-level and discharge data. Those technical procedures include equipment tests and calibrations and measurement techniques to ensure that necessary and expected precision and accuracy are attained. The principal technical procedures that control the collection of data by project personnel are listed in La Camera and Westenburg (1994, p. 17).

\section{PRESENTATION OF GROUND-WATER DATA}

Tables included in this report generally list only 1999 ground-water data, whereas figures 2-13 show data for selected periods of record to illustrate changes in ground-water resources through time. Exceptions are tables 3, 4, and 10; tables 3 and 4 include data from 2000 used to determine correction factors for electrictape measurements made during 1999, and table 10 includes a summary of historical water-level measurements at monitoring sites in Jackass Flats. Below is a description of the content of the tables and figures presented in this report.
Tables 5-9 list ground-water data that have been collected and compiled in the Yucca Mountain region as part of this study. Figures 2-11 are hydrographs and other graphical representations of selected data from the tables in this and previous reports on selected ground-water data for the Yucca Mountain region. Tables 5-9 and figures 2-11 are included at the back of this report.

Pumping water from or injecting water into a well or nearby well may result in short-term variations in water levels that differ from long-term or sustained ground-water levels. Observations about such activities (noted by field personnel during site visits) and corresponding water levels, which may represent short-term conditions, are recorded under "site status" in table 5. Data which may reflect short-term conditions, however, are excluded from the figures that show variations in water level through time.

Table 5 lists periodic measurements of depth to water and water-level altitude at 35 sites (including a flowing well) for 1999. Periodical data are from manual onsite measurements of depth to water. Data collected by other agencies or programs are subject to revision upon further review by that agency or program.

Figures 2-5 show water levels listed in this report and previous reports on selected ground-water data for the Yucca Mountain region. Data for wells with primary contributing units of carbonate rock, volcanic rock, valley fill, and undifferentiated sedimentary rock are presented.

Tables 6 and 7 list daily average water levels at sites JF-3 and AD-6, respectively, for 1999. The daily average water levels are computed from continual water levels recorded by instrumentation at 15-minute intervals.

Figure 6 shows daily average water-level altitude and depth to water for sites JF-3 and AD-6. Daily averages are calculated on the basis of continually collected data listed in tables 6 and 7 of this report and in previous reports on selected ground-water data for the Yucca Mountain region. Data are presented for 1992 through 1999.

Table 8 lists periodic measurements of groundwater discharge at six sites for 1999. Discharge measured at site AM-2 represents a combination of flow directly through slotted casing near land surface and leakage from the casing's annular space. Data for site DV-1 reported with data source "NPS" represent monthly average discharge collected from instrumen- 
tation operated by the National Park Service. Discharge data collected by other agencies or programs are subject to revision upon further review by that agency or program.

Figure 7 shows measurements of ground-water discharge at sites AM-1a, AM-5a, and AM-8 through 1999, as listed in this and previous reports on selected ground-water data for the Yucca Mountain region.

Figures 8 and 9 show measurements of groundwater discharge through 1999 at sites AM-2 and DV-2, and DV-1, respectively, listed in this and previous reports on selected ground-water data for the Yucca Mountain region. Periodic USGS measurements for 1990, 1991, and 1992 that were tabulated by La Camera and Westenburg (1994, table 5) have been revised to reflect water previously unaccounted for at site DV-1.

Table 9 shows estimates of annual ground-water withdrawals from wells in the Yucca Mountain region for 1999. Estimated annual ground-water withdrawals are based solely on available data. Information on withdrawals provided by other agencies or programs are subject to revision upon further review by that agency or program. Ground-water withdrawals, in millions of gallons and in acre-feet, from water-supply wells are grouped by ground-water subbasin and totaled by hydrographic area (or part of a hydrographic area) for calendar year 1999.

Figures 10 and 11 show estimates of annual ground-water withdrawals listed in this and previous reports on selected ground-water data for the Yucca Mountain region. Shown are withdrawals for areas with available data within the Alkali Flat-Furnace Creek Ranch and Ash Meadows ground-water subbasins, respectively, through 1999. In each hydrographic area, ground water may have been withdrawn in years for which no estimates are available and thus no bars are shown. Total bar height equals the approximate sum of withdrawals from all areas within the subbasin for given year.

\section{DISCUSSION OF GROUND-WATER LEVELS AND GROUND-WATER WITHDRAWALS IN JACKASS FLATS}

Ground water is withdrawn from Jackass Flats to support several DOE activities (including site characterization); if those withdrawals affect ground-water levels, the effects may be detected in Jackass Flats before they are detected elsewhere within the Yucca Mountain region. This section discusses data on ground-water levels and ground-water withdrawals in Jackass Flats. Changes in water-level altitudes at a particular site through time (discussed in the text near the end of this section) are described in order of increasing distance away from water-supply wells J-13 and $\mathrm{J}-12$.

Figure 12 shows water-level altitudes for seven wells in Jackass Flats and estimated annual groundwater withdrawals in Jackass Flats from 1983 through 1999. Prior to 1983, available data on ground-water withdrawals in Jackass Flats generally represent only the withdrawals from well J-12 rather than total withdrawals from Jackass Flats. For greater consistency and comparability of data on water-level altitudes, water levels in wells J-13, J-12, and JF-3 that may have been affected by pumping or recent pumping of the well (water-level measurements associated with site status "P" or "R") are excluded from figure 12.

Water-level altitudes presented are based on periodic measurements or daily average water levels (when continual data recorded by instrumentation were available for more than half a year). Water level data for all sites, prior to 1985 , are based on periodic measurements made during site visits (and not daily averages). In addition, the data for sites JF-1, J-13, $\mathrm{J}-11$, and J-12 since 1985, for site JF-2 since 1994, and for site JF-3 prior to May 1992 also are based on periodic measurements made during site visits. Daily average water levels from the U.S. Geological Survey Site Characterization Program (R.P. Graves and J.M. Gemmell, U.S. Geological Survey, written communs., 1995-98) are presented in figure 12 for site JF-2 from 1985 to 1993 and for site JF-2a from 1985 to 1997.

Continual data collection at site JF-2 was discontinued in June 1994 but only periodic water levels are shown following December 1993. Continual data collection at site JF-2a was discontinued in October 1997 and only periodic water levels are shown following October 1997. Daily average water levels are also shown for site JF-3 from May 1992 to December 1999; longterm monitoring and continual data collection at this site began in May 1992.

Total ground-water withdrawals in Jackass Flats during 1999 consisted primarily of combined pumpage from water-supply wells $\mathrm{J}-13$ and $\mathrm{J}-12$ and test well UE-25c \#3 (about 2.5 mi northwest of well J-13), all of which penetrate volcanic rock. About 27.3, 5.7, and $0.3 \mathrm{Mgal}$, respectively, were withdrawn from 
these wells during 1999. Total ground-water withdrawals in Jackass Flats, from 1983 to 1999, are from data presented in this and previous reports on selected ground-water data for the Yucca Mountain region.

Total ground-water withdrawals from Jackass Flats during 1999 were about 33.3 Mgal. This amount is about 32 percent less than withdrawals during 1998 (48.8 Mgal) and about 36 percent less than the median withdrawal for 1983 to 1991 (52 Mgal) (La Camera and Westenburg, 1994, p. 30). Ground-water withdrawals in Jackass Flats increased from 38.9 Mgal in 1992 to $127.4 \mathrm{Mgal}$ in 1996, and then decreased to 33.3 Mgal in 1999.

Table 10 contains selected statistics derived from data shown in figure 12 for water-level altitudes in Jackass Flats. Data for wells JF-1, JF-2, JF-2a, J-13, $\mathrm{J}-11, \mathrm{~J}-12$, and JF-3 are summarized for the selected baseline periods and for subsequent calendar years through 1999. The table shows the number of measurements; minimum, maximum, and median waterlevel altitude; and the average deviation of measured water-levels from the median water level for each period.

To minimize effects of variability in measurement frequency on median water-level altitudes calculated for the period prior to 1992, the selection of a baseline period for each site was based on (1) the maximum number of consecutive years for which waterlevel measurements are available and (2) consecutive years containing similar frequencies of water-level measurements. For consistency, the baseline period selected at instrumented wells JF-2 and JF-2a was the period following installation of continual recorders. The baseline period for JF-3 was based solely on the availability of daily average water levels from the continual data recorder, which was installed in May 1992. These baseline periods are the standard to which following years are compared.

The median water-level altitudes shown in table 10 indicate a statistically representative ground-water level for a particular time. Median water-level measurements are listed because the calculated median is less affected by a few high or low values than the arithmetic mean. When more than half a year of continual data at a site were available (recorded hourly or more frequently by instrumentation), the median daily average water level is listed.

The average deviation indicates the dispersion of individual measurements about the median; it provides an indication of how precisely the median approxi- mates a typical water-level altitude during the period. The average deviation equals the sum of the absolute differences between individual measurements and the median, divided by the number of individual measurements.

Figure 13 shows the median water-level altitudes and the average deviation of the water levels for wells JF-1, JF-2, JF-2a, J-13, J-11, J-12, and JF-3 for baseline periods and for subsequent years through 1999. Median annual ground-water withdrawal in Jackass Flats for 1983-91 and estimated annual withdrawals for subsequent years through 1999 are also included in figure 13. Selected information presented in the figure is summarized in the following discussion.

Median water-level altitude in water-supply well J-13 is 2,390.0 ft above sea level for the baseline period and for 1999. Median water-level altitude in well J-13 increased $0.2 \mathrm{ft}$ from 1998 to 1999 . Groundwater withdrawals from well J-13 declined from 42.5 Mgal in 1998 to $27.3 \mathrm{Mgal}$ in 1999.

Median water-level altitude in water-supply well $\mathrm{J}-12$, which is $3.0 \mathrm{mi}$ south of $\mathrm{J}-13$, is $2,388.3 \mathrm{ft}$ for the baseline period and for 1999. Median water-level altitude in well J-12 increased $0.3 \mathrm{ft}$ from 1998 to 1999. Ground-water withdrawals from well J-12 increased from 5.1 Mgal in 1998 to $5.7 \mathrm{Mgal}$ in 1999.

Median water-level altitude in well JF-3, which is $0.5 \mathrm{mi}$ south of water-supply well $\mathrm{J}-12$, is $2,388.3 \mathrm{ft}$ for the baseline period. Median water-level altitude for 1999 in well JF-3 was 2,388.2 ft, which is $0.1 \mathrm{ft}$ lower than the median for the baseline period but $0.2 \mathrm{ft}$ higher than the median for 1998. The change in median water-level altitude between the baseline period and 1999 is equal to the average deviation of the median for the baseline period (as indicated by the average deviation for 1992-93).

At wells J-13, J-12, and JF-3 (which penetrate volcanic rock and also are at or near principal points of ground-water withdrawals from volcanic rock) the 1999 median water-level altitudes are either equal to their baseline medians or are within the historical variability of their medians (represented by the average deviation of their respective baseline periods). The 1999 median water-level altitude in each well is 0.2-0.3 ft higher than their 1998 median altitudes.

Median water-level altitude in well JF-2, which penetrates volcanic rock about 1.4 mi north of watersupply well J-13, is $2,392.1 \mathrm{ft}$ for the baseline period. Median water-level altitude in well JF-2 for 1999 was 
$2,392.5 \mathrm{ft}$, which is $0.4 \mathrm{ft}$ higher than the median for the baseline period and the median for 1998. The average deviation of water levels during the baseline period from 1985 to $1991(0.3 \mathrm{ft})$ is less than the changes in the median water levels.

Median water-level altitude in well JF-2a, which penetrates carbonate rock about 2.0 mi northwest of supply well J-13, is $2,468.6 \mathrm{ft}$ for the baseline period. The median water-level altitude for 1999 was $2,470.2 \mathrm{ft}$, which is $1.6 \mathrm{ft}$ higher than the median for the baseline period and $0.2 \mathrm{ft}$ higher than the median for 1998. The increase in water level between the baseline period and 1999 is greater than the average deviation of the median water-level altitude for the baseline period from 1985 to $1991(0.4 \mathrm{ft})$. Median water levels in well JF-2a have risen $0.1-0.3 \mathrm{ft}$ per year since 1992.

Median water-level altitude in well JF-1, which penetrates volcanic rock about 3.2 mi north of the water-supply well J-13, is 2,392.5 ft for the baseline period. Median water-level altitude in well JF-1 for 1999 is $2,392.7 \mathrm{ft}$, which is $0.2 \mathrm{ft}$ higher than the median for 1998 and the median for the baseline period. The average deviation of the median for the baseline period from 1985 to $1991(0.2 \mathrm{ft})$, is equal to the change in the median between the baseline period and 1999.

Median water-level altitude in well J-11, which penetrates volcanic rock about 6.3 mi east of watersupply well J-13, is $2,402.2 \mathrm{ft}$ for the baseline period. Median water-level altitude in well J-11 for 1999 was $2,402.4 \mathrm{ft}$, which is $0.2 \mathrm{ft}$ higher than the baseline median and $0.2 \mathrm{ft}$ lower than the median for 1998 . The average deviation of the median for the baseline period from 1990 to 1991 ( $0.1 \mathrm{ft})$, is less than the change in the median between the baseline period and 1999.

In summary, the 1999 estimated ground-water withdrawal in Jackass Flats was about 33.3 Mgal. Withdrawals averaged about $52 \mathrm{Mgal}$ from 1983 to 1991 and about 48.8 Mgal in 1998. The 1999 median water-level altitudes were determined for seven wells. For each well the 1999 median water-level altitude was compared to its baseline and 1998 median waterlevel altitude. The 1999 median water-level altitudes for six of the seven wells were either equal to or $(0.2-1.6 \mathrm{ft})$ greater than their respective baseline medians. The median water-level altitude of well JF-3 was $0.1 \mathrm{ft}$ less than its 1992-93 baseline median. From 1998 to 1999, the median water-level altitudes in six of the wells increased from 0.2 to $0.4 \mathrm{ft}$, but the median water-level altitude in well J-11 declined $0.2 \mathrm{ft}$.

\section{REFERENCES CITED}

Boucher, M.S., 1994, Water levels in wells J-11 and J-12, 1989-91, Yucca Mountain area, Nevada: U.S. Geological Survey Open-File Report 94-303, 9 p.

Buchanan, T.J., and Somers, W.P., 1969, Discharge measurements at gaging stations: U.S. Geological Survey Techniques of Water-Resources Investigations, book 3, chap. A8, 65 p.

Cardinalli, J.L., Roach, L.M., Rush, F.E., and Vasey, B.J., 1968, State of Nevada hydrographic areas: Nevada Division of Water Resources map, scale 1:500,000.

Dudley, W.W., Jr., and Larson, J.D., 1976, Effect of irrigation pumping on desert pupfish habitats in Ash Meadows, Nye County, Nevada: U.S. Geological Survey Professional Paper 927, 52 p.

Fenneman, N.M., 1931, Physiography of western United States: New York, McGraw-Hill, 534 p.

Gemmell, J.M., 1990, Water levels in periodically measured wells in the Yucca Mountain area, Nevada, 1988: U.S. Geological Survey Open-File Report 90-113, 47 p.

Graves, R.P., 2000, Water levels in the Yucca Mountain area, Nevada, 1997-98: U.S. Geological Survey OpenFile Report 00-186, 81 p.

Graves, R.P., and Goemaat, R. L., 1998, Water levels in the Yucca Mountain area, Nevada, 1995: U.S. Geological Survey Open-File Report 97-101, 92 p.

Graves, R.P., Tucci, Patrick, and Goemaat, R.L., 1996, Water levels in the Yucca Mountain area, Nevada, 1994: U.S. Geological Survey Open-File Report 95-757, $101 \mathrm{p}$.

Hale, G.S., and Westenburg, C.L., 1995, Selected groundwater data for Yucca Mountain region, southern Nevada and eastern California, calendar year 1993: U.S. Geological Survey Open-File Report 95-158, $67 \mathrm{p}$.

Harrill, J.R., Gates, J.S., and Thomas, J.M., 1988, Major ground-water flow systems in the Great Basin region of Nevada, Utah, and adjacent states: U.S. Geological Survey Hydrologic Investigations Atlas HA-694-C, 2 sheets.

Johnston, R.H., 1968, U.S. Geological Survey tracer study, Amargosa Desert, Nye County, Nevada, Part 1, Exploratory drilling, tracer well construction and testing, and preliminary findings: U.S. Geological Survey Report USGS-474-98, 64 p. [Available only from National Technical Information Service, U.S. Department of Commerce, Springfield, VA 22161.] 
Kilpatrick, F.A., and Schneider, V.R., 1983, Use of flumes in measuring discharge: U.S. Geological Survey Techniques of Water-Resources Investigations, book 3, chap. A14, 46 p.

Kilroy, K.C., 1991, Ground-water conditions in Amargosa Desert, Nevada-California, 1952-87: U.S. Geological Survey Water-Resources Investigations Report 89-4101, 93 p.

La Camera, R.J., and Locke, G.L., 1998, Selected groundwater data for Yucca Mountain region, southern Nevada and eastern California, through December 1996: U.S. Geological Survey Open-File Report $97-$ $821,75 \mathrm{p}$

La Camera, R.J., Locke, G.L., and Munson, R.H., 1999, Selected ground-water data for Yucca Mountain region, southern Nevada and eastern California, through December 1997: U.S. Geological Survey Open-File Report 98-628, 84 p.

La Camera, R.J., and Westenburg, C.L., 1994, Selected ground-water data for Yucca Mountain region, southern Nevada and eastern California, through December 1992: U.S. Geological Survey Open-File Report 94-54, $161 \mathrm{p}$.

La Camera, R.J., Westenburg, C.L., and Locke, G.L., 1996, Selected ground-water data for Yucca Mountain region, southern Nevada and eastern California, through December 1995: U.S. Geological Survey Open-File Report 96-553, 75 p.

Laczniak, R.J., Cole, J.C., Sawyer, D.A., and Trudeau, D.A., 1996, Summary of hydrogeologic controls on groundwater flow at the Nevada Test Site, Nye County, Nevada: U.S. Geological Survey Water-Resources Investigations Report 96-4109, 59 p.

Lobmeyer, D.H., Luckey, R.R., O'Brien, G.M., and Burkhardt, D.J., 1995, Water levels in continuously monitored wells in the Yucca Mountain area, Nevada, 1989: U.S. Geological Survey Open-File Report 93-98, $173 \mathrm{p}$.

Locke, G.L., 2001, Selected ground-water data for Yucca Mountain region, southern Nevada and eastern California, through December 1998: U.S. Geological Survey Open-File Report 99-250, 78 p.

Luckey, R.R., Lobmeyer, D.H., and Burkhardt, D.J., 1993, Water levels in continuously monitored wells in the Yucca Mountain area, Nevada, 1985-88: U.S. Geological Survey Open-File Report 91-493, 252 p.

McKinley, P.W., Long, M.P., and Benson, L.V., 1991, Chemical analysis of water from selected wells and springs in the Yucca Mountain area, Nevada and southeastern California: U.S. Geological Survey Open-File Report 90-355, 47 p.

O'Brien, G.M., 1991, Water levels in periodically measured wells in the Yucca Mountain area, Nevada, 1989: U.S. Geological Survey Open-File Report 91-178, 51 p.
1993, Earthquake-induced water-level fluctuations at Yucca Mountain, Nevada, June 1992: U.S. Geological Survey Open-File Report 93-73, 12 p.

O’Brien, G.M., Tucci, Patrick, and Burkhardt, D.J., 1995, Water levels in the Yucca Mountain area, Nevada, 1992: U.S. Geological Survey Open-File Report 94-311, 74 p.

Robison, J.H., 1984, Ground-water level data and preliminary potentiometric-surface maps, Yucca Mountain and vicinity, Nye County, Nevada: U.S. Geological Survey Water-Resources Investigations Report 84-4197, 8 p.

Robison, J.H., Stephens, D.M., Luckey, R.R., and Baldwin, D.A., 1988, Water levels in periodically measured wells in the Yucca Mountain area, Nevada, 1981-87: U.S. Geological Survey Open-File Report 88-468, $132 \mathrm{p}$.

Rush, F.E., 1968, Index of hydrographic areas in Nevada: Nevada Division of Water Resources, Information Report 6, 38 p.

Thordarson, William, Young, R.A., and Winograd, I.J., 1967, Records of wells and test holes in the Nevada Test Site and vicinity (through December 1966): U.S. Geological Survey Open-File Report TEI-872, 26 p.

Tucci, Patrick, and Burkhardt, D.J., 1995, Potentiometricsurface map, 1993, Yucca Mountain and vicinity, Nevada: U.S. Geological Survey Water-Resources Investigations Report 95-4149, 15 p.

Tucci, Patrick, Goemaat, R.L., and Burkhardt, D.J., 1996, Water levels in the Yucca Mountain area, Nevada, 1993: U.S. Geological Survey Open-File Report 95-159, 94 p.

Tucci, Patrick, O’Brien, G.M., and Burkhardt, D.J., 1996, Water levels in the Yucca Mountain area, Nevada, 1990-91: U.S. Geological Survey Open-File Report 94-111, 107 p.

U.S. Geological Survey, 1996, Availability of ground-water data for California, water year 1995: U.S. Geological Survey Fact Sheet FS-114-96, 2 p.

Waddell, R.K., Robison, J.H., and Blankennagel, R.K., 1984, Hydrology of Yucca Mountain and vicinity, Nevada-California-Investigative results through mid1983: U.S. Geological Survey Water-Resources Investigations Report 84-4267, 72 p.

Westenburg, C.L., and La Camera, R.J., 1996, Selected ground-water data for Yucca Mountain region, southern Nevada and eastern California, through December 1994: U.S. Geological Survey Open-File Report 96-205, $73 \mathrm{p}$.

Winograd, I.J., and Thordarson, William, 1975, Hydrogeologic and hydrochemical framework, south-central Great Basin, Nevada-California, with special reference to the Nevada Test Site: U.S. Geological Survey Professional Paper 712-C, 126 p. 


\section{BASIC DATA}




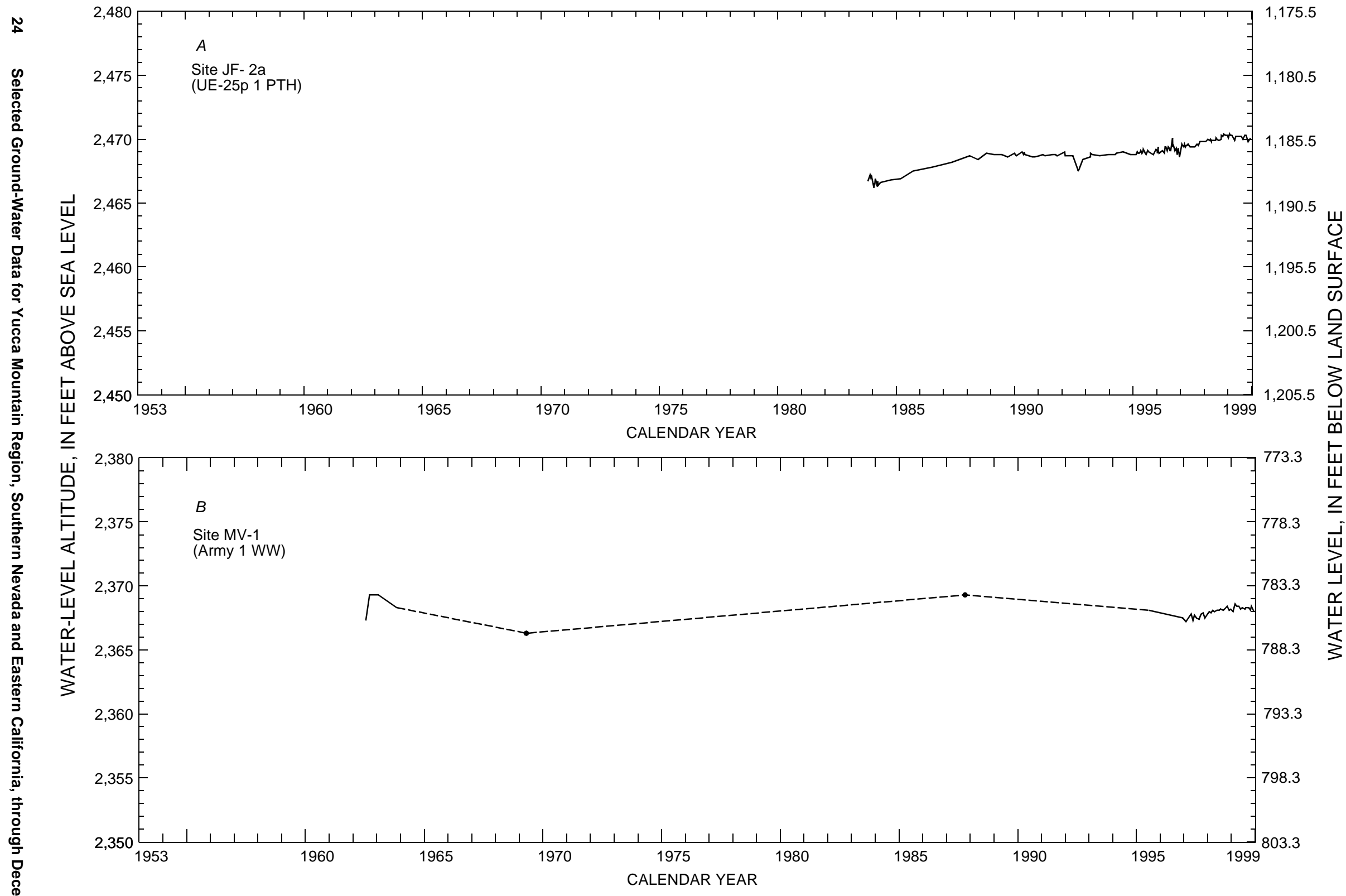

Figure 2. Periodic water levels through 1999 for selected sites at which primary contributing units are carbonate rock. Lines connect periodic data presented in this and previous reports on selected ground-water data for Yucca Mountain region. Solid lines connect yearly or more frequent measurements. Lines are dashed where measurements were not available for consecutive calendar years. A solid dot is a single isolated measurement. Data that may represent short-term conditions at a site have been excluded (see section "Presentation of Ground-Water Data"). 


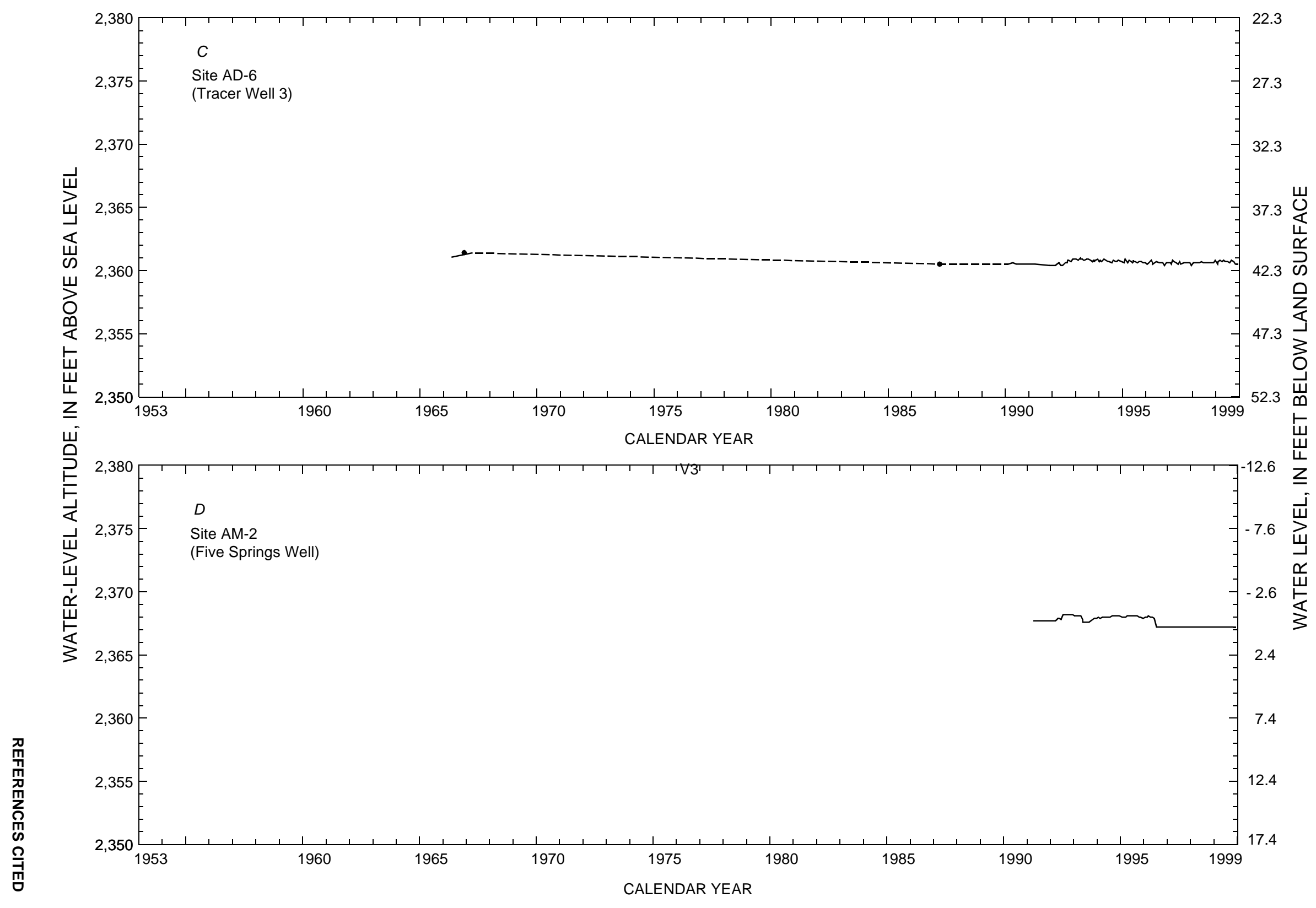

Figure 2. Continued. 


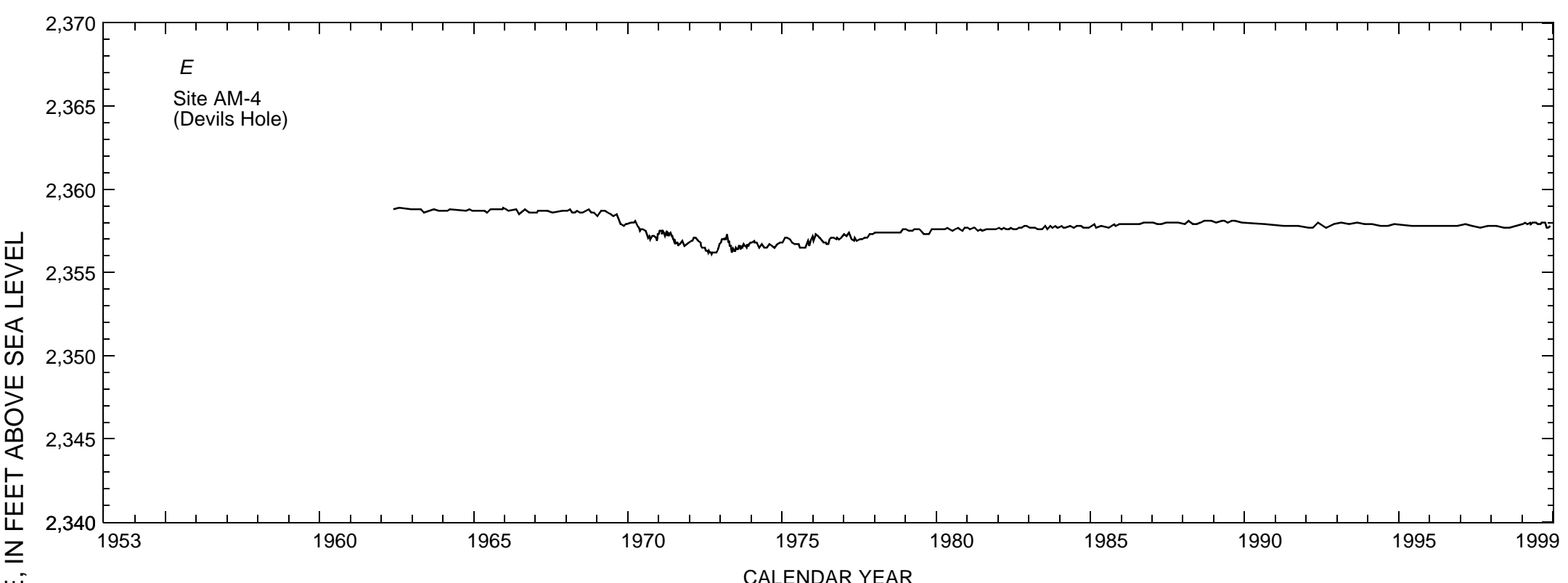

$-10.1$
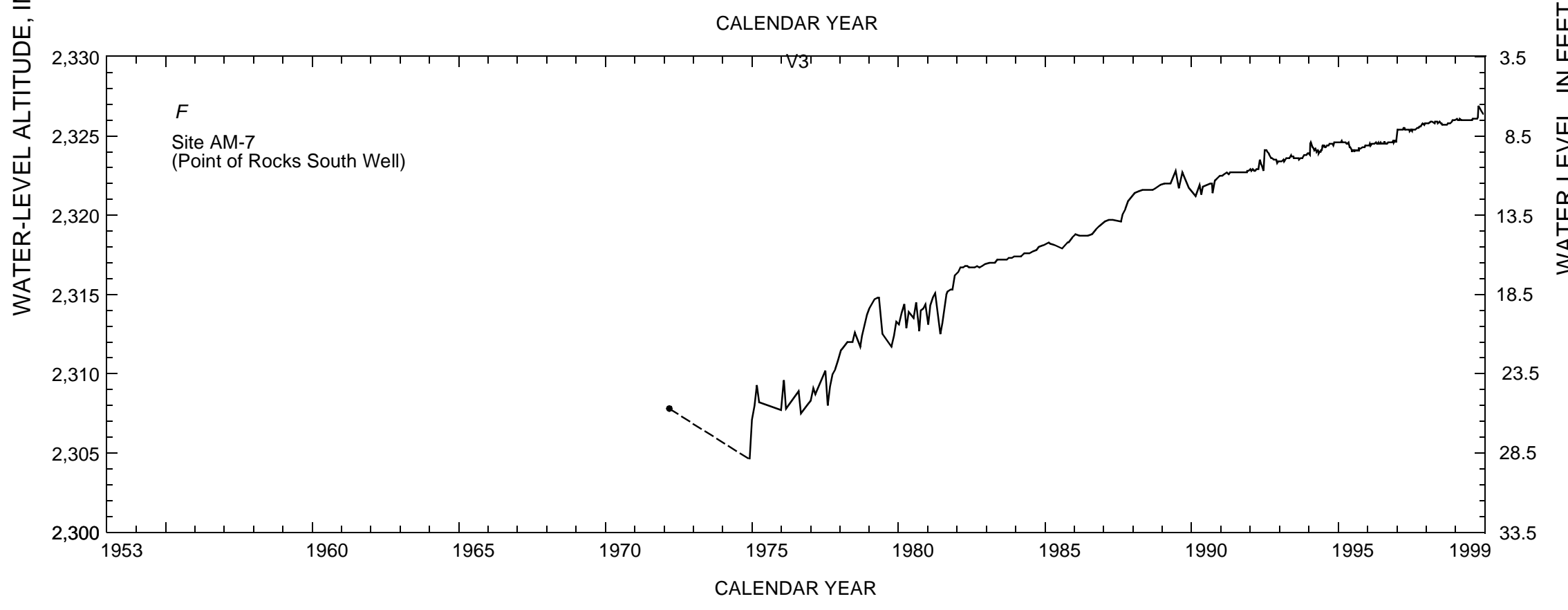

Figure 2. Continued. 


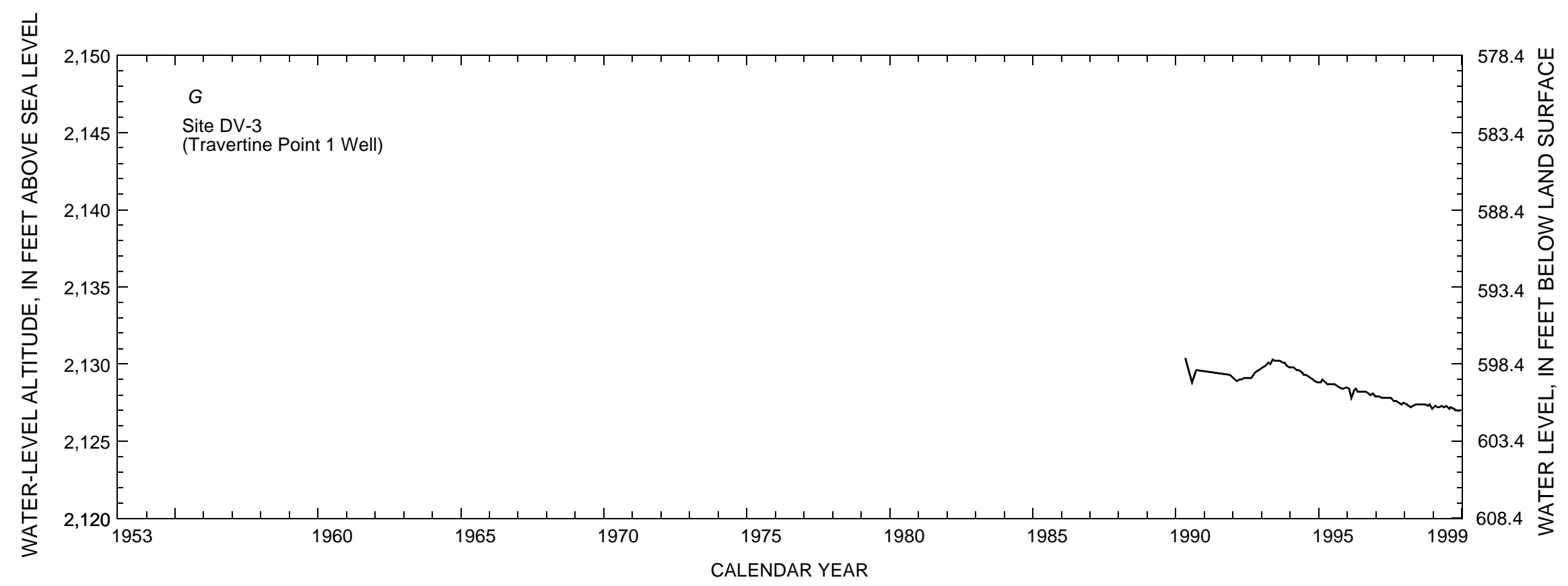

Figure 2. Continued.

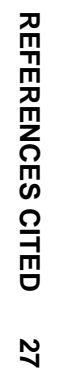




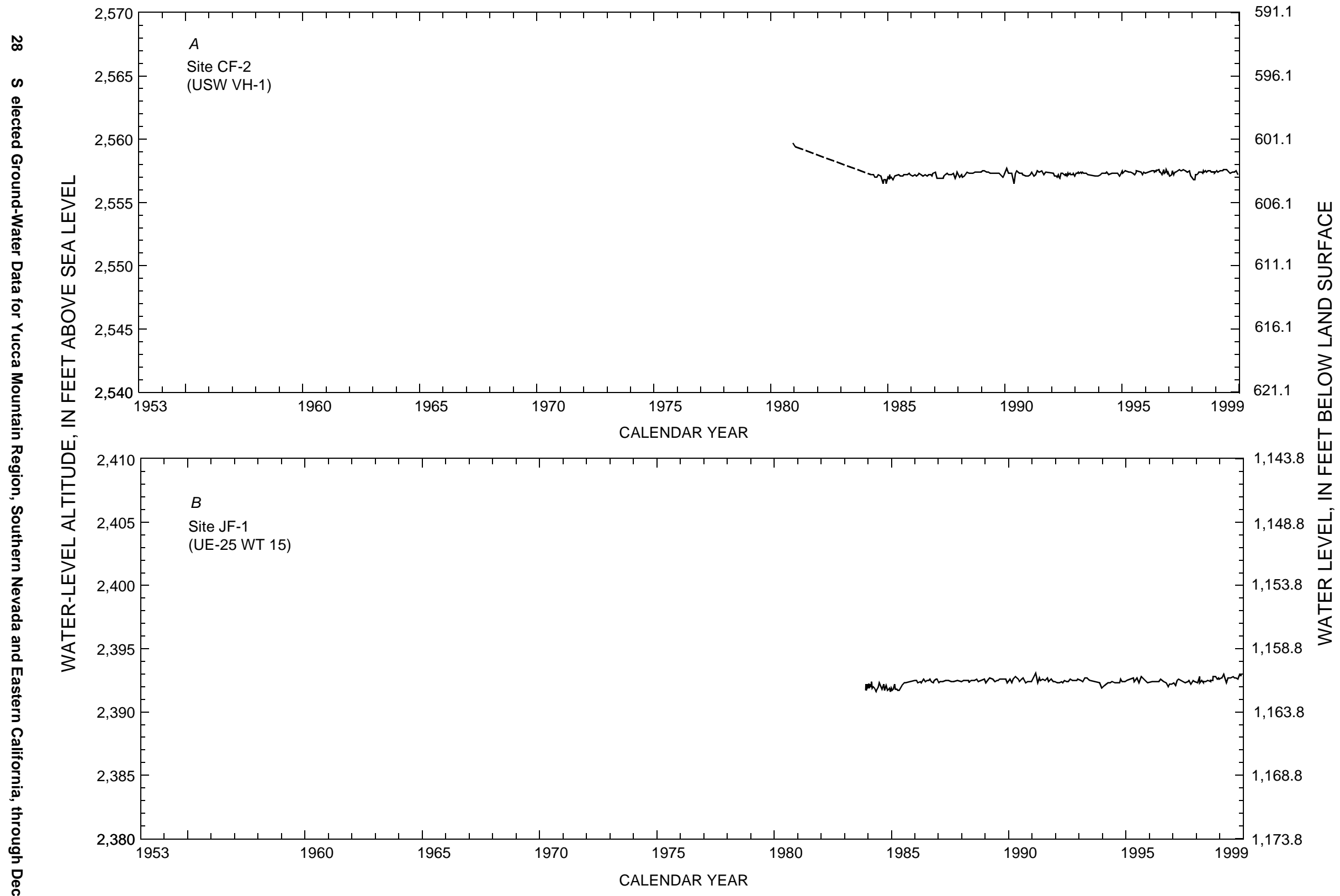

Figure 3. Periodic water levels through 1999 for selected sites at which primary contributing units are volcanic rock. Lines connect periodic data presented in this and previous reports on selected ground-water data for Yucca Mountain region. Solid lines connect yearly or more frequent measurements. Lines are dashed where measurements were not available for consecutive calendar years. A solid dot is a single isolated measurement. Data that may represent short-term conditions at a site have been excluded (see section "Presentation of Ground-Water Data"). 


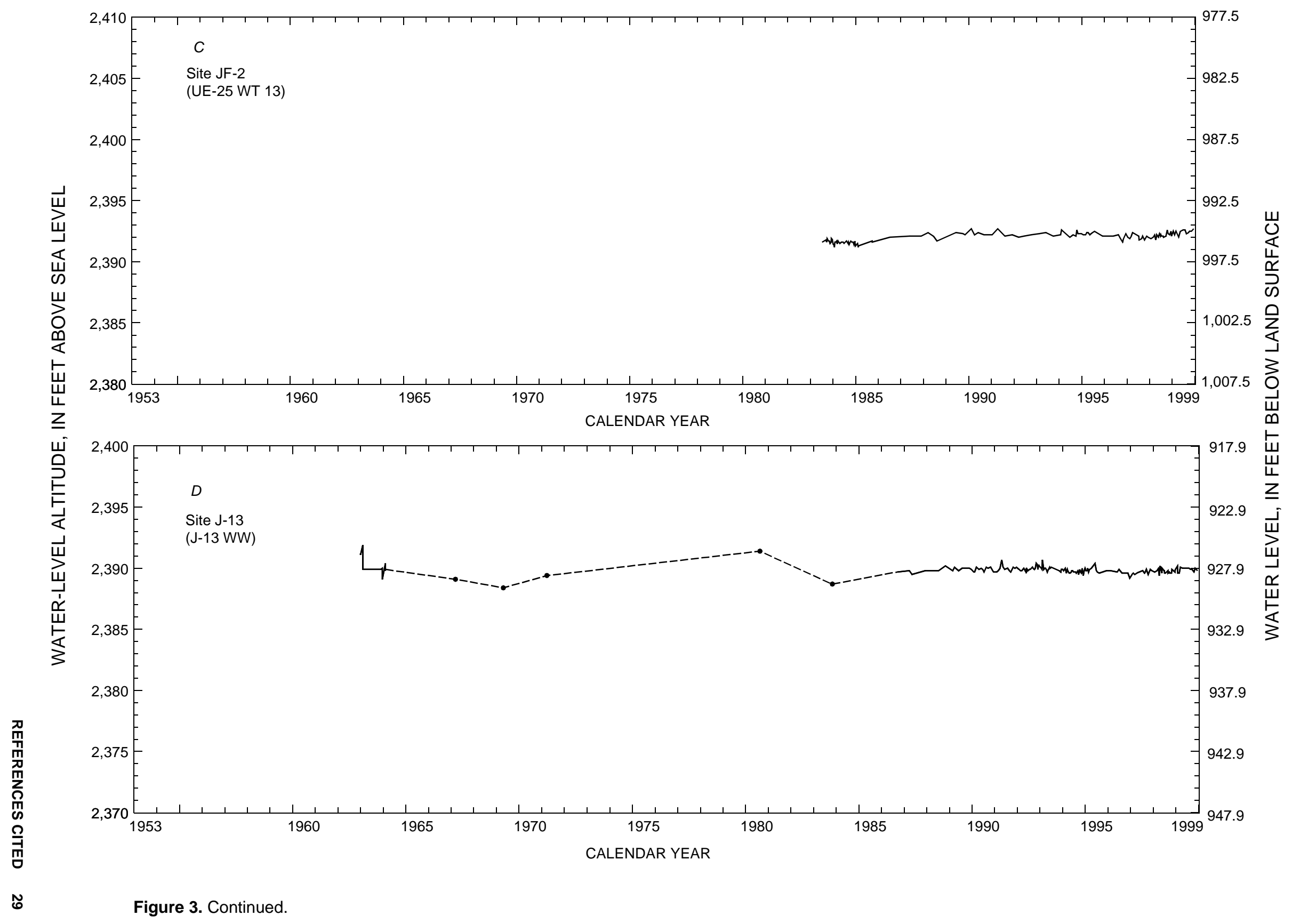



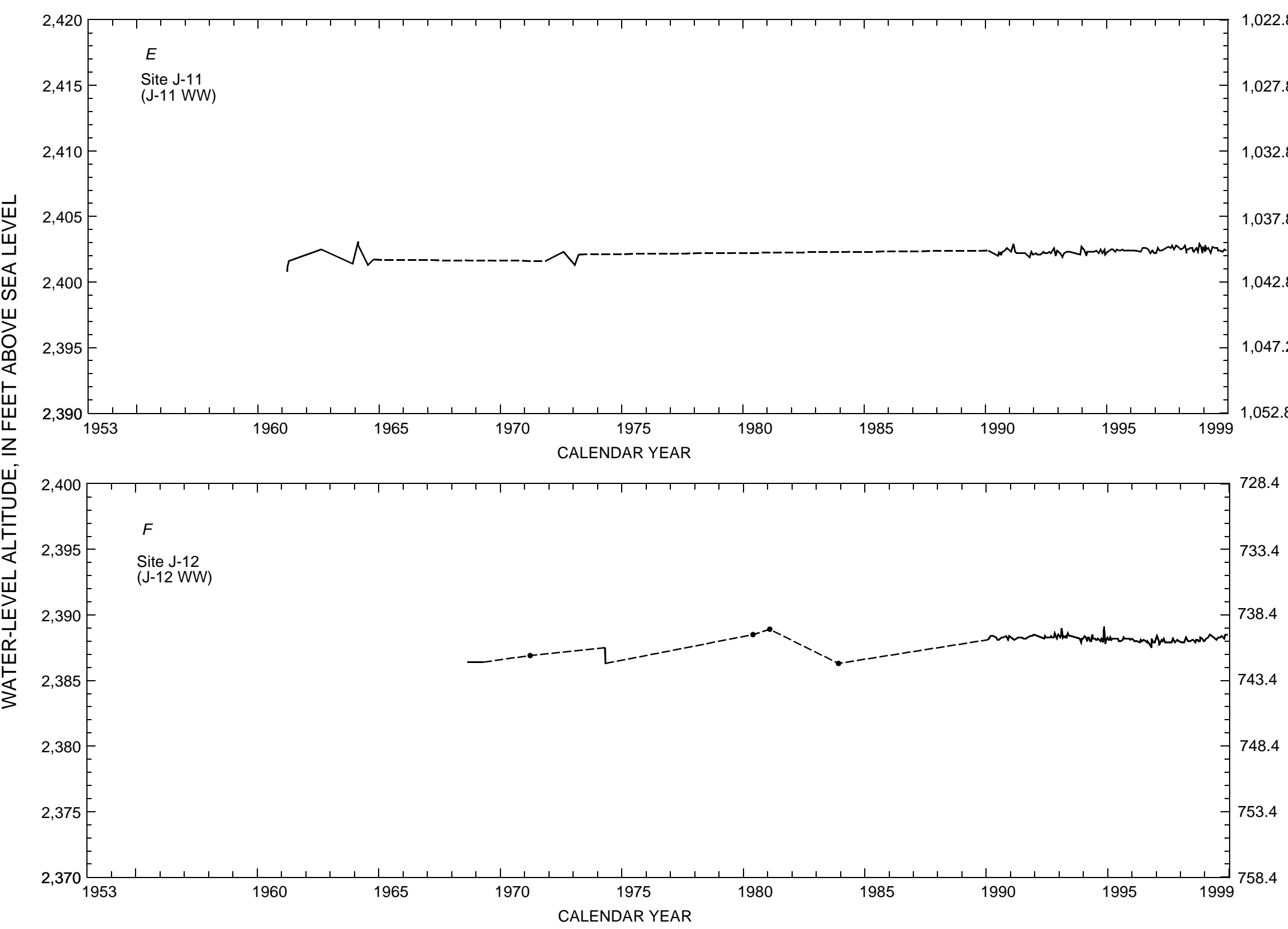

Figure 3. Continued. 


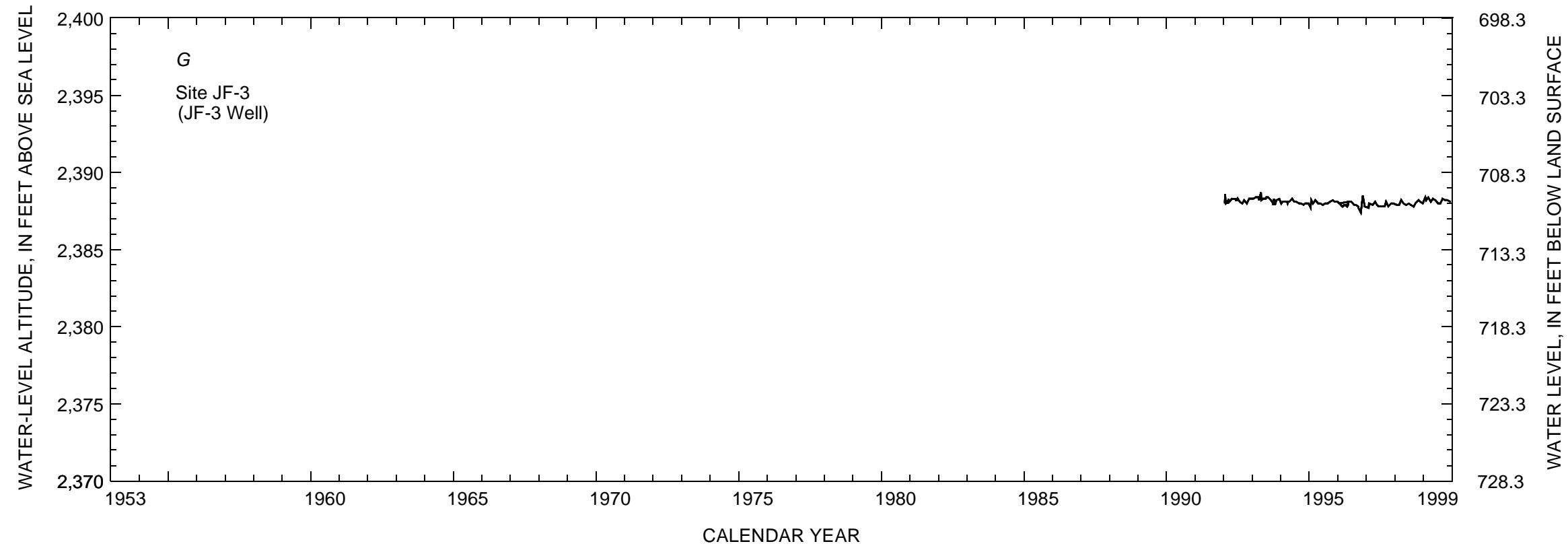

Figure 3. Continued.

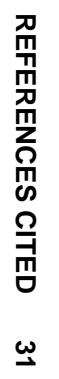




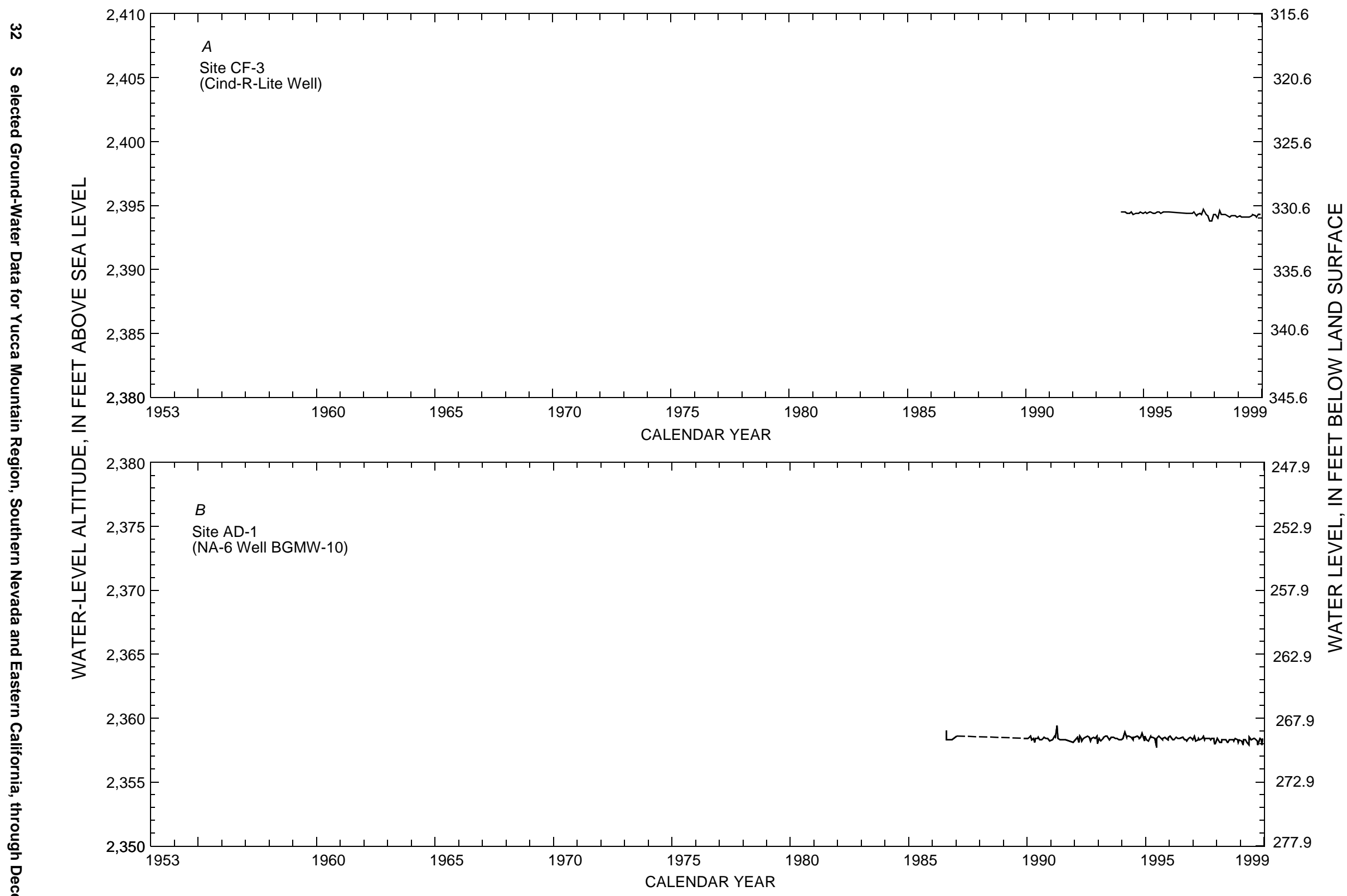

Figure 4. Periodic water levels through 1999 for selected sites at which primary contributing units are valley fill. Lines connect periodic data presented in this and previous reports on selected ground-water data for Yucca Mountain region. Solid lines connect yearly or more frequent measurements. Lines are dashed where measurements were not available for consecutive calendar years. A solid dot is a single isolated measurement. Data that may represent short-term conditions at a site have been excluded (see section "Presentation of Ground-Water Data"). 


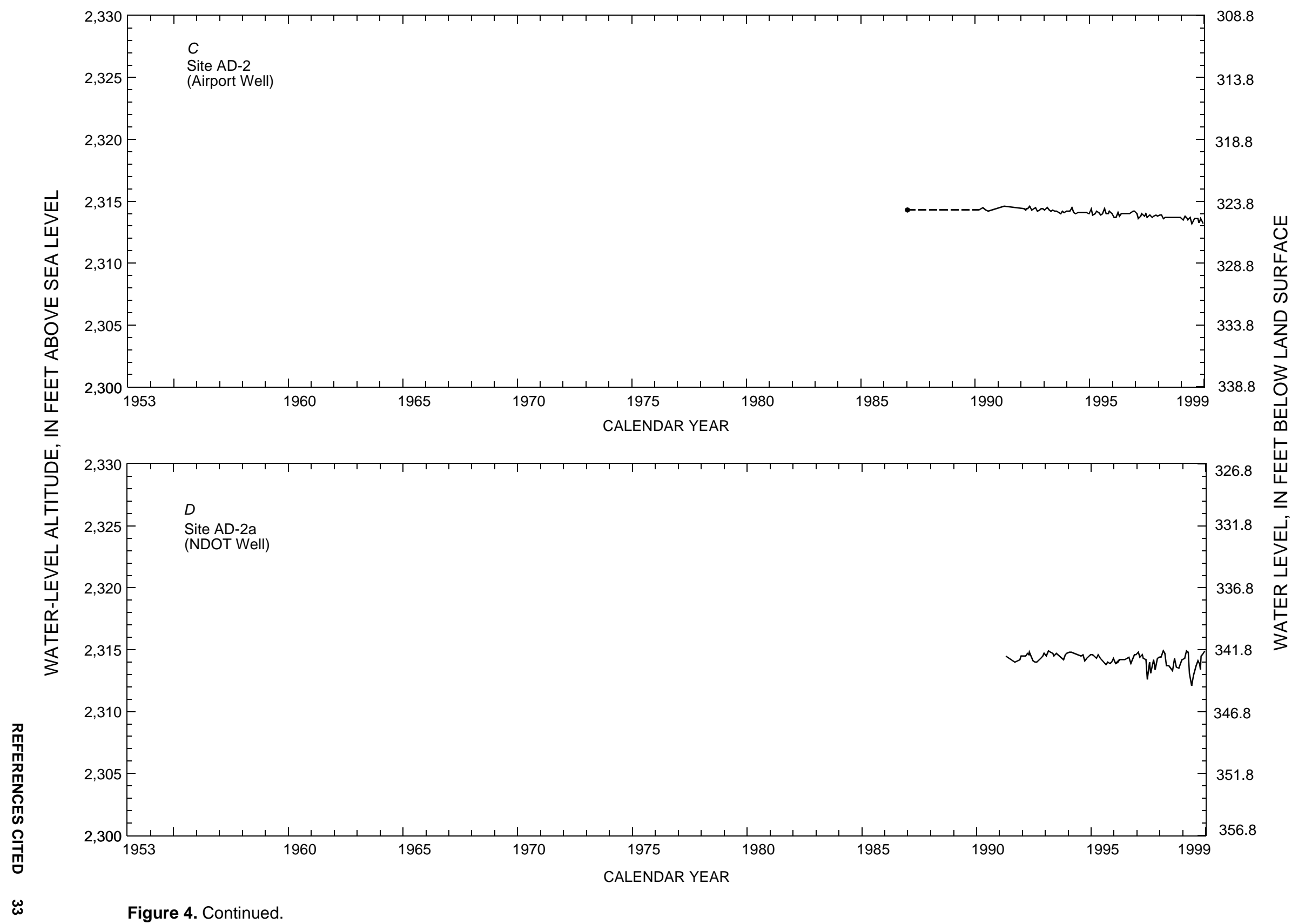




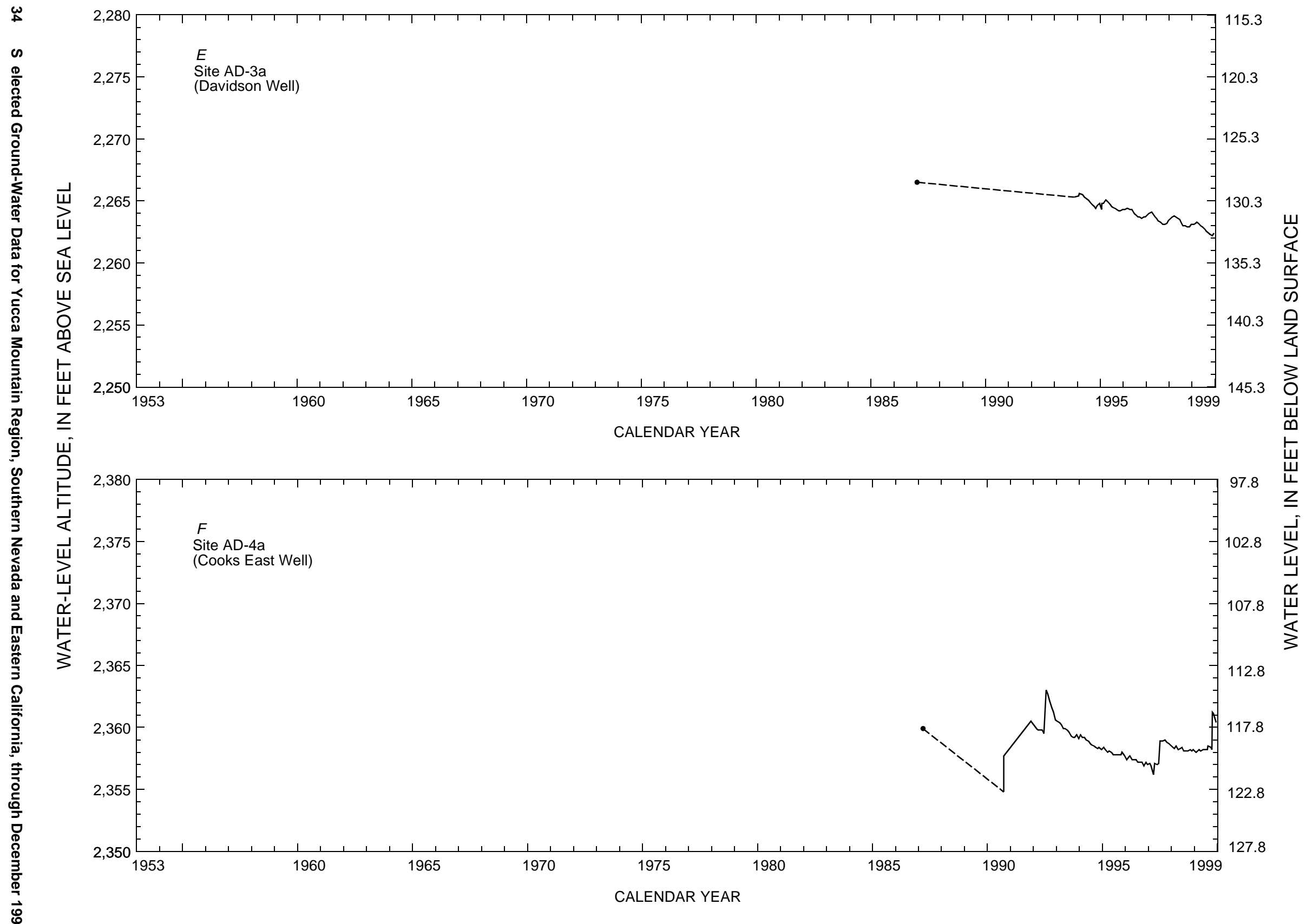

Figure 4. Continued. 


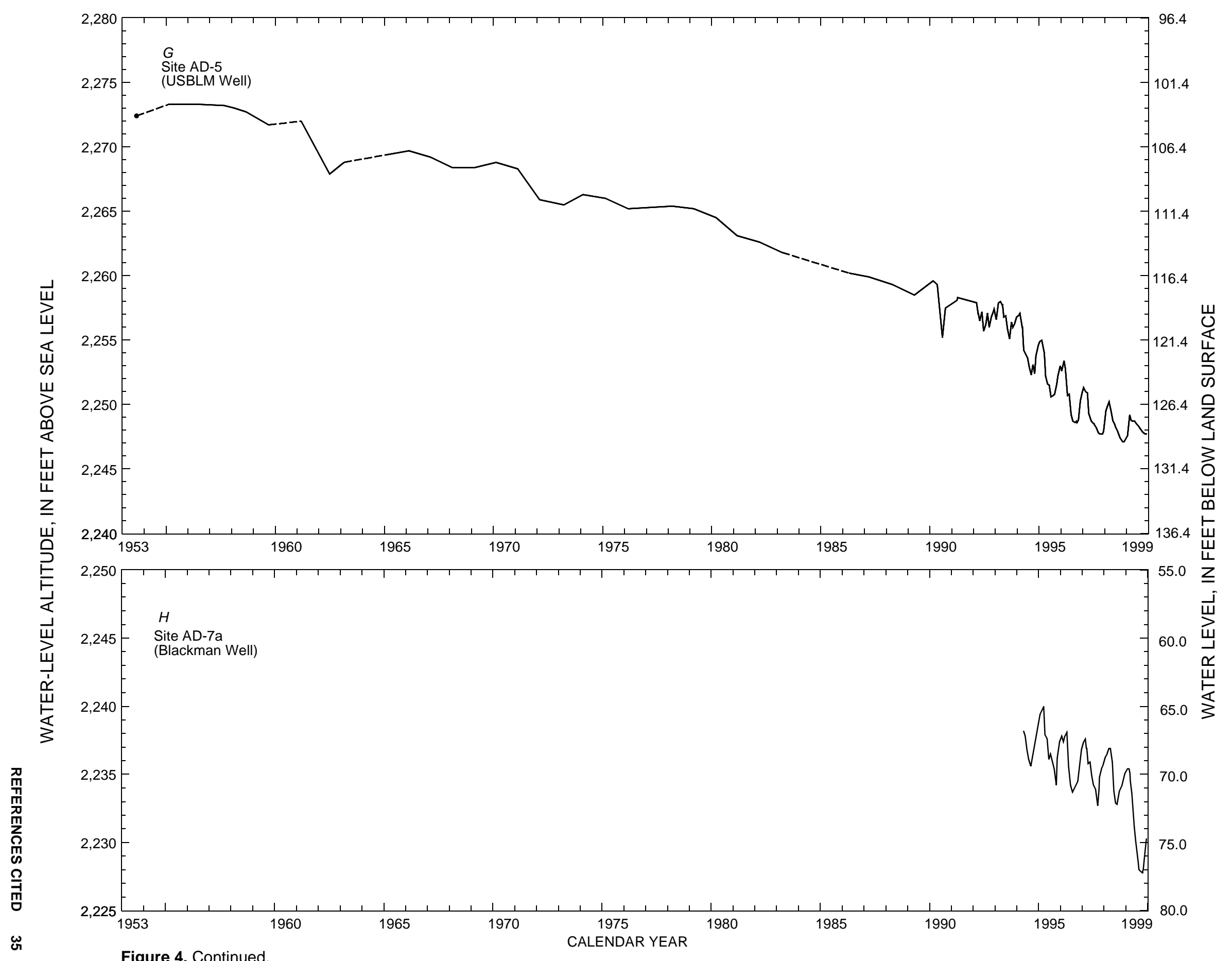

Figure 4. Continued. 


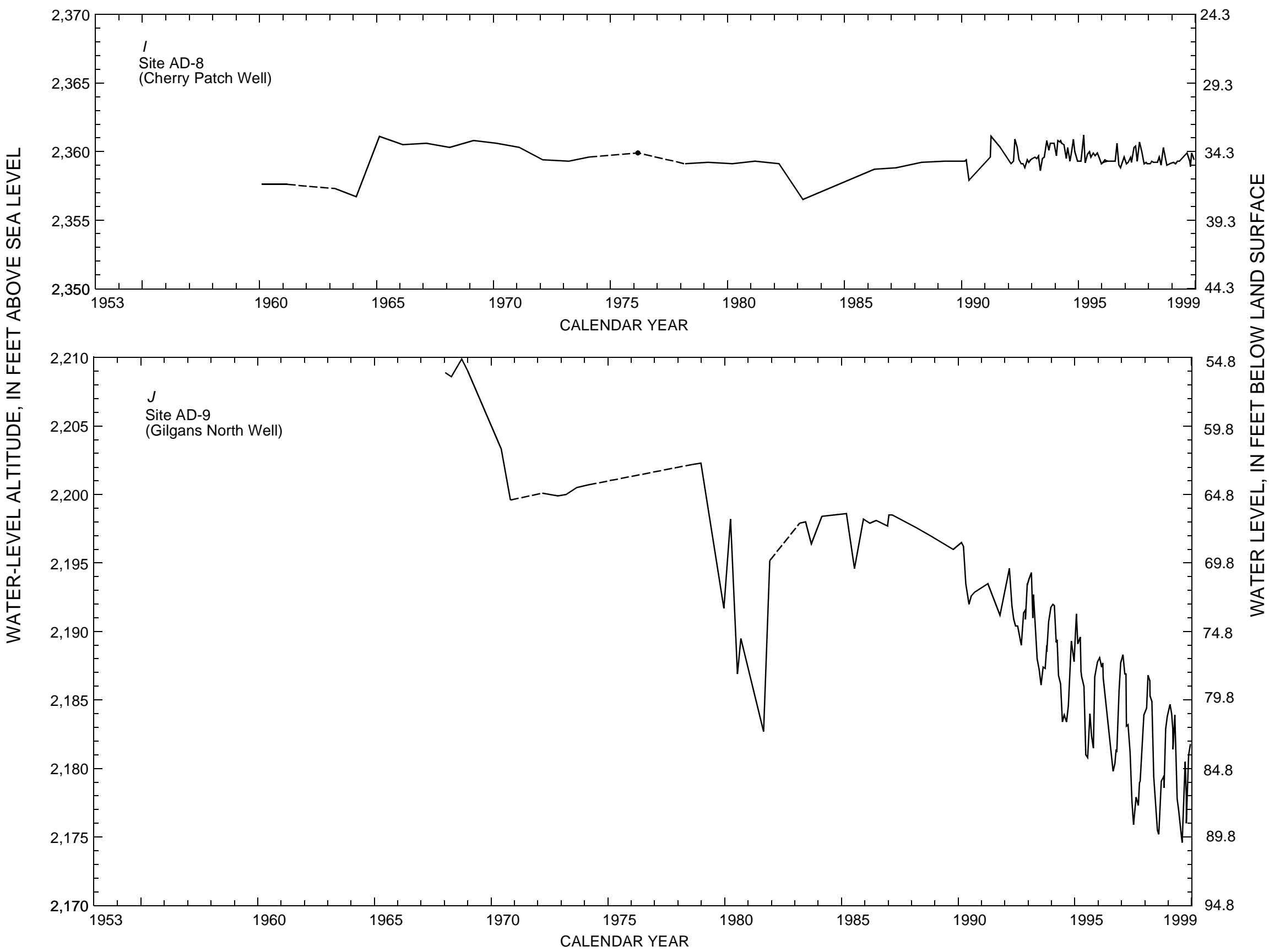

Figure 4. Continued. 


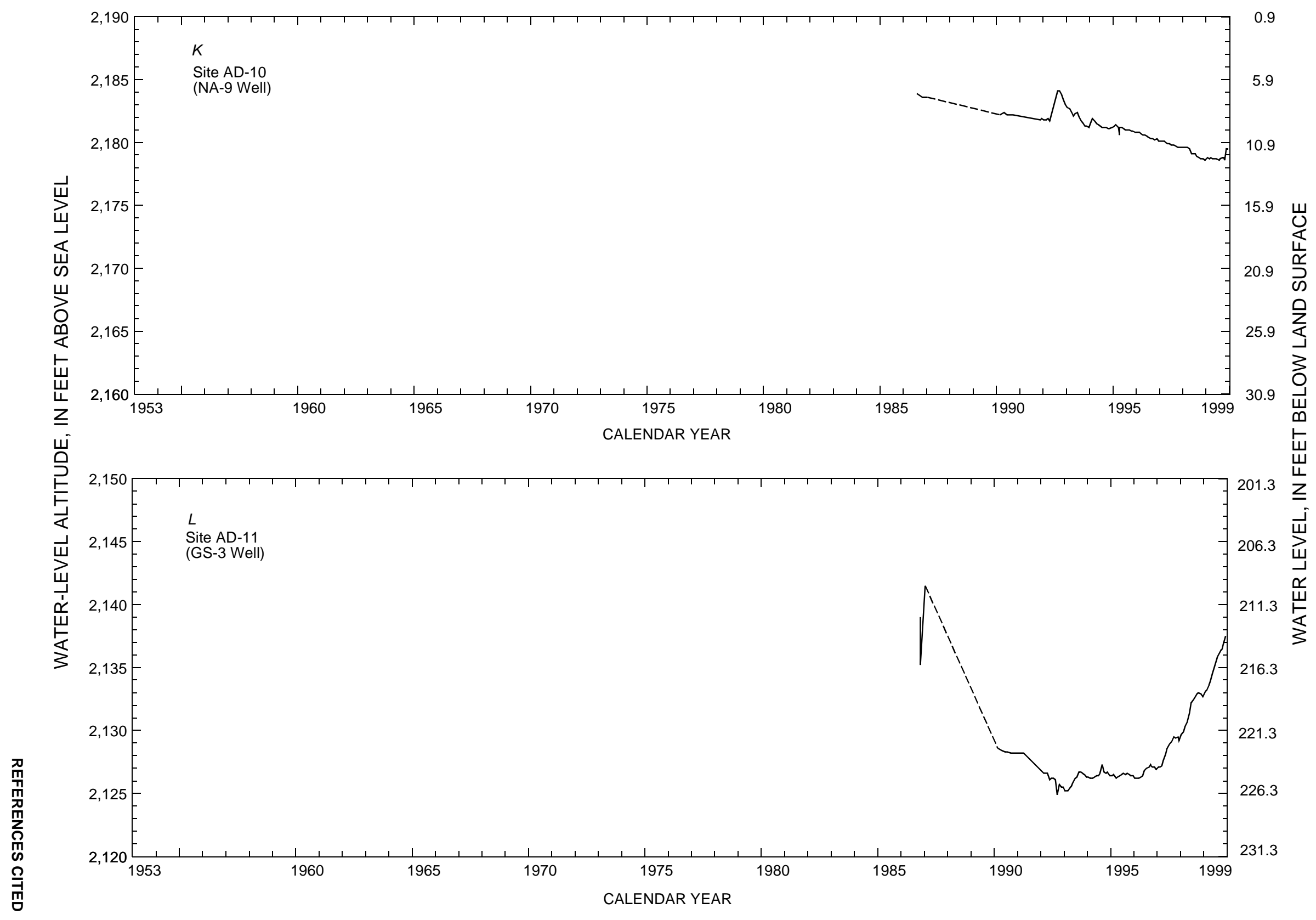

ข

Figure 4. Continued. 


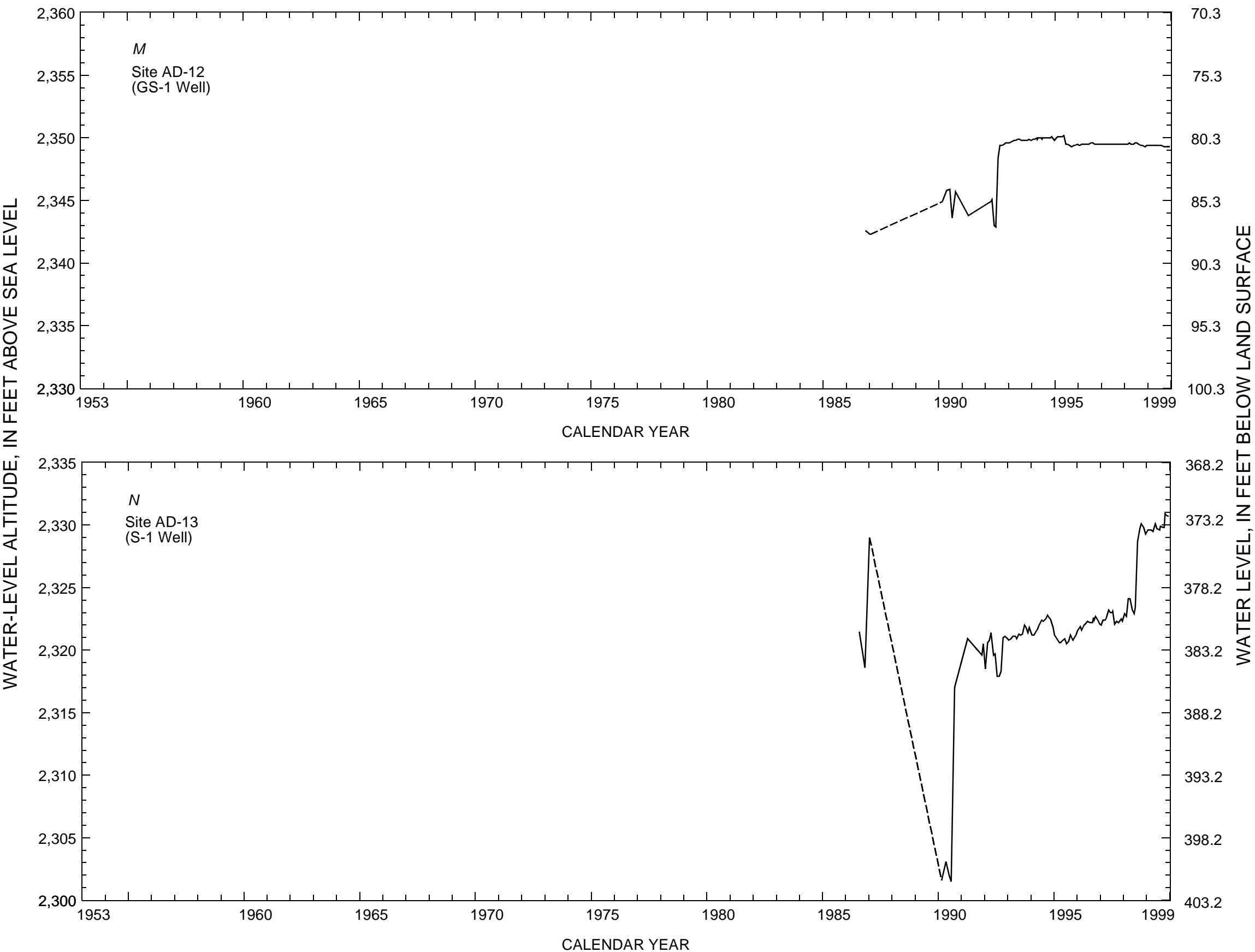

Figure 4. Continued. 


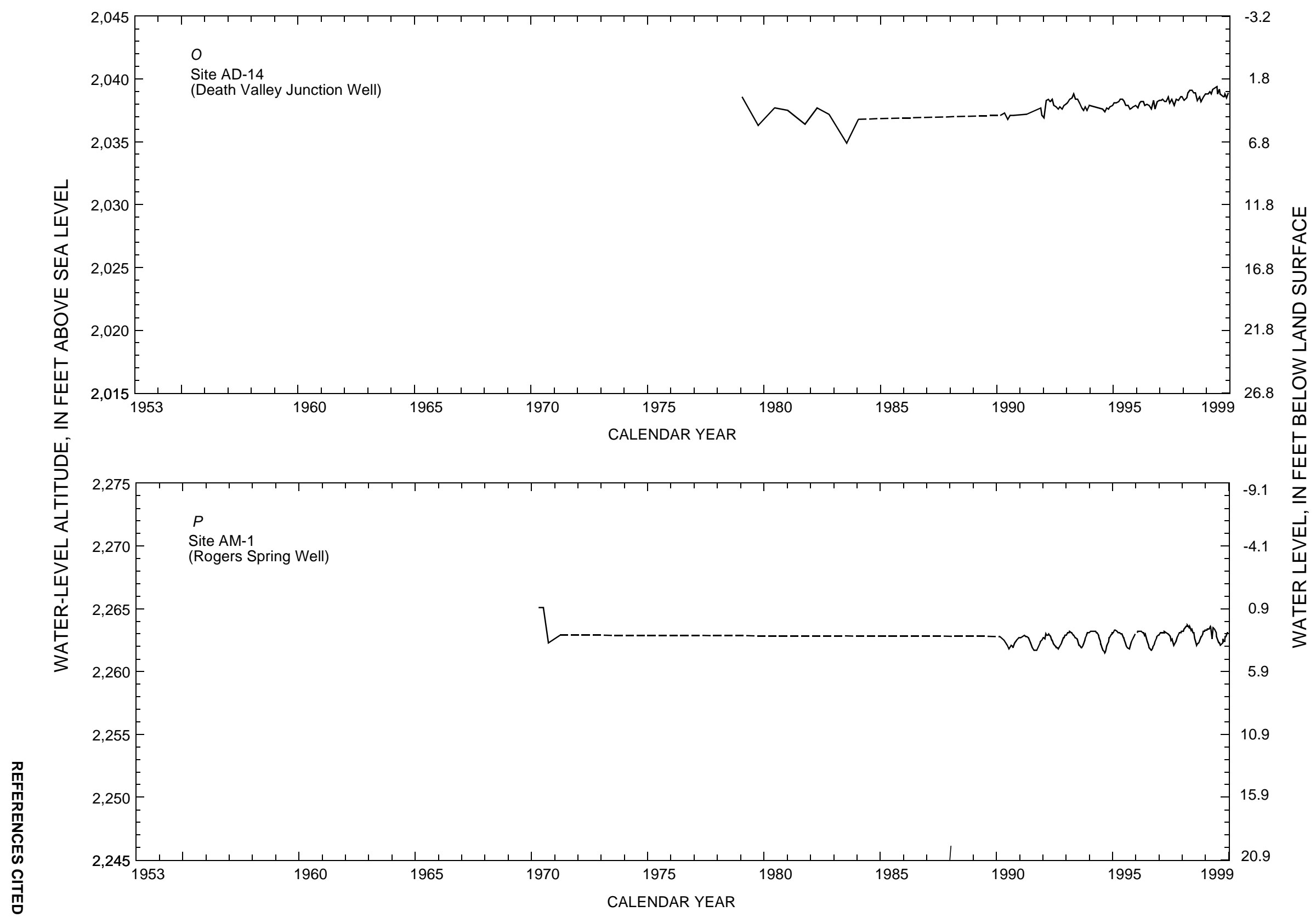

$\mathscr{\bullet}$

Figure 4. Continued. 


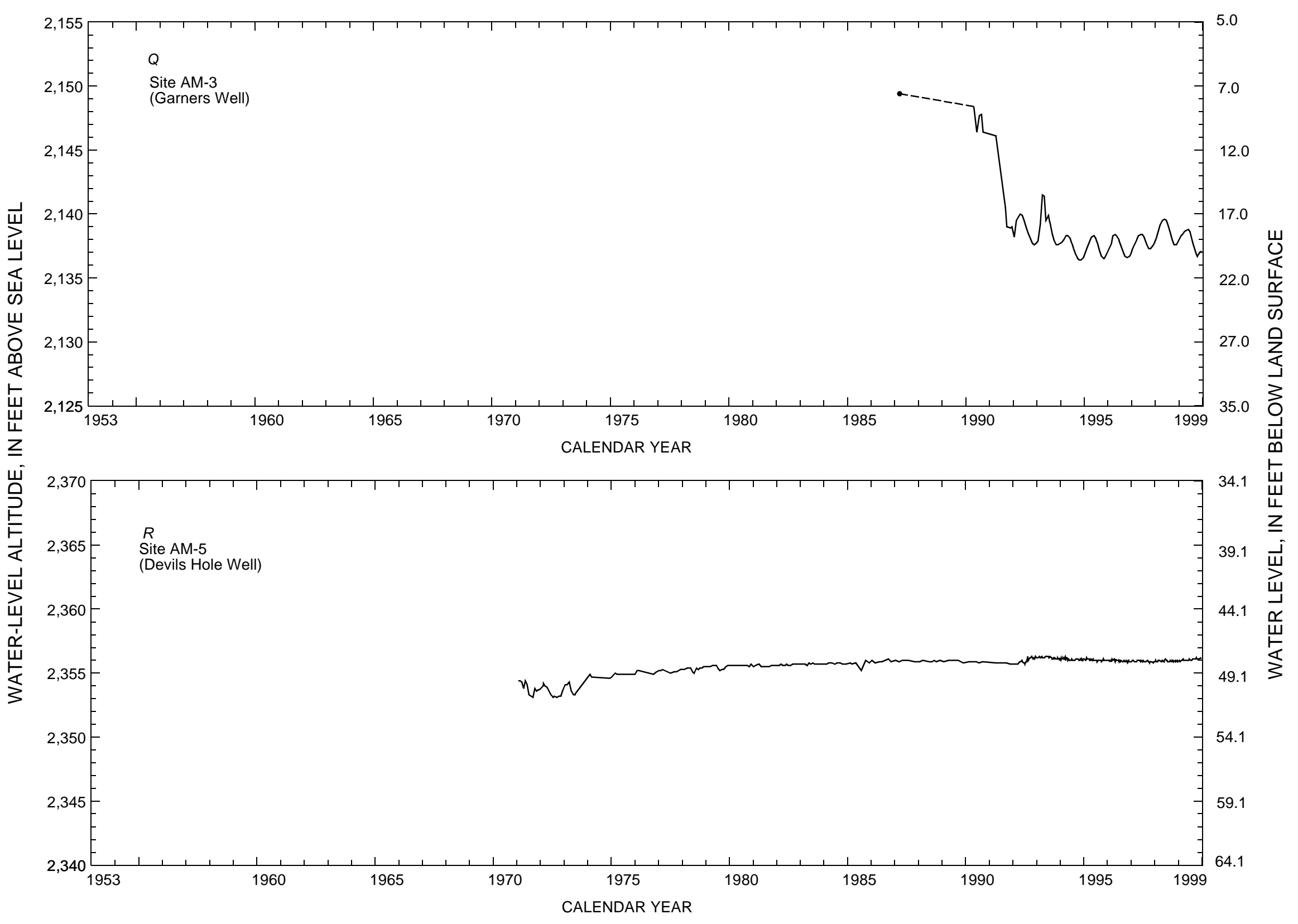

Figure 4. Continued. 


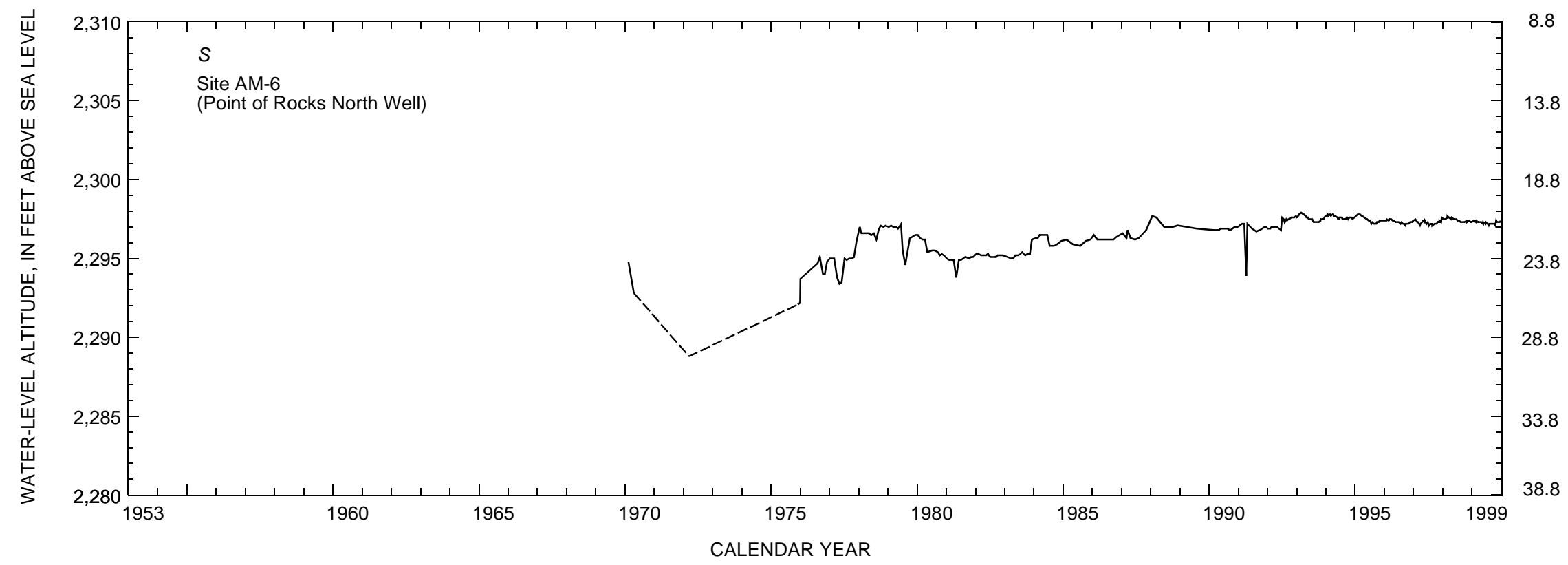

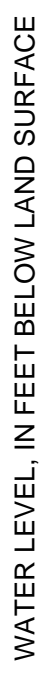

Figure 4. Continued. 


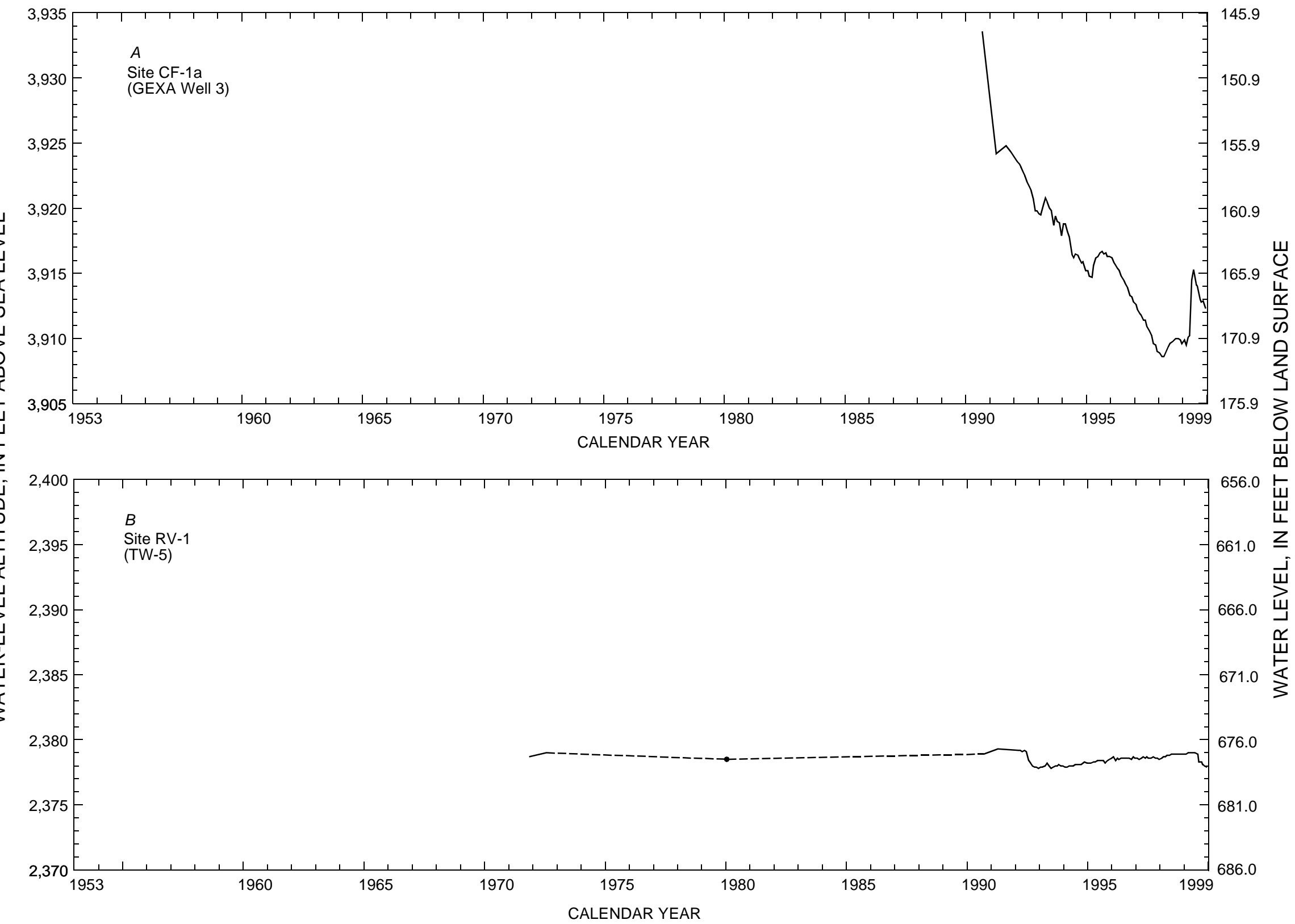

Figure 5. Periodic water levels through 1999 for selected sites at which primary contributing units are undifferentiated sedimentary rock. Lines connect periodic data presented in this and previous reports on selected ground-water data for Yucca Mountain region. Solid lines connect yearly or more frequent measurements. Lines are dashed where measurements were not available for consecutive calendar years. A solid dot is a single isolated measurement. Data that may represent short-term conditions at a site have been excluded (see section "Presentation of Ground-Water Data"). 


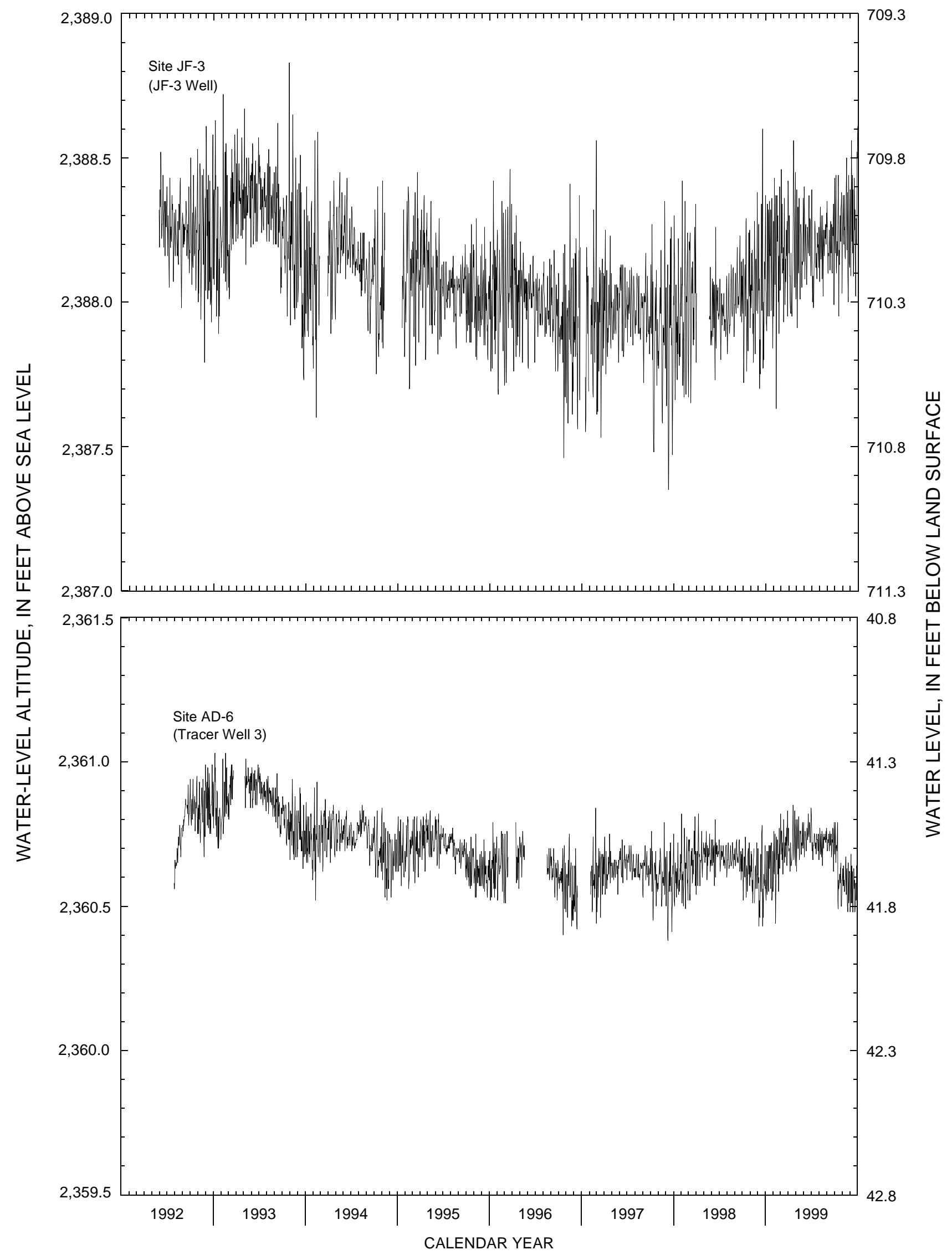

Figure 6

AD-6, July 1992 through December 1999 


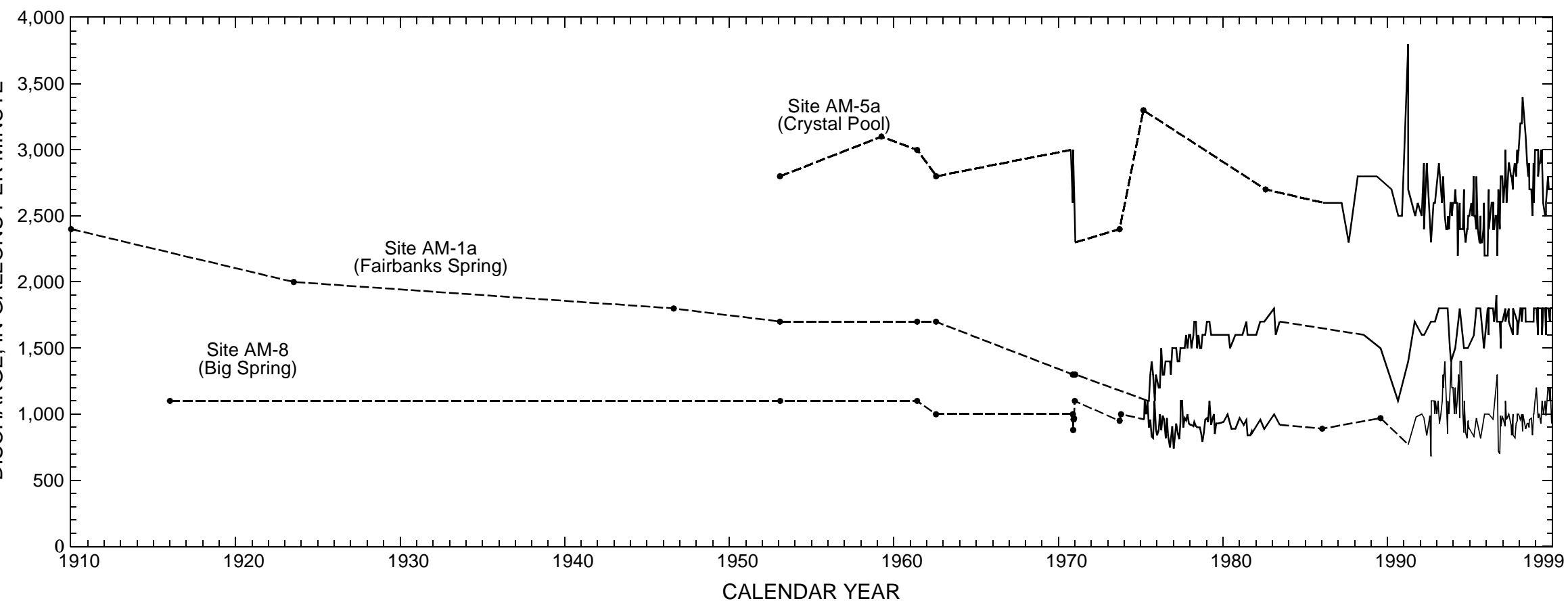

Figure 7. Discharge at sites AM-1a (Fairbanks Spring), AM-5a (Crystal Pool), and AM-8 (Big Spring) through 1999. Lines connect periodic measurements presented in this and previous reports on selected ground-water data for Yucca Mountain region. Solid lines connect yearly or more frequent measurements. Lines are dashed where measurements were not available for consecutive calendar years. A solid dot is a single isolated measurement. 


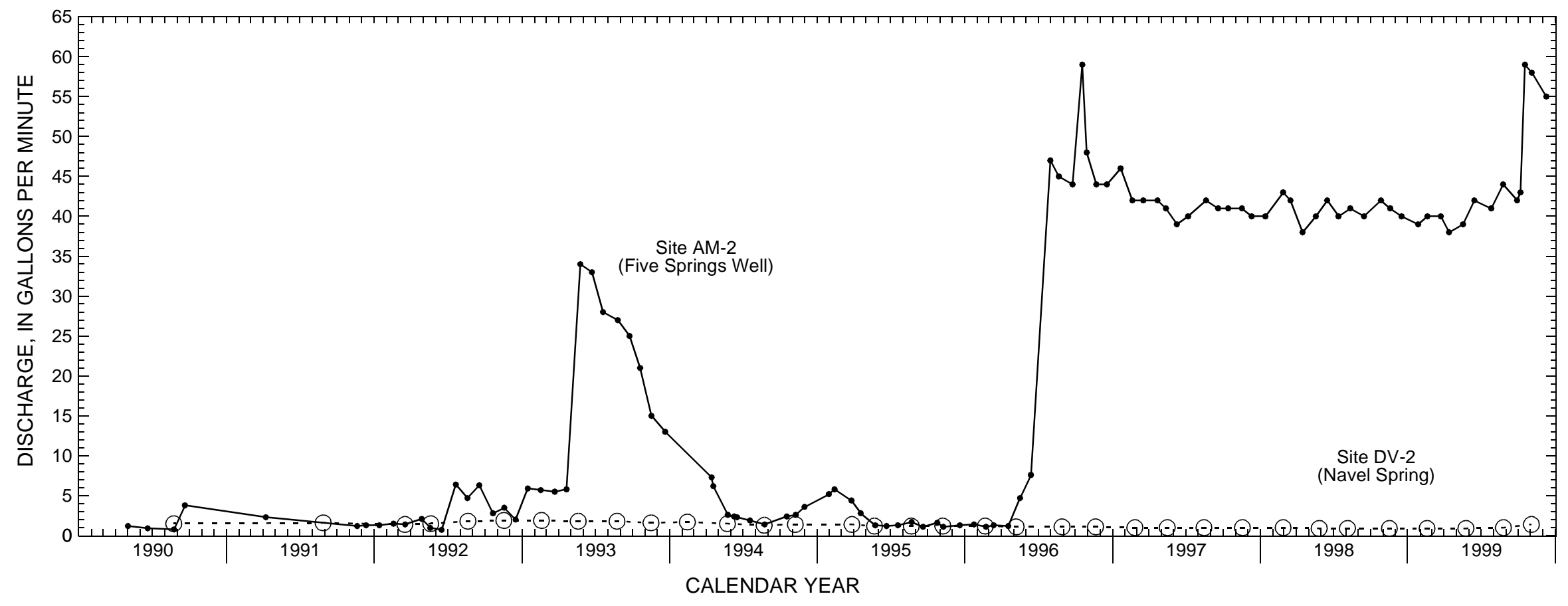

Figure 8. Discharge at sites AM-2 (Five Springs Well) and DV-2 (Navel Spring), 1990 through 1999. Symbols indicate periodic measurements presented in this and previous reports on selected ground-water data for Yucca Mountain region. 


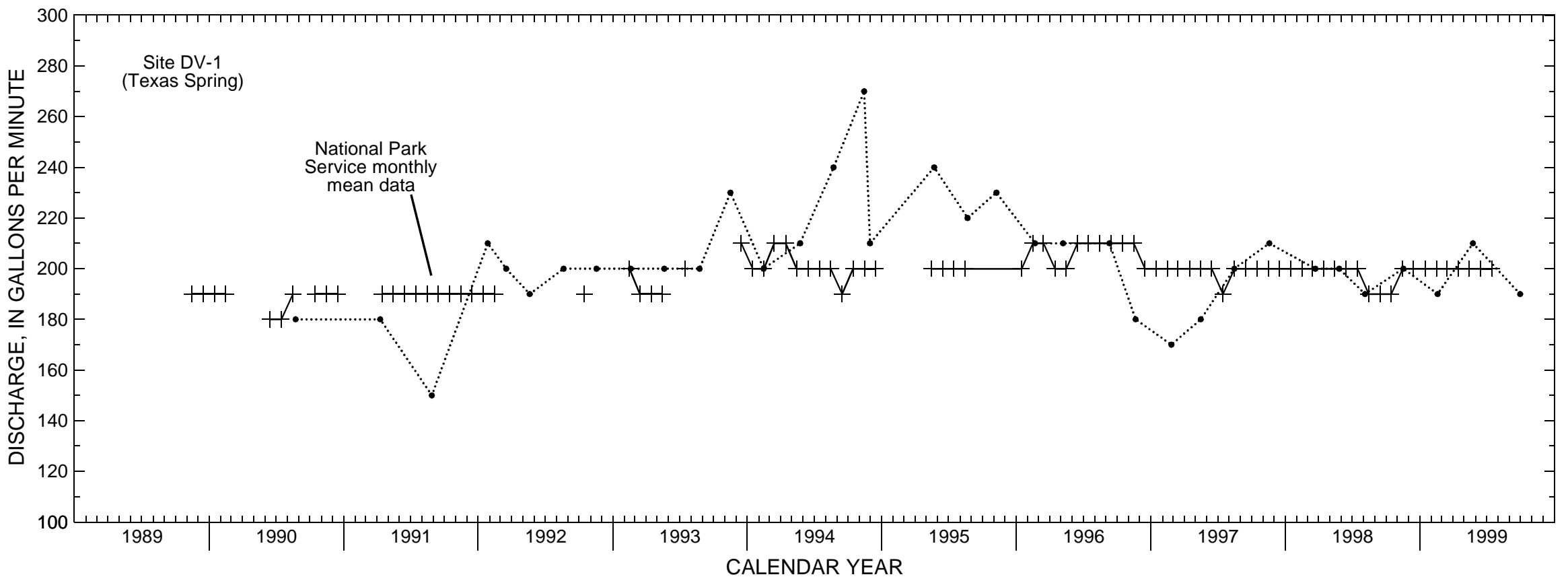

Figure 9. Discharge at site DV-1 (Texas Spring), 1989 through 1999. Dots indicate discrete USGS measurements presented in this and previous reports on selected ground-water data for Yucca Mountain region; periodic measurements for 1990-92 have been revised from those tabulated by La Camera and Westenburg (1994, table 5) to reflect water previously unaccounted for at the site. Plus symbols represent National Park Service monthly mean data for any given month and are not connected by a line where that data are not available for consecutive months. Differences between periodic measurements and monthly means may be due to sitespecific conditions that affect accuracy of the measurement methods used. Accuracy of periodic measurements is limited by unmeasurable flow near the walls of the flume, an unequal distribution of velocities in the limited width of the measurement section, and a large percentage of total flow contained in each measurable portion of flow. 


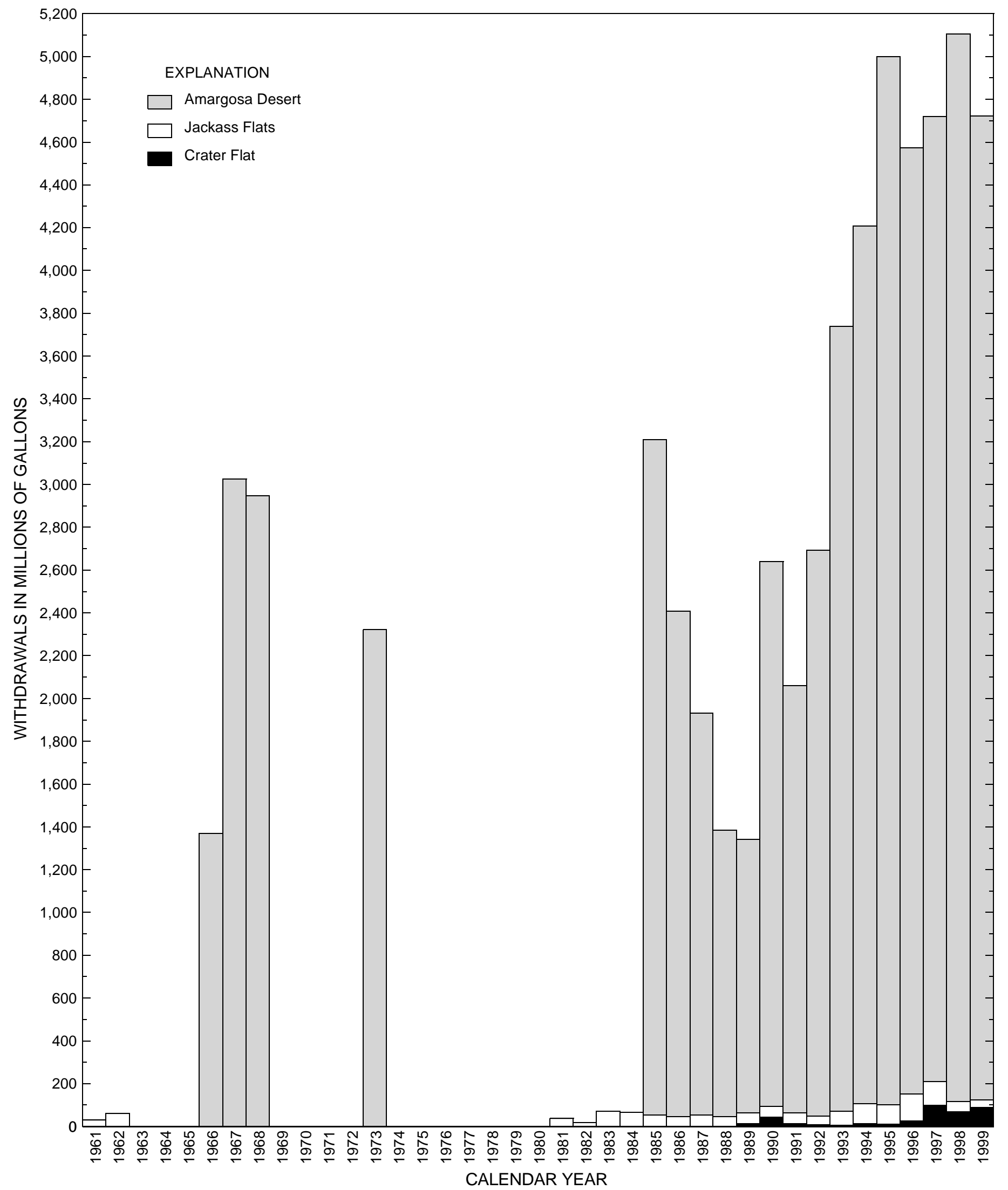

Figure 10. Available estimates of annual ground-water withdrawals for selected areas within Alkali Flat-Furnace Creek Ranch ground-water subbasin, 1961 through 1999. 


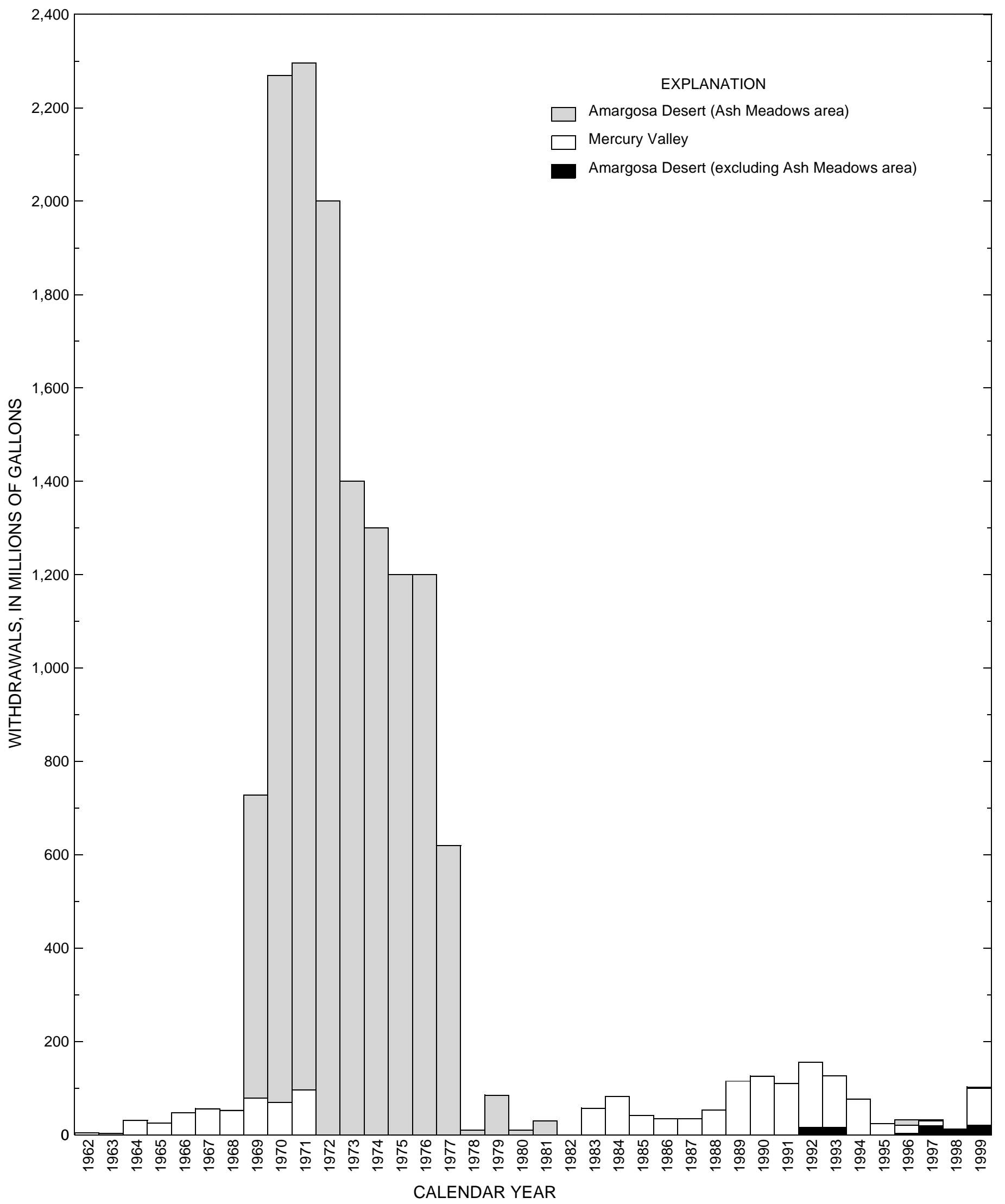

Figure 11. Available estimates of annual ground-water withdrawals for selected areas within Ash Meadows ground-water subbasin, 1962 through 1999. 


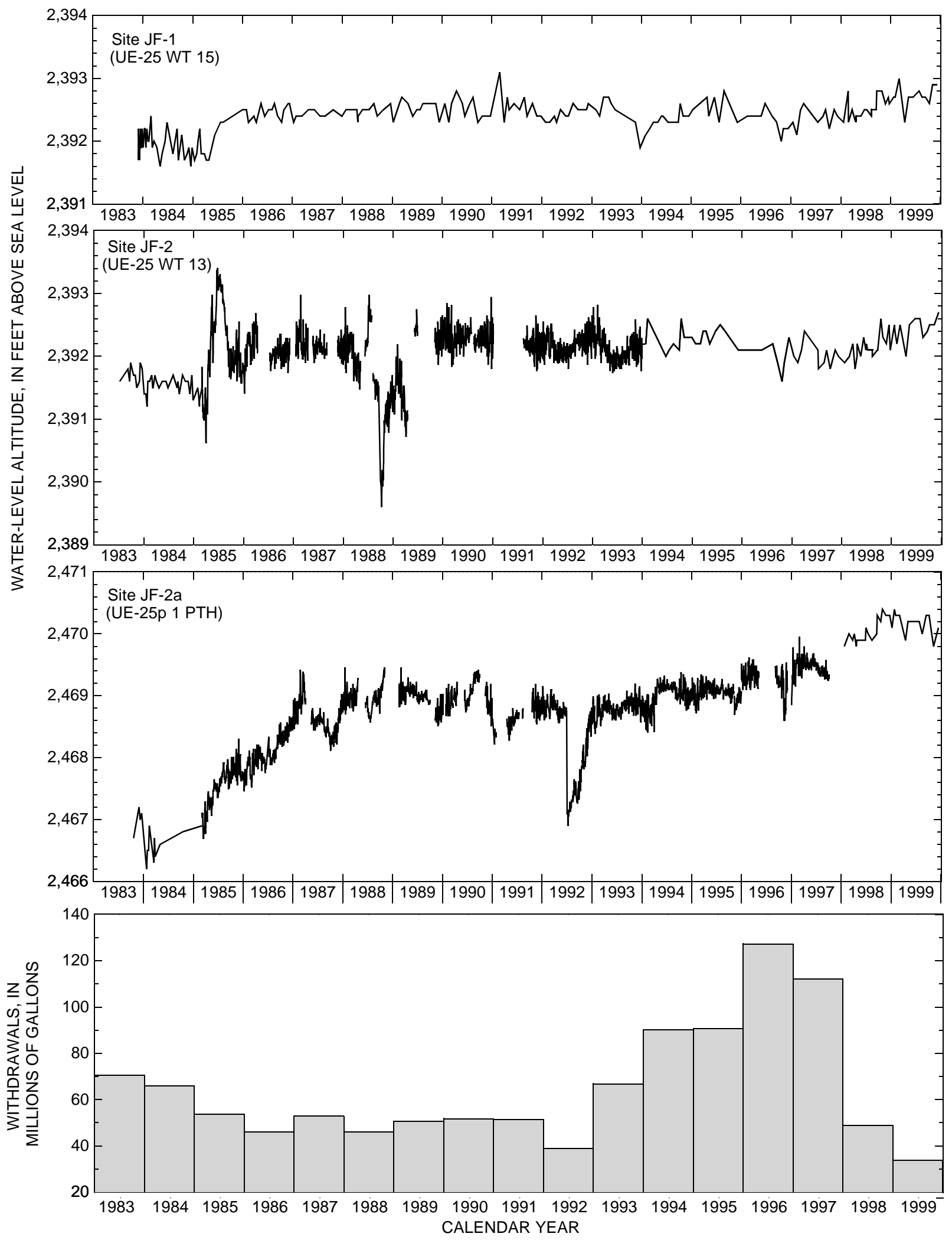

Figure 12. Water-level altitudes in wells JF-1, JF-2, JF-2a, J-13, J-11, J-12, and JF-3, and estimated annual ground-water withdrawals from Jackass Flats, 1983 through 1999. Lines connect periodic measurements or daily average water levels (when continual data recorded by instrumentation were available for more than half a year). Solid lines connect yearly or more frequent measurements. Lines are dashed where measurements were not available for consecutive calendar years. A solid dot is a single isolated measurement. Periodic measurements that may reflect short-term conditions at a site have been excluded (see section "Discussion of Ground-Water Levels and Ground-Water Withdrawals in Jackass Flats"). 

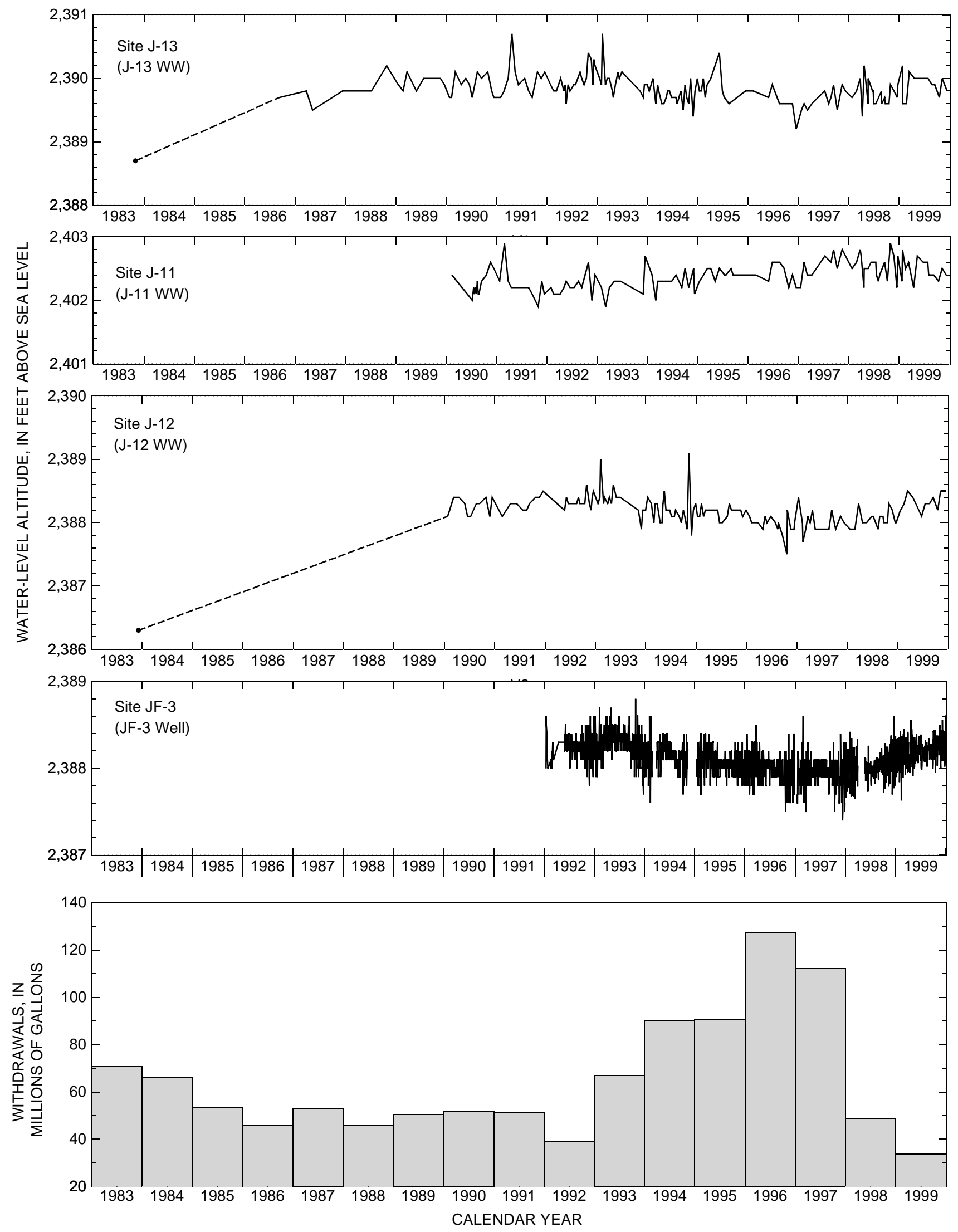

Figure 12. Continued. 


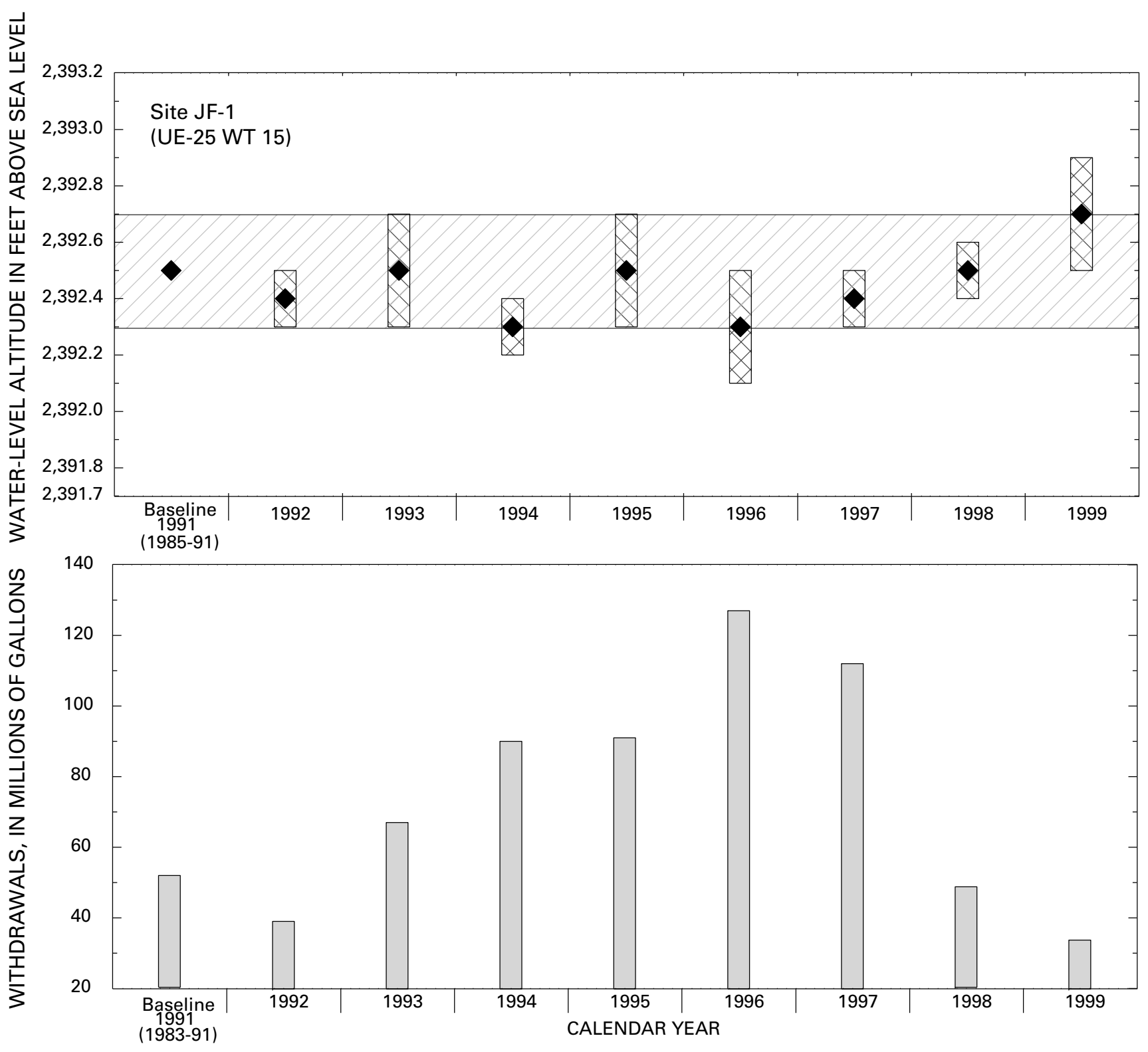

\section{EXPLANATION}

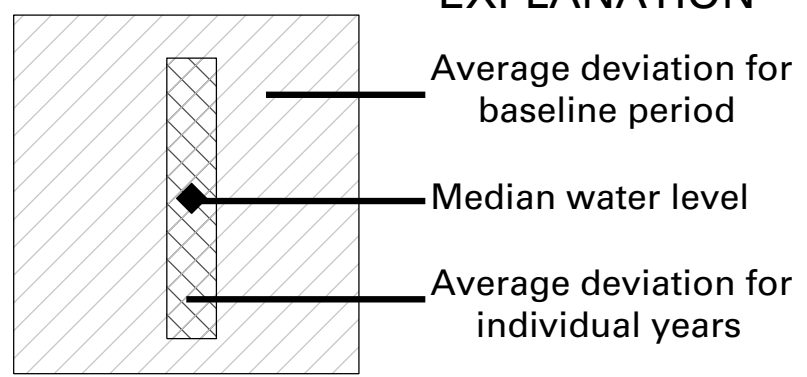

Figure 13. Median water-level altitudes and average deviation of water levels for wells JF-1, JF-2, JF-2a, J-13, $\mathrm{J}-11, \mathrm{~J}-12$, and JF-3, and estimated annual ground-water withdrawals from Jackass Flats, for selected baseline periods and for calendar years 1992 through 1999. Statistical data for individual years included in baseline periods are not shown. 

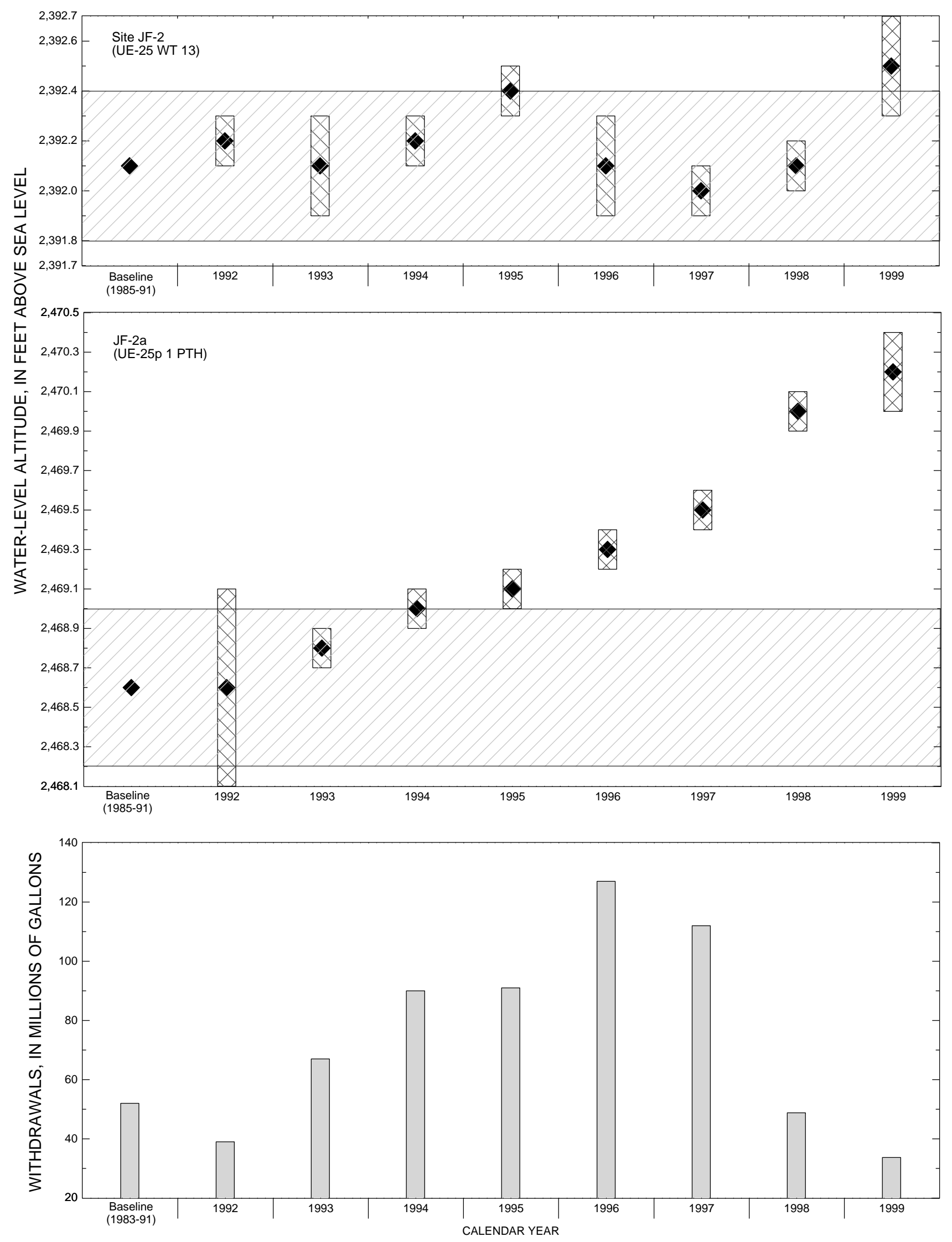

Figure 13. Continued. 

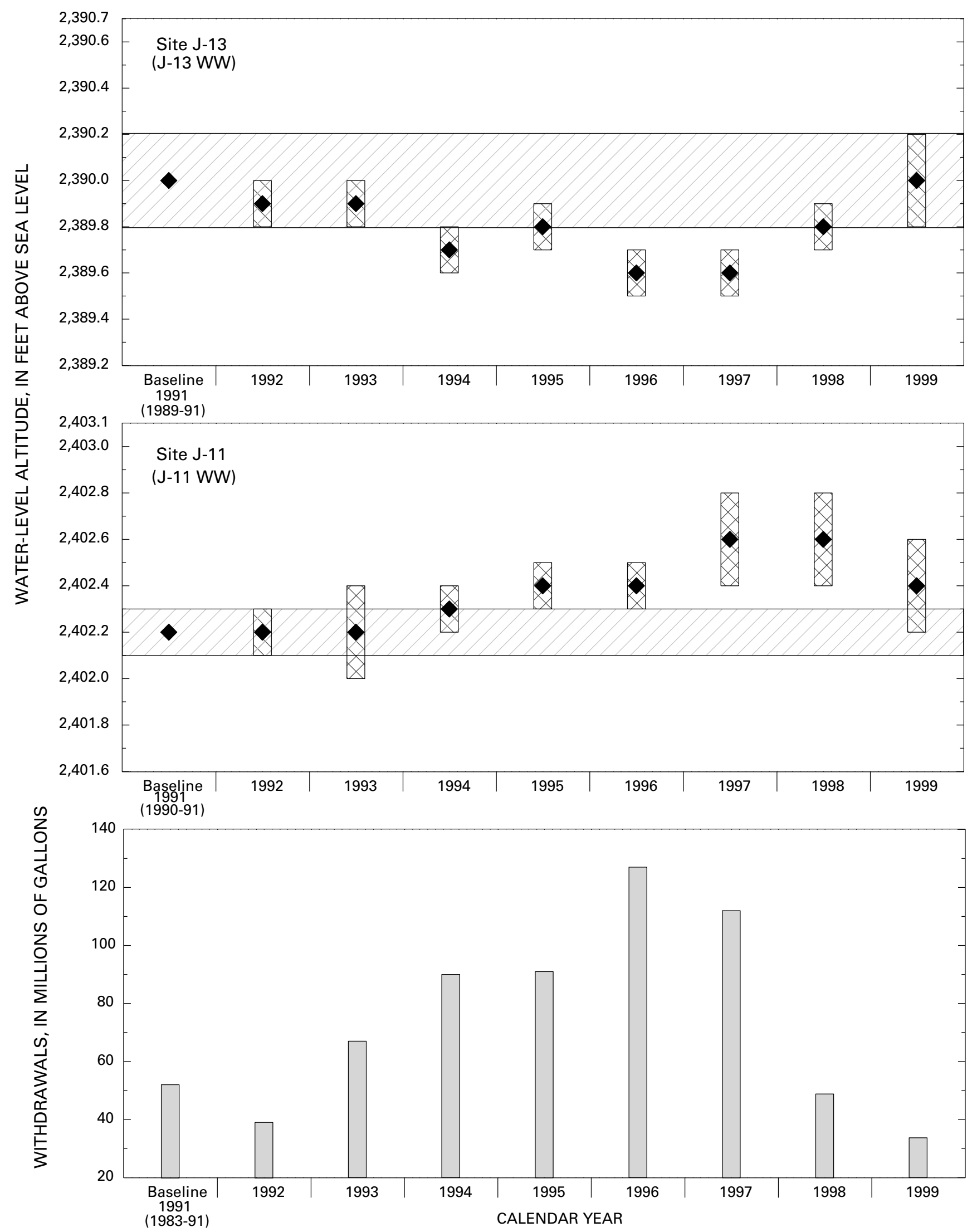

Figure 13. Continued. 

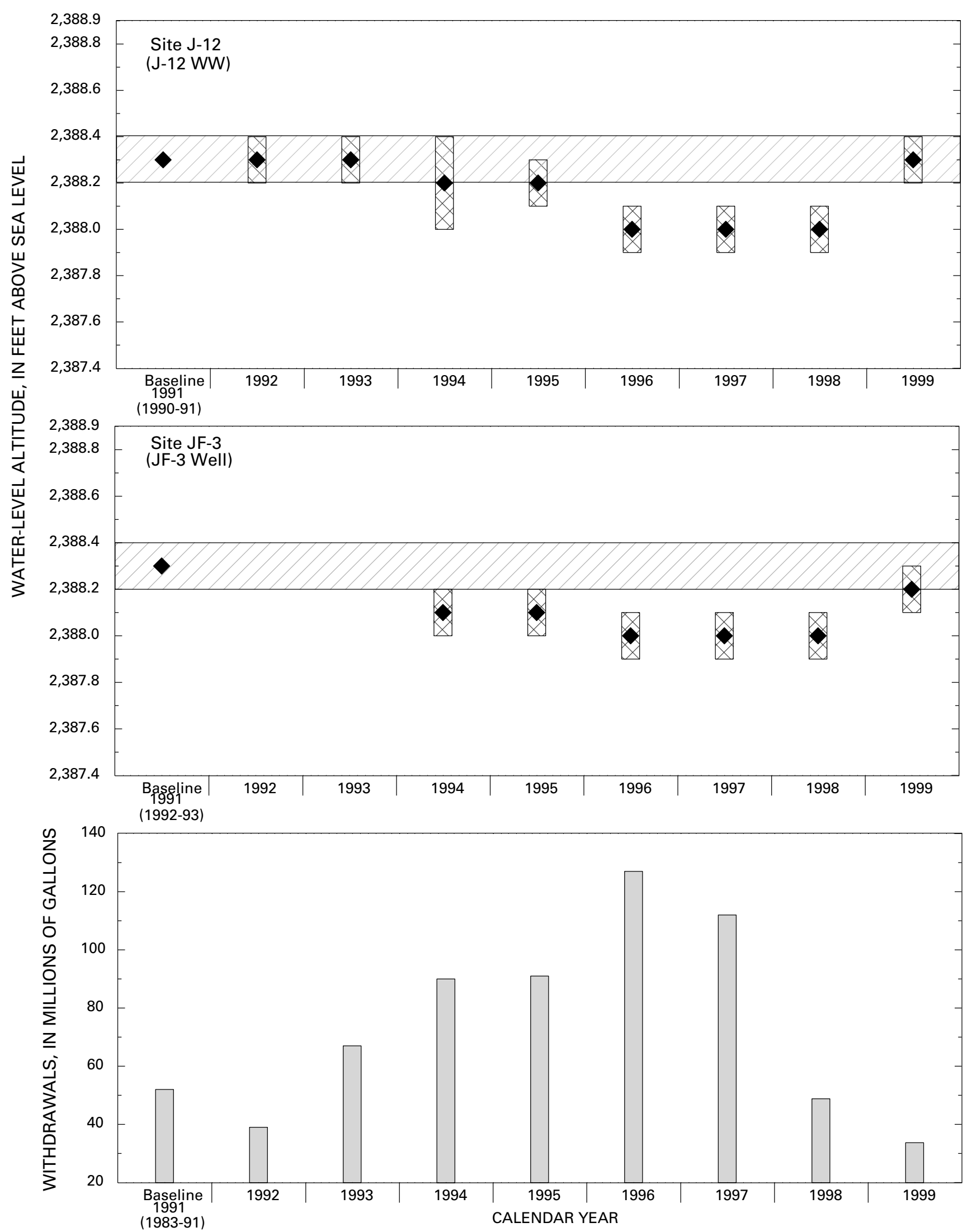

Figure 13. Continued. 
Table 5. Periodic water-level data at monitoring sites in Yucca Mountain region for calendar year 1999

Site number: Sites are grouped by hydrographic area and, within each area, are listed in general north-to-south, then west-to-east order. See section "Site Number" for further discussion.

U.S. Geological Survev site identification: Unique identification number for site as stored in files and data bases of U.S. Geological Survey (USGS).

Land-surface altitude: Altitude of land surface in vicinity of site. Exception is altitude for site AM-4, which is altitude of bolt that serves as measurement point. Altitudes are reported to nearest 0.1 foot and were derived from USGS land surveys.

Height of measurement point: Height of measurement point (MP) most recently used. MP is stable, recoverable point from which periodic measurements to depth of water are made. MP at site AM-4 is bolt fastened to south wall of fissure, and is not referenced to land surface. Negative number indicates MP is below land surface.

Depth to water: Depths listed generally represent water level below land surface. An exception is site AM-4, where data represent water levels below measurement point. Apparent differences in depth to water at sites that list data from several sources may result from differing estimates of distance from land surface to measurement point used.

Method: Method used to measure depth to water. N, ruled tape; R, reported; S, steel tape; T, electric tape; V, calibrated electric tape.

Site status: Known conditions at site that may have affected measured depth to water. F, flowing; P, pumping; Z, measurement made in pump-discharge column.

Data source: EMP, Environmental-Monitoring Program (USGS); NDWR, Nevada Division of Water Resources; NPS, National Park Service; PVT, private owner; SCP, Site Characterization Project (USGS); USFWS, U.S. Fish \& Wildlife Service; USGS-NV, other Nevada District programs.

\begin{tabular}{|c|c|c|c|c|c|c|c|c|c|c|c|}
\hline \multirow[b]{2}{*}{$\begin{array}{c}\text { Site } \\
\text { number } \\
\text { (fig. 1) }\end{array}$} & \multirow[b]{2}{*}{$\begin{array}{l}\text { U.S. Geological } \\
\text { Survey site } \\
\text { identification }\end{array}$} & \multirow[b]{2}{*}{ Site name } & \multirow[b]{2}{*}{$\begin{array}{c}\text { Land-surface } \\
\text { altitude } \\
\text { (feet above } \\
\text { sea level) }\end{array}$} & \multirow[b]{2}{*}{$\begin{array}{l}\text { Height of } \\
\text { measurement } \\
\text { point (feet } \\
\text { above land } \\
\text { surface) }\end{array}$} & \multicolumn{7}{|c|}{ Water-level measurement } \\
\hline & & & & & Date & Time & $\begin{array}{l}\text { Depth to water } \\
\text { (feet below } \\
\text { land } \\
\text { surface) }\end{array}$ & $\begin{array}{c}\text { Altitude of } \\
\text { water surface } \\
\text { (feet above } \\
\text { sea level) }\end{array}$ & Method & $\begin{array}{l}\text { Site } \\
\text { status }\end{array}$ & $\begin{array}{l}\text { Data } \\
\text { source }\end{array}$ \\
\hline \multirow[t]{12}{*}{ CF-1a } & 365445116383901 & GEXA Well 3 & $4,080.9$ & 1.68 & 01-26-1999 & 1142 & 170.95 & $3,910.0$ & S & - & EMP \\
\hline & & & & & 02-23-1999 & 0756 & 171.37 & $3,909.5$ & S & - & EMP \\
\hline & & & & & 03-24-1999 & 1046 & 170.80 & $3,910.1$ & S & - & EMP \\
\hline & & & & & 04-14-1999 & 0928 & 170.74 & $3,910.2$ & S & - & EMP \\
\hline & & & & & 05-19-1999 & 0925 & 166.36 & $3,914.5$ & S & - & EMP \\
\hline & & & & & 06-16-1999 & 0915 & 165.61 & $3,915.3$ & S & - & EMP \\
\hline & & & & & 07-27-1999 & 1820 & 166.81 & $3,914.1$ & S & - & EMP \\
\hline & & & & & 08-09-1999 & 1253 & 166.91 & $3,914.0$ & S & - & EMP \\
\hline & & & & & 09-24-1999 & 1337 & 167.86 & $3,913.0$ & S & - & EMP \\
\hline & & & & & 10-07-1999 & 0901 & 168.09 & $3,912.8$ & S & - & EMP \\
\hline & & & & & 11-04-1999 & 1443 & 168.03 & $3,912.9$ & S & - & EMP \\
\hline & & & & & 12-13-1999 & 1313 & 168.62 & $3,912.3$ & S & - & EMP \\
\hline \multirow[t]{10}{*}{$\mathrm{CF}-2$} & 364732116330701 & USWVH-1 & $3,161.1$ & 1.17 & 01-20-1999 & 0900 & 603.59 & $2,557.5$ & S & - & SCP \\
\hline & & & & & 02-02-1999 & 1426 & 603.67 & $2,557.4$ & S & - & SCP \\
\hline & & & & & 03-09-1999 & 1412 & 603.60 & $2,557.5$ & S & - & SCP \\
\hline & & & & & 04-19-1999 & 1410 & 603.58 & $2,557.5$ & S & - & SCP \\
\hline & & & & & 05-03-1999 & 1342 & 603.47 & $2,557.6$ & S & - & SCP \\
\hline & & & & & 06-21-1999 & 1430 & 603.50 & $2,557.6$ & S & - & SCP \\
\hline & & & & & 07-27-1999 & 1148 & 603.68 & $2,557.4$ & S & - & $\mathrm{SCP}$ \\
\hline & & & & & 08-17-1999 & 0853 & 603.76 & $2,557.3$ & S & - & SCP \\
\hline & & & & & 09-16-1999 & 1008 & 603.68 & $2,557.4$ & S & - & SCP \\
\hline & & & & & 10-19-1999 & 0906 & 603.74 & $2,557.4$ & S & - & SCP \\
\hline
\end{tabular}


Table 5. Periodic water-level data at monitoring sites in Yucca Mountain region for calendar year 1999—Continued

\begin{tabular}{|c|c|c|c|c|c|c|c|c|c|c|c|}
\hline \multirow{2}{*}{$\begin{array}{lc} & \\
\infty & \text { Site } \\
\frac{D}{\Phi} & \text { number } \\
\frac{D}{0} & \text { (fig. 1) } \\
\frac{D}{2} & \end{array}$} & \multirow[b]{2}{*}{$\begin{array}{l}\text { U.S. Geological } \\
\text { Survey site } \\
\text { identification }\end{array}$} & \multirow[b]{2}{*}{ Site name } & \multirow[b]{2}{*}{$\begin{array}{c}\text { Land-surface } \\
\text { altitude } \\
\text { (feet above } \\
\text { sea level) }\end{array}$} & \multirow[b]{2}{*}{$\begin{array}{l}\text { Height of } \\
\text { measurement } \\
\text { point (feet } \\
\text { above land } \\
\text { surface) }\end{array}$} & \multicolumn{7}{|c|}{ Water-level measurement } \\
\hline & & & & & Date & Time & $\begin{array}{l}\text { Depth to water } \\
\text { (feet below } \\
\text { land } \\
\text { surface) }\end{array}$ & $\begin{array}{c}\text { Altitude of } \\
\text { water surface } \\
\text { (feet above } \\
\text { sea level) }\end{array}$ & Method & $\begin{array}{c}\text { Site } \\
\text { status }\end{array}$ & $\begin{array}{l}\text { Data } \\
\text { source }\end{array}$ \\
\hline CF-2 & 364732116330701 & USWVH-1 & $3,161.1$ & 1.17 & 11-16-1999 & 1012 & 603.61 & $2,557.5$ & $\mathrm{~S}$ & - & SCP \\
\hline & & & & & $12-15-1999$ & 0958 & 603.85 & $2,557.2$ & $\mathrm{~S}$ & - & $\mathrm{SCP}$ \\
\hline CF-3 & 364105116302601 & Cind-R-Lite Well & $2,725.6$ & -3.20 & 01-26-1999 & 1348 & 331.42 & $2,394.2$ & $\mathrm{~S}$ & - & EMP \\
\hline & & & & & 02-25-1999 & 0855 & 331.55 & $2,394.0$ & $\mathrm{~S}$ & - & EMP \\
\hline & & & & & 03-24-1999 & 1250 & 331.46 & $2,394.1$ & $\mathrm{~S}$ & - & EMP \\
\hline & & & & & 04-14-1999 & 1115 & 331.52 & $2,394.1$ & $\mathrm{~S}$ & - & EMP \\
\hline & & & & & 05-19-1999 & 1110 & 331.55 & $2,394.0$ & S & - & EMP \\
\hline & & & & & 06-16-1999 & 1125 & 331.50 & $2,394.1$ & $\mathrm{~S}$ & - & EMP \\
\hline & & & & & 07-28-1999 & 1120 & 331.41 & $2,394.2$ & S & - & EMP \\
\hline & & & & & 08-09-1999 & 1138 & 331.33 & $2,394.3$ & $\mathrm{~S}$ & - & EMP \\
\hline & & & & & 09-24-1999 & 1106 & 331.41 & $2,394.2$ & $S$ & - & EMP \\
\hline & & & & & 10-07-1999 & 1142 & 331.50 & $2,394.1$ & $\mathrm{~S}$ & - & EMP \\
\hline & & & & & 11-04-1999 & 1331 & 331.33 & $2,394.3$ & $\mathrm{~S}$ & - & EMP \\
\hline & & & & & 12-13-1999 & 1219 & 331.32 & $2,394.3$ & S & - & EMP \\
\hline JF-1 & 365116116233801 & UE-25 WT 15 & $3,553.8$ & 0.18 & 01-21-1999 & 1238 & $1,161.13$ & $2,392.7$ & $S$ & - & $\mathrm{SCP}$ \\
\hline & & & & & 02-03-1999 & 1410 & $1,161.11$ & $2,392.7$ & $\mathrm{~S}$ & - & $\mathrm{SCP}$ \\
\hline & & & & & 03-03-1999 & 1326 & $1,160.84$ & $2,393.0$ & $\mathrm{~S}$ & - & SCP \\
\hline & & & & & 04-15-1999 & 1254 & $1,161.46$ & $2,392.3$ & $\mathrm{~S}$ & - & SCP \\
\hline & & & & & 05-12-1999 & 1259 & $1,161.07$ & $2,392.7$ & $S$ & - & $\mathrm{SCP}$ \\
\hline & & & & & 06-15-1999 & 0821 & $1,161.14$ & $2,392.7$ & $\mathrm{~S}$ & - & SCP \\
\hline & & & & & 07-28-1999 & 1551 & $1,161.03$ & $2,392.8$ & $\mathrm{~S}$ & - & SCP \\
\hline & & & & & 08-19-1999 & 1032 & $1,161.14$ & $2,392.7$ & $\mathrm{~S}$ & - & SCP \\
\hline & & & & & 09-13-1999 & 1142 & $1,161.13$ & $2,392.7$ & $\mathrm{~S}$ & - & SCP \\
\hline & & & & & $10-12-1999$ & 1321 & $1,161.22$ & $2,392.6$ & $S$ & - & SCP \\
\hline & & & & & 11-04-1999 & 1510 & $1,160.95$ & $2,392.8$ & $\mathrm{~S}$ & - & $\mathrm{SCP}$ \\
\hline & & & & & 12-09-1999 & 1535 & $1,160.90$ & $2,392.9$ & $\mathrm{~S}$ & - & SCP \\
\hline JF-2 & 364945116235001 & UE-25 WT 13 & $3,387.5$ & 1.00 & 01-21-1999 & 1314 & 995.03 & $2,392.5$ & $\mathrm{~S}$ & - & SCP \\
\hline & & & & & 01-25-1999 & 0816 & 995.05 & $2,392.4$ & $\mathrm{~S}$ & - & SCP \\
\hline & & & & & 02-10-1999 & 1506 & 995.27 & $2,392.2$ & $\mathrm{~S}$ & - & $\mathrm{SCP}$ \\
\hline & & & & & 03-05-1999 & 1536 & 995.01 & $2,392.5$ & S & - & $\mathrm{SCP}$ \\
\hline & & & & & 04-16-1999 & 1516 & 995.48 & $2,392.0$ & $S$ & - & $\mathrm{SCP}$ \\
\hline & & & & & 05-12-1999 & 1407 & 994.97 & $2,392.5$ & $\mathrm{~S}$ & - & SCP \\
\hline & & & & & $06-22-1999$ & 1230 & 994.89 & $2,392.6$ & $\mathrm{~S}$ & - & SCP \\
\hline & & & & & 07-29-1999 & 1042 & 994.94 & $2,392.6$ & S & - & SCP \\
\hline & & & & & 08-19-1999 & 1138 & 995.17 & $2,392.3$ & $S$ & - & SCP \\
\hline & & & & & 09-20-1999 & 1146 & 995.15 & $2,392.4$ & $\mathrm{~S}$ & - & $\mathrm{SCP}$ \\
\hline
\end{tabular}




\begin{tabular}{|c|c|c|c|c|c|c|c|c|c|c|c|}
\hline \multirow[b]{2}{*}{$\begin{array}{c}\text { Site } \\
\text { number } \\
\text { (fig. 1) }\end{array}$} & \multirow[b]{2}{*}{$\begin{array}{l}\text { U.S. Geological } \\
\text { Survey site } \\
\text { identification }\end{array}$} & \multirow[b]{2}{*}{ Site name } & \multirow[b]{2}{*}{$\begin{array}{l}\text { Land-surface } \\
\text { altitude } \\
\text { (feet above } \\
\text { sea level) }\end{array}$} & \multirow{2}{*}{$\begin{array}{l}\text { Height of } \\
\text { measurement } \\
\text { point (feet } \\
\text { above land } \\
\text { surface) }\end{array}$} & \multicolumn{7}{|c|}{ Water-level measurement } \\
\hline & & & & & Date & Time & $\begin{array}{l}\text { Depth to water } \\
\text { (feet below } \\
\text { land } \\
\text { surface) }\end{array}$ & $\begin{array}{c}\text { Altitude of } \\
\text { water surface } \\
\text { (feet above } \\
\text { sea level) }\end{array}$ & Method & $\begin{array}{c}\text { Site } \\
\text { status }\end{array}$ & $\begin{array}{l}\text { Data } \\
\text { source }\end{array}$ \\
\hline \multirow[t]{3}{*}{$\mathrm{JF}-2$} & 364945116235001 & UE-25 WT 13 & $3,387.5$ & 1.00 & 10-07-1999 & 1213 & 995.02 & $2,392.5$ & $\mathrm{~S}$ & - & $\mathrm{SCP}$ \\
\hline & & & & & 11-10-1999 & 1108 & 995.00 & $2,392.5$ & S & - & $\mathrm{SCP}$ \\
\hline & & & & & 12-13-1999 & 1426 & 994.76 & $2,392.7$ & S & - & $\mathrm{SCP}$ \\
\hline \multirow[t]{13}{*}{$J F-2 a$} & 364938116252102 & UE-25p 1 PTH & $3,655.5$ & 0.56 & 01-07-1999 & 1514 & $1,185.37$ & $2,470.1$ & $\mathrm{~S}$ & - & SCP \\
\hline & & & & & 01-25-1999 & 0952 & $1,185.13$ & $2,470.4$ & $\mathrm{~V}$ & - & EMP \\
\hline & & & & & 02-04-1999 & 1059 & $1,185.24$ & $2,470.3$ & S & - & SCP \\
\hline & & & & & 03-03-1999 & 1423 & $1,185.21$ & $2,470.3$ & S & - & SCP \\
\hline & & & & & 04-15-1999 & 1346 & $1,185.61$ & $2,469.9$ & S & - & SCP \\
\hline & & & & & 05-04-1999 & 1149 & $1,185.25$ & $2,470.2$ & $\mathrm{~S}$ & - & SCP \\
\hline & & & & & 06-17-1999 & 1157 & $1,185.29$ & $2,470.2$ & S & - & SCP \\
\hline & & & & & 07-26-1999 & 1407 & $1,185.28$ & $2,470.2$ & S & - & SCP \\
\hline & & & & & 08-16-1999 & 1552 & $1,185.49$ & $2,470.0$ & S & - & SCP \\
\hline & & & & & 09-15-1999 & 0948 & $1,185.19$ & $2,470.3$ & S & - & $\mathrm{SCP}$ \\
\hline & & & & & 10-06-1999 & 1102 & $1,185.16$ & $2,470.3$ & $\mathrm{~S}$ & - & SCP \\
\hline & & & & & 11-08-1999 & 1254 & $1,185.68$ & $2,469.8$ & S & - & SCP \\
\hline & & & & & 12-13-1999 & 1243 & $1,185.35$ & $2,470.2$ & S & - & $\mathrm{SCP}$ \\
\hline \multirow[t]{13}{*}{$\mathrm{J}-13$} & 364828116234001 & J-13 WW & $3,317.9$ & 1.11 & 01-25-1999 & 0916 & 927.68 & $2,390.2$ & $\mathrm{~V}$ & - & EMP \\
\hline & & & & & 01-27-1999 & 0922 & 928.28 & $2,389.6$ & S & - & $\mathrm{SCP}$ \\
\hline & & & & & 02-22-1999 & 0844 & 928.33 & $2,389.6$ & $S$ & - & $\mathrm{SCP}$ \\
\hline & & & & & 03-15-1999 & 1253 & 927.75 & $2,390.2$ & S & - & $\mathrm{SCP}$ \\
\hline & & & & & 04-20-1999 & 0916 & 927.89 & $2,390.0$ & $\mathrm{~S}$ & - & $\mathrm{SCP}$ \\
\hline & & & & & 05-13-1999 & 1520 & 927.88 & $2,390.0$ & $\mathrm{~S}$ & - & SCP \\
\hline & & & & & 06-21-1999 & 0738 & 927.89 & $2,390.0$ & S & - & SCP \\
\hline & & & & & 07-29-1999 & 0836 & 927.91 & $2,390.0$ & $\mathrm{~S}$ & - & $\mathrm{SCP}$ \\
\hline & & & & & 08-26-1999 & 1612 & 928.01 & $2,389.9$ & $\mathrm{~S}$ & - & SCP \\
\hline & & & & & 09-16-1999 & 0748 & 928.00 & $2,389.9$ & S & - & SCP \\
\hline & & & & & 10-20-1999 & 0808 & 928.16 & $2,389.7$ & S & - & SCP \\
\hline & & & & & 11-10-1999 & 0852 & 927.86 & $2,390.0$ & S & - & SCP \\
\hline & & & & & $12-15-1999$ & 0846 & 928.12 & $2,389.8$ & S & - & $\mathrm{SCP}$ \\
\hline \multirow[t]{10}{*}{$\mathrm{J}-11$} & 364706116170601 & J-11 WW & $3,442.8$ & 2.11 & 01-22-1999 & 0928 & $1,040.48$ & $2,402.3$ & $\mathrm{~S}$ & - & SCP \\
\hline & & & & & 01-25-1999 & 1045 & $1,039.96$ & $2,402.8$ & V & - & EMP \\
\hline & & & & & 02-17-1999 & 0849 & $1,040.35$ & $2,402.4$ & S & - & $\mathrm{SCP}$ \\
\hline & & & & & 03-10-1999 & 1552 & $1,040.21$ & $2,402.6$ & S & - & SCP \\
\hline & & & & & 04-16-1999 & 1604 & $1,040.55$ & $2,402.2$ & S & - & $\mathrm{SCP}$ \\
\hline & & & & & 05-13-1999 & 1428 & $1,040.10$ & $2,402.7$ & $\mathrm{~S}$ & - & SCP \\
\hline & & & & & 06-24-1999 & 1522 & $1,040.23$ & $2,402.6$ & S & - & SCP \\
\hline & & & & & 07-28-1999 & 1324 & $1,040.25$ & $2,402.6$ & S & - & $\mathrm{SCP}$ \\
\hline & & & & & 08-04-1999 & 0904 & $1,040.37$ & $2,402.4$ & $\mathrm{~S}$ & - & SCP \\
\hline & & & & & 09-07-1999 & 1014 & $1,040.40$ & $2,402.4$ & S & - & SCP \\
\hline
\end{tabular}


Table 5. Periodic water-level data at monitoring sites in Yucca Mountain region for calendar year 1999—Continued

\begin{tabular}{|c|c|c|c|c|c|c|c|c|c|c|c|}
\hline \multirow[b]{2}{*}{$\begin{array}{c}\text { Site } \\
\text { number } \\
\text { (fig. 1) }\end{array}$} & \multirow[b]{2}{*}{$\begin{array}{l}\text { U.S. Geological } \\
\text { Survey site } \\
\text { identification }\end{array}$} & \multirow[b]{2}{*}{ Site name } & \multirow[b]{2}{*}{$\begin{array}{l}\text { Land-surface } \\
\text { altitude } \\
\text { (feet above } \\
\text { sea level) }\end{array}$} & \multirow{2}{*}{$\begin{array}{l}\text { Height of } \\
\text { measurement } \\
\text { point (feet } \\
\text { above land } \\
\text { surface) }\end{array}$} & \multicolumn{7}{|c|}{ Water-level measurement } \\
\hline & & & & & Date & Time & $\begin{array}{l}\text { Depth to water } \\
\text { (feet below } \\
\text { land } \\
\text { surface) }\end{array}$ & $\begin{array}{c}\text { Altitude of } \\
\text { water surface } \\
\text { (feet above } \\
\text { sea level) }\end{array}$ & Method & $\begin{array}{c}\text { Site } \\
\text { status }\end{array}$ & $\begin{array}{c}\text { Data } \\
\text { source }\end{array}$ \\
\hline \multirow[t]{4}{*}{$\mathrm{J}-11$} & 364706116170601 & $\mathrm{~J}-11 \mathrm{WW}$ & $3,442.8$ & 2.11 & 10-13-1999 & 0852 & $1,040.47$ & $2,402.3$ & S & - & SCP \\
\hline & & & & & 10-13-1999 & 1041 & $1,040.47$ & $2,402.3$ & $\mathrm{~S}$ & - & SCP \\
\hline & & & & & 11-10-1999 & 1150 & $1,040.33$ & $2,402.5$ & $\mathrm{~S}$ & - & SCP \\
\hline & & & & & 12-08-1999 & 1416 & $1,040.43$ & $2,402.4$ & S & - & SCP \\
\hline \multirow[t]{12}{*}{$\mathrm{J}-12$} & 364554116232401 & $\mathrm{~J}-12 \mathrm{WW}$ & $3,128.4$ & 3.95 & 01-21-1999 & 0915 & 740.22 & $2,388.2$ & $\mathrm{~S}$ & - & SCP \\
\hline & & & & & 02-18-1999 & 1150 & 740.08 & $2,388.3$ & $\mathrm{~S}$ & - & SCP \\
\hline & & & & & 03-15-1999 & 1156 & 739.88 & $2,388.5$ & $\mathrm{~S}$ & - & $\mathrm{SCP}$ \\
\hline & & & & & 04-20-1999 & 1000 & 740.02 & $2,388.4$ & $\mathrm{~S}$ & - & SCP \\
\hline & & & & & 05-13-1999 & 0924 & 740.06 & $2,388.3$ & $\mathrm{~S}$ & - & $\mathrm{SCP}$ \\
\hline & & & & & 06-23-1999 & 1043 & 740.27 & $2,388.1$ & $\mathrm{~S}$ & - & SCP \\
\hline & & & & & 07-21-1999 & 1544 & 740.14 & $2,388.3$ & $\mathrm{~S}$ & - & SCP \\
\hline & & & & & 08-19-1999 & 0742 & 740.13 & $2,388.3$ & $\mathrm{~S}$ & - & SCP \\
\hline & & & & & 09-15-1999 & 1544 & 740.04 & $2,388.4$ & $\mathrm{~S}$ & - & SCP \\
\hline & & & & & 10-20-1999 & 1258 & 740.21 & $2,388.2$ & S & - & $\mathrm{SCP}$ \\
\hline & & & & & 11-08-1999 & 1514 & 739.89 & $2,388.5$ & $\mathrm{~S}$ & - & SCP \\
\hline & & & & & $12-13-1999$ & 1058 & 739.89 & $2,388.5$ & S & - & $\mathrm{SCP}$ \\
\hline \multirow[t]{12}{*}{$\mathrm{JF}-3$} & 364528116232201 & JF-3 Well & $3,098.3$ & 2.27 & 01-25-1999 & 1146 & 709.91 & $2,388.4$ & $\mathrm{~V}$ & - & EMP \\
\hline & & & & & 02-03-1999 & 0831 & 710.17 & $2,388.1$ & $\mathrm{~V}$ & - & EMP \\
\hline & & & & & 03-03-1999 & 0902 & 709.93 & $2,388.4$ & $\mathrm{~V}$ & - & EMP \\
\hline & & & & & 04-06-1999 & 0903 & 710.21 & $2,388.1$ & $\mathrm{~V}$ & - & EMP \\
\hline & & & & & 05-03-1999 & 1046 & 709.98 & $2,388.3$ & $\mathrm{~V}$ & - & EMP \\
\hline & & & & & 06-01-1999 & 1115 & 710.11 & $2,388.2$ & $\mathrm{~V}$ & - & EMP \\
\hline & & & & & 07-07-1999 & 0846 & 710.28 & $2,388.0$ & $\mathrm{~V}$ & - & EMP \\
\hline & & & & & 08-03-1999 & 0846 & 710.26 & $2,388.0$ & $\mathrm{~V}$ & - & EMP \\
\hline & & & & & 09-01-1999 & 0916 & 709.99 & $2,388.3$ & $\mathrm{~V}$ & - & EMP \\
\hline & & & & & 10-05-1999 & 0900 & 710.08 & $2,388.2$ & $\mathrm{~V}$ & - & EMP \\
\hline & & & & & 11-01-1999 & 0946 & 710.10 & $2,388.2$ & V & - & EMP \\
\hline & & & & & 12-14-1999 & 0846 & 710.25 & $2,388.0$ & $\mathrm{~V}$ & - & EMP \\
\hline \multirow[t]{10}{*}{ RV-1 } & 363815116175901 & TW-5 & 3056.0 & 1.6 & 01-26-1999 & 1445 & 677.09 & $2,378.9$ & $\mathrm{~V}$ & - & EMP \\
\hline & & & & & 02-25-1999 & 1050 & 677.03 & $2,379.0$ & $\mathrm{~V}$ & - & EMP \\
\hline & & & & & 03-24-1999 & 1418 & 677.00 & $2,379.0$ & V & - & EMP \\
\hline & & & & & 04-12-1999 & 1257 & 677.04 & $2,379.0$ & V & - & EMP \\
\hline & & & & & 05-19-1999 & 0725 & 676.99 & $2,379.0$ & $\mathrm{~V}$ & - & EMP \\
\hline & & & & & 06-15-1999 & 1258 & 676.97 & $2,379.0$ & V & - & EMP \\
\hline & & & & & 07-28-1999 & 1001 & 677.06 & $2,378.9$ & $\mathrm{~V}$ & - & EMP \\
\hline & & & & & 08-09-1999 & 0946 & 677.72 & $2,378.3$ & V & - & EMP \\
\hline & & & & & 09-24-1999 & 1507 & 677.74 & $2,378.3$ & V & - & EMP \\
\hline & & & & & 10-07-1999 & 0710 & 677.88 & $2,378.1$ & V & - & EMP \\
\hline
\end{tabular}




\begin{tabular}{|c|c|c|c|c|c|c|c|c|c|c|c|}
\hline \multirow[b]{2}{*}{$\begin{array}{c}\text { Site } \\
\text { number } \\
\text { (fig. 1) }\end{array}$} & \multirow[b]{2}{*}{$\begin{array}{l}\text { U.S. Geological } \\
\text { Survey site } \\
\text { identification }\end{array}$} & \multirow[b]{2}{*}{ Site name } & \multirow[b]{2}{*}{$\begin{array}{c}\text { Land-surface } \\
\text { altitude } \\
\text { (feet above } \\
\text { sea level) }\end{array}$} & \multirow{2}{*}{$\begin{array}{l}\text { Height of } \\
\text { measurement } \\
\text { point (feet } \\
\text { above land } \\
\text { surface) }\end{array}$} & \multicolumn{7}{|c|}{ Water-level measurement } \\
\hline & & & & & Date & Time & $\begin{array}{l}\text { Depth to water } \\
\text { (feet below } \\
\text { land } \\
\text { surface) }\end{array}$ & $\begin{array}{c}\text { Altitude of } \\
\text { water surface } \\
\text { (feet above } \\
\text { sea level) }\end{array}$ & Method & $\begin{array}{l}\text { Site } \\
\text { status }\end{array}$ & $\begin{array}{c}\text { Data } \\
\text { source }\end{array}$ \\
\hline \multirow[t]{3}{*}{$\mathrm{RV}-1$} & 363815116175901 & TW-5 & 3056.0 & 1.6 & 10-16-1999 & 1523 & 677.92 & $2,378.1$ & $\mathrm{~V}$ & - & EMP \\
\hline & & & & & 11-04-1999 & 1700 & 678.04 & $2,378.0$ & $\mathrm{~V}$ & - & EMP \\
\hline & & & & & 12-14-1999 & 1202 & 678.08 & $2,377.9$ & $\mathrm{~V}$ & - & EMP \\
\hline \multirow[t]{12}{*}{ MV-1 } & 363530116021401 & Army $1 \mathrm{WW}$ & 3153.3 & 3.10 & 01-28-1999 & 0850 & 785.33 & $2,368.0$ & $\mathrm{~V}$ & $\mathrm{Z}$ & EMP \\
\hline & & & & & 02-25-1999 & 0805 & 784.74 & $2,368.6$ & $\mathrm{~V}$ & $\mathrm{Z}$ & EMP \\
\hline & & & & & 03-25-1999 & 0827 & 784.95 & $2,368.4$ & $\mathrm{~V}$ & $\mathrm{Z}$ & EMP \\
\hline & & & & & 04-27-1999 & 1009 & 784.90 & $2,368.4$ & $\mathrm{~V}$ & $\mathrm{Z}$ & EMP \\
\hline & & & & & 05-20-1999 & 0745 & 785.09 & $2,368.2$ & $\mathrm{~V}$ & $\mathrm{Z}$ & EMP \\
\hline & & & & & 06-17-1999 & 0750 & 785.04 & $2,368.3$ & $\mathrm{~V}$ & $\mathrm{Z}$ & EMP \\
\hline & & & & & 07-28-1999 & 0902 & 785.11 & $2,368.2$ & $\mathrm{~V}$ & $\mathrm{Z}$ & EMP \\
\hline & & & & & 08-09-1999 & 0823 & 785.03 & $2,368.3$ & $\mathrm{~V}$ & $\mathrm{Z}$ & EMP \\
\hline & & & & & 09-27-1999 & 0802 & 784.97 & $2,368.3$ & $\mathrm{~V}$ & $\mathrm{Z}$ & EMP \\
\hline & & & & & 10-19-1999 & 0738 & 785.24 & $2,368.1$ & $\mathrm{~V}$ & $\mathrm{Z}$ & EMP \\
\hline & & & & & 11-04-1999 & 0735 & 784.95 & $2,368.4$ & $\mathrm{~V}$ & $\mathrm{Z}$ & EMP \\
\hline & & & & & 12-14-1999 & 0740 & 785.28 & $2,368.0$ & $\mathrm{~V}$ & $\mathrm{Z}$ & EMP \\
\hline \multirow[t]{15}{*}{$\mathrm{AD}-1$} & 364141116351401 & USGS Well NA-6 BGMW-10 & 2627.9 & 1.7 & 01-26-1999 & 1253 & 269.68 & $2,358.2$ & S & - & EMP \\
\hline & & & & & 02-16-1999 & - & 269.8 & $2,358.1$ & $\mathrm{R}$ & - & PVT \\
\hline & & & & & 02-23-1999 & 0920 & 269.62 & $2,358.3$ & $S$ & - & EMP \\
\hline & & & & & 03-24-1999 & 1205 & 269.62 & $2,358.3$ & $S$ & - & EMP \\
\hline & & & & & 04-14-1999 & 1027 & 269.75 & $2,358.2$ & $S$ & - & EMP \\
\hline & & & & & 05-18-1999 & - & 269.8 & $2,358.1$ & $\mathrm{R}$ & - & PVT \\
\hline & & & & & 05-19-1999 & 1020 & 269.35 & $2,358.6$ & S & - & EMP \\
\hline & & & & & 06-16-1999 & 1018 & 269.60 & $2,358.3$ & S & - & EMP \\
\hline & & & & & 07-27-1999 & 1929 & 269.52 & $2,358.4$ & $\mathrm{~S}$ & - & EMP \\
\hline & & & & & 08-09-1999 & 1417 & 269.53 & $2,358.4$ & S & - & EMP \\
\hline & & & & & 09-24-1999 & 1153 & 269.67 & $2,358.2$ & $S$ & - & EMP \\
\hline & & & & & 09-28-1999 & - & 269.80 & $2,358.1$ & $\mathrm{R}$ & - & PVT \\
\hline & & & & & $10-07-1999$ & 1015 & 269.88 & $2,358.0$ & S & - & EMP \\
\hline & & & & & 11-04-1999 & 1532 & 269.50 & $2,358.4$ & $\mathrm{~S}$ & - & EMP \\
\hline & & & & & 11-26-1999 & 1237 & 269.63 & $2,358.3$ & $\mathrm{~V}$ & - & USGS-NV \\
\hline \multirow{7}{*}{ 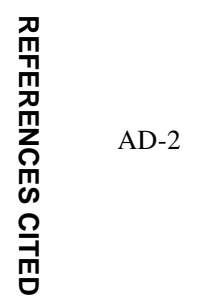 } & & & & & 12-03-1999 & - & 269.90 & $2,358.0$ & $\mathrm{R}$ & - & PVT \\
\hline & & & & & $12-13-1999$ & 1422 & 269.47 & $2,358.4$ & $\mathrm{~S}$ & - & EMP \\
\hline & 363830116241401 & Airport Well & $2,638.8$ & 1.05 & 01-28-1999 & 0940 & 325.34 & $2,313.5$ & $\mathrm{~V}$ & - & EMP \\
\hline & & & & & 02-25-1999 & 0938 & 325.01 & $2,313.8$ & $\mathrm{~V}$ & - & EMP \\
\hline & & & & & 03-24-1999 & 1322 & 325.09 & $2,313.7$ & $\mathrm{~V}$ & - & EMP \\
\hline & & & & & 04-14-1999 & 1150 & 325.26 & $2,313.5$ & $\mathrm{~V}$ & - & EMP \\
\hline & & & & & 05-19-1999 & 1210 & 325.07 & $2,313.7$ & $\mathrm{~V}$ & - & EMP \\
\hline
\end{tabular}


Table 5. Periodic water-level data at monitoring sites in Yucca Mountain region for calendar year 1999-Continued

\begin{tabular}{|c|c|c|c|c|c|c|c|c|c|c|c|}
\hline \multirow[b]{2}{*}{ 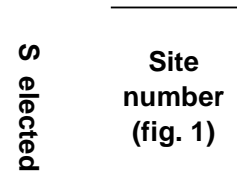 } & \multirow[b]{2}{*}{$\begin{array}{l}\text { U.S. Geological } \\
\text { Survey site } \\
\text { identification }\end{array}$} & \multirow[b]{2}{*}{ Site name } & \multirow[b]{2}{*}{$\begin{array}{c}\text { Land-surface } \\
\text { altitude } \\
\text { (feet above } \\
\text { sea level) }\end{array}$} & \multirow[b]{2}{*}{$\begin{array}{l}\text { Height of } \\
\text { measurement } \\
\text { point (feet } \\
\text { above land } \\
\text { surface) }\end{array}$} & \multicolumn{7}{|c|}{ Water-level measurement } \\
\hline & & & & & Date & Time & $\begin{array}{l}\text { Depth to water } \\
\text { (feet below } \\
\text { land } \\
\text { surface) }\end{array}$ & $\begin{array}{c}\text { Altitude of } \\
\text { water surface } \\
\text { (feet above } \\
\text { sea level) }\end{array}$ & Method & $\begin{array}{l}\text { Site } \\
\text { status }\end{array}$ & $\begin{array}{l}\text { Data } \\
\text { source }\end{array}$ \\
\hline \multirow[t]{8}{*}{ AD-2 } & \multirow[t]{8}{*}{363830116241401} & \multirow[t]{8}{*}{ Airport Well } & \multirow[t]{8}{*}{$2,638.8$} & \multirow{8}{*}{1.15} & 06-16-1999 & 1205 & 325.57 & $2,313.2$ & $\nabla$ & $\overline{-}$ & EMP \\
\hline & & & & & 07-27-1999 & 1629 & 325.16 & $2,313.6$ & $\mathrm{~S}$ & - & EMP \\
\hline & & & & & 08-09-1999 & 1038 & 325.24 & $2,313.6$ & $\mathrm{~S}$ & - & EMP \\
\hline & & & & & 09-23-1999 & 1358 & 325.17 & $2,313.6$ & $S$ & - & EMP \\
\hline & & & & & 10-07-1999 & 0753 & 325.53 & $2,313.3$ & S & - & EMP \\
\hline & & & & & $10-16-1999$ & 1332 & 325.52 & $2,313.3$ & $\mathrm{~S}$ & - & EMP \\
\hline & & & & & 11-04-1999 & 1219 & 325.25 & $2,313.6$ & S & - & EMP \\
\hline & & & & & 12-14-1999 & 0919 & 325.61 & $2,313.2$ & $S$ & - & EMP \\
\hline \multirow[t]{13}{*}{$\mathrm{AD}-2 \mathrm{a}$} & \multirow[t]{13}{*}{363835116234001} & \multirow[t]{13}{*}{ NDOT Well } & \multirow[t]{13}{*}{$2,656.8$} & \multirow[t]{13}{*}{0.4} & 01-28-1999 & 0959 & 342.47 & $2,314.3$ & V & - & EMP \\
\hline & & & & & 02-25-1999 & 1005 & 341.93 & $2,314.9$ & $\mathrm{~S}$ & - & EMP \\
\hline & & & & & 03-25-1999 & 0925 & 342.01 & $2,314.8$ & S & - & EMP \\
\hline & & & & & 04-12-1999 & 1345 & 343.72 & $2,313.1$ & S & - & EMP \\
\hline & & & & & 05-19-1999 & 1140 & 344.74 & $2,312.1$ & $\mathrm{~S}$ & - & EMP \\
\hline & & & & & 06-16-1999 & 0710 & 343.92 & $2,312.9$ & $\mathrm{~S}$ & - & EMP \\
\hline & & & & & 07-28-1999 & 0814 & 343.06 & $2,313.7$ & S & - & EMP \\
\hline & & & & & 08-26-1999 & 1448 & 342.67 & $2,314.1$ & S & - & EMP \\
\hline & & & & & 09-23-1999 & 1429 & 342.99 & $2,313.8$ & S & - & EMP \\
\hline & & & & & 10-07-1999 & 1210 & 343.39 & $2,313.4$ & $S$ & - & EMP \\
\hline & & & & & $10-18-1999$ & 1819 & 342.34 & $2,314.5$ & $\mathrm{~S}$ & - & EMP \\
\hline & & & & & 11-04-1999 & 1624 & 342.22 & $2,314.6$ & S & - & EMP \\
\hline & & & & & 12-13-1999 & 1146 & 341.92 & $2,314.9$ & S & - & EMP \\
\hline \multirow[t]{13}{*}{$\mathrm{AD}-3 \mathrm{a}$} & \multirow[t]{13}{*}{363521116352501} & \multirow[t]{13}{*}{ Davidson Well } & \multirow[t]{13}{*}{$2,395.3$} & \multirow[t]{13}{*}{1.00} & 01-27-1999 & 1155 & 132.19 & $2,263.1$ & $\mathrm{~S}$ & - & EMP \\
\hline & & & & & 02-23-1999 & 1030 & 132.10 & $2,263.2$ & $\mathrm{~S}$ & - & EMP \\
\hline & & & & & 03-16-1999 & 1320 & 132.03 & $2,263.3$ & $\mathrm{~S}$ & - & EMP \\
\hline & & & & & 04-12-1999 & 1447 & 132.08 & $2,263.2$ & $\mathrm{~S}$ & - & EMP \\
\hline & & & & & 05-19-1999 & 1315 & 132.28 & $2,263.0$ & $\mathrm{~S}$ & - & EMP \\
\hline & & & & & 06-15-1999 & 1125 & 132.42 & $2,262.9$ & $\mathrm{~S}$ & - & EMP \\
\hline & & & & & 07-27-1999 & 1525 & 132.64 & $2,262.7$ & $\mathrm{~S}$ & - & EMP \\
\hline & & & & & 08-06-1999 & 1430 & 132.73 & $2,262.6$ & S & - & EMP \\
\hline & & & & & 09-23-1999 & 1308 & 132.88 & $2,262.4$ & $\mathrm{~S}$ & - & EMP \\
\hline & & & & & 10-08-1999 & 0715 & 133.00 & $2,262.3$ & S & - & EMP \\
\hline & & & & & 10-16-1999 & 1417 & 132.99 & $2,262.3$ & $\mathrm{~S}$ & - & EMP \\
\hline & & & & & 11-15-1999 & 0624 & 133.07 & $2,262.2$ & S & - & EMP \\
\hline & & & & & 12-13-1999 & 1526 & 132.92 & $2,262.4$ & $\mathrm{~S}$ & - & EMP \\
\hline \multirow[t]{5}{*}{ AD-4a } & \multirow[t]{5}{*}{363428116234701} & Cooks East Well & $2,477.8$ & 1.0 & 01-27-1999 & 1242 & 119.79 & $2,358.0$ & S & - & EMP \\
\hline & & & & & 02-23-1999 & 1149 & 119.70 & $2,358.1$ & $\mathrm{~S}$ & - & EMP \\
\hline & & & & & 03-16-1999 & 1250 & 119.62 & $2,358.2$ & $\mathrm{~S}$ & - & EMP \\
\hline & & & & & 04-12-1999 & 1420 & 119.68 & $2,358.1$ & $\mathrm{~S}$ & - & EMP \\
\hline & & & & & 05-19-1999 & 1248 & 119.57 & $2,358.2$ & $\mathrm{~S}$ & - & EMP \\
\hline
\end{tabular}




\begin{tabular}{|c|c|c|c|c|c|c|c|c|c|c|c|}
\hline \multirow[b]{2}{*}{$\begin{array}{c}\text { Site } \\
\text { number } \\
\text { (fig. 1) }\end{array}$} & \multirow[b]{2}{*}{$\begin{array}{l}\text { U.S. Geological } \\
\text { Survey site } \\
\text { identification }\end{array}$} & \multirow[b]{2}{*}{ Site name } & \multirow[b]{2}{*}{$\begin{array}{c}\text { Land-surface } \\
\text { altitude } \\
\text { (feet above } \\
\text { sea level) }\end{array}$} & \multirow[b]{2}{*}{$\begin{array}{l}\text { Height of } \\
\text { measurement } \\
\text { point (feet } \\
\text { above land } \\
\text { surface) }\end{array}$} & \multicolumn{7}{|c|}{ Water-level measurement } \\
\hline & & & & & Date & Time & $\begin{array}{l}\text { Depth to water } \\
\text { (feet below } \\
\text { land } \\
\text { surface) }\end{array}$ & $\begin{array}{c}\text { Altitude of } \\
\text { water surface } \\
\text { (feet above } \\
\text { sea level) }\end{array}$ & Method & $\begin{array}{c}\text { Site } \\
\text { status }\end{array}$ & $\begin{array}{l}\text { Data } \\
\text { source }\end{array}$ \\
\hline \multirow[t]{8}{*}{$\mathrm{AD}-4 \mathrm{a}$} & 363428116234701 & Cooks East Well & $2,477.8$ & 1.0 & 06-15-1999 & 1210 & 119.63 & $2,358.2$ & $\mathrm{~S}$ & - & EMP \\
\hline & & & & & 07-27-1999 & 1557 & 119.58 & $2,358.2$ & $\mathrm{~S}$ & - & EMP \\
\hline & & & & & 08-06-1999 & 1500 & 119.26 & $2,358.5$ & $\mathrm{~S}$ & - & EMP \\
\hline & & & & & 09-23-1999 & 1336 & 119.40 & $2,358.4$ & $\mathrm{~S}$ & - & EMP \\
\hline & & & & & 10-08-1999 & 0648 & 119.55 & $2,358.2$ & $\mathrm{~S}$ & - & EMP \\
\hline & & & & & 10-16-1999 & 1310 & 116.56 & $2,361.2$ & $\mathrm{~S}$ & - & EMP \\
\hline & & & & & 11-04-1999 & 1159 & 116.70 & $2,361.1$ & $\mathrm{~S}$ & - & EMP \\
\hline & & & & & 12-14-1999 & 0944 & 117.38 & $2,360.4$ & $\mathrm{~S}$ & - & EMP \\
\hline \multirow[t]{13}{*}{ AD-5 } & 363310116294001 & USBLM Well & $2,376.4$ & 0.0 & 01-20-1999 & 1313 & 128.83 & $2,247.6$ & $\mathrm{~S}$ & - & EMP \\
\hline & & & & & 02-23-1999 & 1110 & 127.20 & $2,249.2$ & $\mathrm{~S}$ & - & EMP \\
\hline & & & & & 03-16-1999 & 1350 & 127.61 & $2,248.8$ & $\mathrm{~S}$ & - & EMP \\
\hline & & & & & 04-12-1999 & 1521 & 127.66 & $2,248.7$ & $\mathrm{~S}$ & - & EMP \\
\hline & & & & & 05-19-1999 & 1340 & 127.74 & $2,248.7$ & $\mathrm{~S}$ & - & EMP \\
\hline & & & & & 06-15-1999 & 1100 & 127.90 & $2,248.5$ & $\mathrm{~S}$ & - & EMP \\
\hline & & & & & 07-27-1999 & 1502 & 128.10 & $2,248.3$ & $\mathrm{~S}$ & - & EMP \\
\hline & & & & & 08-06-1999 & 1404 & 128.16 & $2,248.2$ & $\mathrm{~S}$ & - & EMP \\
\hline & & & & & 09-23-1999 & 1244 & 128.48 & $2,247.9$ & $\mathrm{~S}$ & - & EMP \\
\hline & & & & & 10-08-1999 & 0737 & 128.58 & $2,247.8$ & $\mathrm{~S}$ & - & EMP \\
\hline & & & & & 10-16-1999 & 1358 & 128.64 & $2,247.8$ & $\mathrm{~S}$ & - & EMP \\
\hline & & & & & 11-15-1999 & 0655 & 128.74 & $2,247.7$ & $\mathrm{~S}$ & - & EMP \\
\hline & & & & & 12-13-1999 & 1549 & 128.72 & $2,247.7$ & $\mathrm{~S}$ & - & EMP \\
\hline \multirow[t]{12}{*}{ AD-6 } & 363213116133800 & Tracer Well 3 & $2,402.3$ & 0.4 & 01-28-1999 & 1031 & 41.80 & $2,360.5$ & $\mathrm{~S}$ & - & EMP \\
\hline & & & & & 02-03-1999 & 1132 & 41.62 & $2,360.7$ & $\mathrm{~S}$ & - & EMP \\
\hline & & & & & 03-03-1999 & 1031 & 41.52 & $2,360.8$ & S & - & EMP \\
\hline & & & & & 04-06-1999 & 1330 & 41.65 & $2,360.6$ & $\mathrm{~S}$ & - & EMP \\
\hline & & & & & 05-03-1999 & 0846 & 41.50 & $2,360.8$ & $\mathrm{~S}$ & - & EMP \\
\hline & & & & & 06-01-1999 & 0930 & 41.58 & $2,360.7$ & $\mathrm{~S}$ & - & EMP \\
\hline & & & & & 07-07-1999 & 0745 & 41.65 & $2,360.6$ & $\mathrm{~S}$ & - & EMP \\
\hline & & & & & 08-03-1999 & 0746 & 41.66 & $2,360.6$ & $\mathrm{~S}$ & - & EMP \\
\hline & & & & & 09-01-1999 & 0816 & 41.55 & $2,360.8$ & $\mathrm{~S}$ & - & EMP \\
\hline & & & & & 10-05-1999 & 0800 & 41.60 & $2,360.7$ & $\mathrm{~S}$ & - & EMP \\
\hline & & & & & 11-01-1999 & 0846 & 41.77 & $2,360.5$ & $\mathrm{~S}$ & - & EMP \\
\hline & & & & & 12-14-1999 & 1115 & 41.82 & $2,360.5$ & $\mathrm{~S}$ & - & EMP \\
\hline \multirow[t]{5}{*}{ AD-7a } & 363009116302702 & BlackmanWell & $2,305.0$ & 0.78 & 01-27-1999 & 1120 & 69.60 & $2,235.4$ & $\mathrm{~S}$ & - & EMP \\
\hline & & & & & 02-23-1999 & 1230 & 69.55 & $2,235.4$ & $\mathrm{~S}$ & - & EMP \\
\hline & & & & & 03-11-1999 & - & 69.89 & $2,235.1$ & $\mathrm{~T}$ & - & NDWR \\
\hline & & & & & 03-16-1999 & 1415 & 70.54 & $2,234.5$ & $\mathrm{~S}$ & - & EMP \\
\hline & & & & & 04-12-1999 & 1546 & 71.36 & $2,233.6$ & $\mathrm{~S}$ & - & EMP \\
\hline
\end{tabular}


Table 5. Periodic water-level data at monitoring sites in Yucca Mountain region for calendar year 1999—Continued

\begin{tabular}{|c|c|c|c|c|c|c|c|c|c|c|c|}
\hline \multirow[b]{2}{*}{$\begin{array}{c}\text { Site } \\
\text { number } \\
\text { (fig. 1) }\end{array}$} & \multirow[b]{2}{*}{$\begin{array}{l}\text { U.S. Geological } \\
\text { Survey site } \\
\text { identification }\end{array}$} & \multirow[b]{2}{*}{ Site name } & \multirow[b]{2}{*}{$\begin{array}{l}\text { Land-surface } \\
\text { altitude } \\
\text { (feet above } \\
\text { sea level) }\end{array}$} & \multirow{2}{*}{$\begin{array}{l}\text { Height of } \\
\text { measurement } \\
\text { point (feet } \\
\text { above land } \\
\text { surface) }\end{array}$} & \multicolumn{7}{|c|}{ Water-level measurement } \\
\hline & & & & & Date & Time & $\begin{array}{l}\text { Depth to water } \\
\text { (feet below } \\
\text { land } \\
\text { surface) }\end{array}$ & $\begin{array}{c}\text { Altitude of } \\
\text { water surface } \\
\text { (feet above } \\
\text { sea level) }\end{array}$ & Method & $\begin{array}{c}\text { Site } \\
\text { status }\end{array}$ & $\begin{array}{l}\text { Data } \\
\text { source }\end{array}$ \\
\hline \multirow[t]{10}{*}{$\mathrm{AD}-7 \mathrm{a}$} & 363009116302702 & BlackmanWell & $2,305.0$ & 0.78 & 05-19-1999 & 1355 & 73.76 & $2,231.2$ & $\mathrm{~S}$ & - & EMP \\
\hline & & & & & 06-15-1999 & 1040 & 74.94 & $2,230.1$ & $\mathrm{~S}$ & - & EMP \\
\hline & & & & & 07-27-1999 & 1445 & 76.46 & $2,228.5$ & S & - & EMP \\
\hline & & & & & 08-06-1999 & 1340 & 77.02 & $2,228.0$ & S & - & EMP \\
\hline & & & & & 09-23-1999 & 1223 & 77.19 & $2,227.8$ & $\mathrm{~S}$ & - & EMP \\
\hline & & & & & 10-08-1999 & 0753 & 77.19 & $2,227.8$ & $\mathrm{~S}$ & - & EMP \\
\hline & & & & & 10-09-1999 & - & 77.08 & $2,227.9$ & $\mathrm{~S}$ & - & NDWR \\
\hline & & & & & 10-19-1999 & 1319 & 77.00 & $2,228.0$ & $\mathrm{~S}$ & - & EMP \\
\hline & & & & & 11-15-1999 & 0713 & 75.94 & $2,229.1$ & S & - & EMP \\
\hline & & & & & 12-13-1999 & 1610 & 74.72 & $2,230.3$ & $\mathrm{~S}$ & - & EMP \\
\hline \multirow{13}{*}{ AD-8 } & 362929116085701 & Cherry Patch Well & $2,394.3$ & 0.6 & 01-28-1999 & 0715 & 35.15 & $2,359.2$ & $\mathrm{~S}$ & - & EMP \\
\hline & & & & & 02-25-1999 & 0705 & 35.19 & $2,359.1$ & S & - & EMP \\
\hline & & & & & 03-25-1999 & 0712 & 35.00 & $2,359.3$ & $\mathrm{~S}$ & - & EMP \\
\hline & & & & & 04-27-1999 & 0932 & 35.00 & $2,359.3$ & $\mathrm{~S}$ & - & EMP \\
\hline & & & & & 05-20-1999 & 0820 & 42.44 & $2,351.9$ & S & $\mathrm{P}$ & EMP \\
\hline & & & & & 06-17-1999 & 0720 & 49.13 & $2,345.2$ & $\mathrm{~S}$ & $\mathrm{P}$ & EMP \\
\hline & & & & & 07-28-1999 & 1215 & 51.49 & $2,342.8$ & S & $\mathrm{P}$ & EMP \\
\hline & & & & & 08-26-1999 & 1647 & 34.44 & $2,359.9$ & $\mathrm{~S}$ & - & EMP \\
\hline & & & & & 09-29-1999 & 0857 & 34.95 & $2,359.4$ & $\mathrm{~S}$ & - & EMP \\
\hline & & & & & 10-07-1999 & 1425 & 35.03 & $2,359.3$ & $\mathrm{~S}$ & - & EMP \\
\hline & & & & & 10-19-1999 & 0848 & 35.37 & $2,358.9$ & $\mathrm{~S}$ & - & EMP \\
\hline & & & & & 11-04-1999 & 0841 & 34.45 & $2,359.8$ & S & - & EMP \\
\hline & & & & & 12-14-1999 & 1038 & 34.93 & $2,359.4$ & S & - & EMP \\
\hline \multirow[t]{15}{*}{ AD-9 } & 362848116264201 & Gilgans North Well & $2,264.8$ & -0.10 & 01-27-1999 & 1050 & 80.06 & $2,184.7$ & S & - & EMP \\
\hline & & & & & 02-23-1999 & 1250 & 80.81 & $2,184.0$ & S & - & EMP \\
\hline & & & & & 03-11-1999 & - & 81.87 & $2,182.9$ & $\mathrm{~T}$ & - & NDWR \\
\hline & & & & & 03-16-1999 & 1438 & 83.42 & $2,181.4$ & S & - & EMP \\
\hline & & & & & 04-12-1999 & 1612 & 80.94 & $2,183.9$ & $\mathrm{~S}$ & - & EMP \\
\hline & & & & & 05-19-1999 & 1415 & 86.98 & $2,177.8$ & $\mathrm{~S}$ & - & EMP \\
\hline & & & & & 06-15-1999 & 1020 & 87.92 & $2,176.9$ & $\mathrm{~S}$ & - & EMP \\
\hline & & & & & 07-27-1999 & 1429 & 89.77 & $2,175.0$ & $\mathrm{~S}$ & - & EMP \\
\hline & & & & & 08-06-1999 & 1311 & 90.17 & $2,174.6$ & $\mathrm{~S}$ & - & EMP \\
\hline & & & & & 09-23-1999 & 1202 & 84.28 & $2,180.5$ & $\mathrm{~S}$ & - & EMP \\
\hline & & & & & $10-08-1999$ & 0811 & 86.85 & $2,178.0$ & $\mathrm{~S}$ & - & EMP \\
\hline & & & & & $10-09-1999$ & - & 88.82 & $2,176.0$ & $\mathrm{~S}$ & - & NDWR \\
\hline & & & & & $10-19-1999$ & 1301 & 86.99 & $2,177.8$ & $\mathrm{~S}$ & - & EMP \\
\hline & & & & & $11-15-1999$ & 0734 & 83.82 & $2,181.0$ & $\mathrm{~S}$ & - & EMP \\
\hline & & & & & 12-13-1999 & 1641 & 82.99 & $2,181.8$ & $\mathrm{~S}$ & - & EMP \\
\hline
\end{tabular}




\begin{tabular}{|c|c|c|c|c|c|c|c|c|c|c|c|}
\hline \multirow[b]{2}{*}{$\begin{array}{c}\text { Site } \\
\text { number } \\
\text { (fig. 1) }\end{array}$} & \multirow[b]{2}{*}{$\begin{array}{l}\text { U.S. Geological } \\
\text { Survey site } \\
\text { identification }\end{array}$} & \multirow[b]{2}{*}{ Site name } & \multirow[b]{2}{*}{$\begin{array}{c}\text { Land-surface } \\
\text { altitude } \\
\text { (feet above } \\
\text { sea level) }\end{array}$} & \multirow[b]{2}{*}{$\begin{array}{c}\text { Height of } \\
\text { measurement } \\
\text { point (feet } \\
\text { above land } \\
\text { surface) }\end{array}$} & \multicolumn{7}{|c|}{ Water-level measurement } \\
\hline & & & & & Date & Time & $\begin{array}{l}\text { Depth to water } \\
\text { (feet below } \\
\text { land } \\
\text { surface) }\end{array}$ & $\begin{array}{c}\text { Altitude of } \\
\text { water surface } \\
\text { (feet above } \\
\text { sea level) }\end{array}$ & Method & $\begin{array}{c}\text { Site } \\
\text { status }\end{array}$ & $\begin{array}{c}\text { Data } \\
\text { source }\end{array}$ \\
\hline \multirow[t]{13}{*}{$\mathrm{AD}-10$} & 362525116274301 & NA-9 Well & $2,190.9$ & 1.3 & 01-27-1999 & 0635 & 12.13 & $2,178.8$ & $\mathrm{~S}$ & - & EMP \\
\hline & & & & & 02-22-1999 & 1450 & 12.18 & $2,178.7$ & $\mathrm{~S}$ & - & EMP \\
\hline & & & & & 03-16-1999 & 0922 & 12.13 & $2,178.8$ & $\mathrm{~S}$ & - & EMP \\
\hline & & & & & 04-13-1999 & 1247 & 12.19 & $2,178.7$ & $\mathrm{~S}$ & - & EMP \\
\hline & & & & & 05-18-1999 & 1333 & 12.16 & $2,178.7$ & $\mathrm{~S}$ & - & EMP \\
\hline & & & & & 06-14-1999 & 1555 & 12.20 & $2,178.7$ & $\mathrm{~S}$ & - & EMP \\
\hline & & & & & 07-27-1999 & 1403 & 12.30 & $2,178.6$ & $\mathrm{~S}$ & - & EMP \\
\hline & & & & & 08-06-1999 & 1243 & 12.18 & $2,178.7$ & $\mathrm{~S}$ & - & EMP \\
\hline & & & & & 09-17-1999 & 1306 & 12.07 & $2,178.8$ & $\mathrm{~S}$ & - & EMP \\
\hline & & & & & 10-08-1999 & 0831 & 12.12 & $2,178.8$ & $\mathrm{~S}$ & - & EMP \\
\hline & & & & & 10-19-1999 & 0926 & 12.33 & $2,178.6$ & $\mathrm{~S}$ & - & EMP \\
\hline & & & & & 11-15-1999 & 0756 & 11.40 & $2,179.5$ & $\mathrm{~S}$ & - & EMP \\
\hline & & & & & 12-14-1999 & 1004 & 11.39 & $2,179.5$ & $\mathrm{~S}$ & - & EMP \\
\hline \multirow[t]{13}{*}{$\mathrm{AD}-11$} & 361954116181201 & GS-03 Well & $2,351.3$ & 2.0 & 01-26-1999 & 0915 & 218.19 & $2,133.1$ & $\mathrm{~S}$ & - & EMP \\
\hline & & & & & 02-16-1999 & 1352 & 218.15 & $2,133.2$ & $\mathrm{~S}$ & - & EMP \\
\hline & & & & & 03-24-1999 & 0738 & 217.69 & $2,133.6$ & $\mathrm{~S}$ & - & EMP \\
\hline & & & & & 04-13-1999 & 0714 & 217.43 & $2,133.9$ & $\mathrm{~S}$ & - & EMP \\
\hline & & & & & 05-17-1999 & 1530 & 216.84 & $2,134.5$ & $\mathrm{~S}$ & - & EMP \\
\hline & & & & & 06-14-1999 & 1202 & 216.31 & $2,135.0$ & $\mathrm{~S}$ & - & EMP \\
\hline & & & & & 07-27-1999 & 1219 & 215.64 & $2,135.7$ & $\mathrm{~S}$ & - & EMP \\
\hline & & & & & 08-06-1999 & 1007 & 215.39 & $2,135.9$ & $\mathrm{~S}$ & - & EMP \\
\hline & & & & & 09-29-1999 & 1137 & 214.93 & $2,136.4$ & $\mathrm{~S}$ & - & EMP \\
\hline & & & & & 10-08-1999 & 1143 & 214.89 & $2,136.4$ & $\mathrm{~S}$ & - & EMP \\
\hline & & & & & 10-18-1999 & 1720 & 214.77 & $2,136.5$ & $\mathrm{~S}$ & - & EMP \\
\hline & & & & & 11-03-1999 & 1152 & 214.55 & $2,136.8$ & $\mathrm{~S}$ & - & EMP \\
\hline & & & & & $12-10-1999$ & 0911 & 213.77 & $2,137.5$ & $\mathrm{~S}$ & - & EMP \\
\hline \multirow[t]{13}{*}{ AD-12 } & 362014116133901 & GS-01 Well & $2,430.3$ & 2.0 & 01-26-1999 & 0840 & 80.90 & $2,349.4$ & $\mathrm{~S}$ & - & EMP \\
\hline & & & & & 02-16-1999 & 1436 & 80.88 & $2,349.4$ & $\mathrm{~S}$ & - & EMP \\
\hline & & & & & 03-24-1999 & 0650 & 80.88 & $2,349.4$ & $\mathrm{~S}$ & - & EMP \\
\hline & & & & & 04-13-1999 & 0625 & 80.86 & $2,349.4$ & $\mathrm{~S}$ & - & EMP \\
\hline & & & & & 05-19-1999 & 1508 & 80.87 & $2,349.4$ & $\mathrm{~S}$ & - & EMP \\
\hline & & & & & 06-14-1999 & 1110 & 80.88 & $2,349.4$ & $\mathrm{~S}$ & - & EMP \\
\hline & & & & & 07-27-1999 & 1139 & 80.89 & $2,349.4$ & $\mathrm{~S}$ & - & EMP \\
\hline & & & & & 08-06-1999 & 1049 & 80.94 & $2,349.4$ & $\mathrm{~S}$ & - & EMP \\
\hline & & & & & 09-17-1999 & 1021 & 80.98 & $2,349.3$ & $\mathrm{~S}$ & - & EMP \\
\hline & & & & & 10-07-1999 & 1808 & 80.97 & $2,349.3$ & $\mathrm{~S}$ & - & EMP \\
\hline & & & & & 10-16-1999 & 1105 & 81.04 & $2,349.3$ & $\mathrm{~S}$ & - & EMP \\
\hline & & & & & 11-04-1999 & 0543 & 80.98 & $2,349.3$ & $\mathrm{~S}$ & - & EMP \\
\hline & & & & & 12-10-1999 & 0832 & 80.97 & $2,349.3$ & $\mathrm{~S}$ & - & EMP \\
\hline
\end{tabular}


Table 5. Periodic water-level data at monitoring sites in Yucca Mountain region for calendar year 1999—Continued

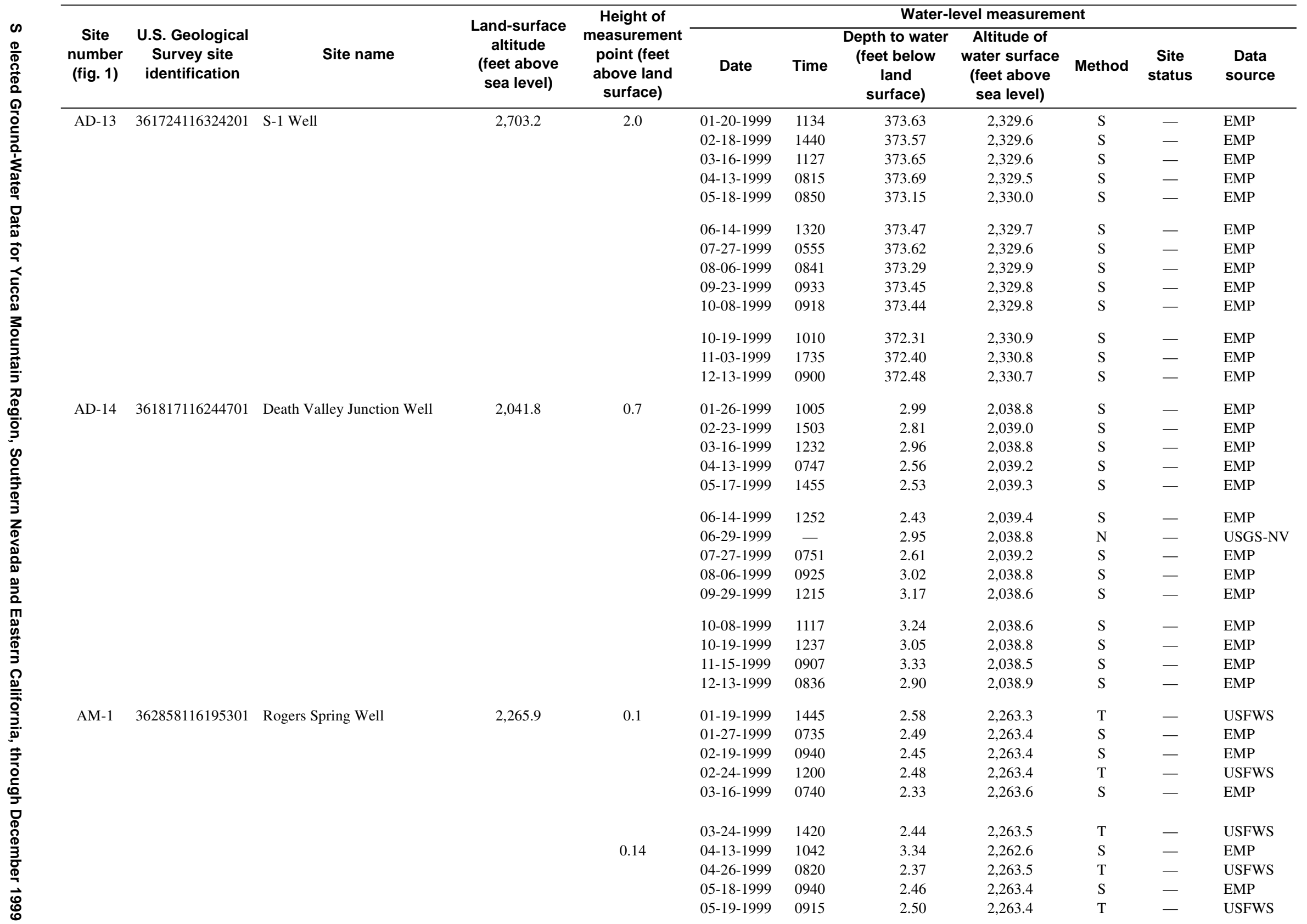




\begin{tabular}{|c|c|c|c|c|c|c|c|c|c|c|c|}
\hline \multirow[b]{2}{*}{$\begin{array}{c}\text { Site } \\
\text { number } \\
\text { (fig. 1) }\end{array}$} & \multirow[b]{2}{*}{$\begin{array}{l}\text { U.S. Geological } \\
\text { Survey site } \\
\text { identification }\end{array}$} & \multirow[b]{2}{*}{ Site name } & \multirow[b]{2}{*}{$\begin{array}{l}\text { Land-surface } \\
\text { altitude } \\
\text { (feet above } \\
\text { sea level) }\end{array}$} & \multirow{2}{*}{$\begin{array}{c}\text { Height of } \\
\text { measurement } \\
\text { point (feet } \\
\text { above land } \\
\text { surface) }\end{array}$} & \multicolumn{7}{|c|}{ Water-level measurement } \\
\hline & & & & & Date & Time & $\begin{array}{l}\text { Depth to water } \\
\text { (feet below } \\
\text { land } \\
\text { surface) }\end{array}$ & $\begin{array}{c}\text { Altitude of } \\
\text { water surface } \\
\text { (feet above } \\
\text { sea level) }\end{array}$ & Method & $\begin{array}{l}\text { Site } \\
\text { status }\end{array}$ & $\begin{array}{l}\text { Data } \\
\text { source }\end{array}$ \\
\hline \multirow[t]{20}{*}{ AM-1 } & 362858116195301 & Rogers Spring Well & $2,265.9$ & & 06-15-1999 & 0818 & 2.84 & $2,263.1$ & S & - & EMP \\
\hline & & & & & 06-21-1999 & 1010 & 3.05 & $2,262.8$ & $\mathrm{~T}$ & - & USFWS \\
\hline & & & & & 07-13-1999 & 1455 & 3.41 & $2,262.5$ & $\mathrm{~T}$ & - & USFWS \\
\hline & & & & & 07-27-1999 & 0950 & 3.55 & $2,262.4$ & S & - & EMP \\
\hline & & & & & 08-06-1999 & 1151 & 3.63 & $2,262.3$ & S & - & EMP \\
\hline & & & & & 08-19-1999 & 1050 & 3.83 & $2,262.1$ & $\mathrm{~T}$ & - & USFWS \\
\hline & & & & & 09-29-1999 & 1052 & 3.58 & $2,262.3$ & S & - & EMP \\
\hline & & & & & 09-29-1999 & 1130 & 3.33 & $2,262.6$ & $\mathrm{~T}$ & - & USFWS \\
\hline & & & & & 10-07-1999 & 1455 & 3.50 & $2,262.4$ & S & - & EMP \\
\hline & & & & & 10-16-1999 & 1240 & 3.46 & $2,262.4$ & S & - & EMP \\
\hline & & & & & 10-26-1999 & 1035 & 3.50 & $2,262.4$ & $\mathrm{~T}$ & - & USFWS \\
\hline & & & & & 11-04-1999 & 1132 & 3.15 & $2,262.8$ & S & - & EMP \\
\hline & & & & & 11-16-1999 & 1120 & 3.15 & $2,262.8$ & $\mathrm{~T}$ & - & USFWS \\
\hline & & & & & 12-10-1999 & 1210 & 2.80 & $2,263.1$ & S & - & EMP \\
\hline & & & & & $12-20-1999$ & 1445 & 2.76 & $2,263.1$ & $\mathrm{~T}$ & - & USFWS \\
\hline & & & & & $10-26-1999$ & 1035 & 3.50 & $2,262.4$ & $\mathrm{~T}$ & - & USFWS \\
\hline & & & & & 11-04-1999 & 1132 & 3.15 & $2,262.8$ & S & - & EMP \\
\hline & & & & & 11-16-1999 & 1120 & 3.15 & $2,262.8$ & $\mathrm{~T}$ & - & USFWS \\
\hline & & & & & $12-10-1999$ & 1210 & 2.80 & $2,263.1$ & S & - & EMP \\
\hline & & & & & 12-20-1999 & 1445 & 2.76 & $2,263.1$ & $\mathrm{~T}$ & - & USFWS \\
\hline \multirow[t]{13}{*}{ AM-2 } & 362755116190401 & Five Springs Well & $2,367.4$ & 1.17 & 01-27-1999 & 0805 & 0.24 & $2,367.2$ & S & $\mathrm{F}$ & EMP \\
\hline & & & & & 02-19-1999 & 0843 & 0.24 & $2,367.2$ & S & $\mathrm{F}$ & EMP \\
\hline & & & & & 03-24-1999 & 0841 & 0.23 & $2,367.2$ & S & $\mathrm{F}$ & EMP \\
\hline & & & & & 04-13-1999 & 1111 & 0.23 & $2,367.2$ & S & $\mathrm{F}$ & EMP \\
\hline & & & & & 05-18-1999 & 1000 & 0.22 & $2,367.2$ & S & $\mathrm{F}$ & EMP \\
\hline & & & & & 06-15-1999 & 0715 & 0.23 & $2,367.2$ & S & $\mathrm{F}$ & EMP \\
\hline & & & & & 07-27-1999 & 0927 & 0.24 & $2,367.2$ & S & F & EMP \\
\hline & & & & & 08-25-1999 & 1847 & 0.23 & $2,367.2$ & $\mathrm{~S}$ & $\mathrm{~F}$ & EMP \\
\hline & & & & & 09-29-1999 & 1022 & 0.23 & $2,367.2$ & S & F & EMP \\
\hline & & & & & 10-07-1999 & 1547 & 0.23 & $2,367.2$ & S & F & EMP \\
\hline & & & & & 10-18-1999 & 1602 & 0.21 & $2,367.2$ & S & $\mathrm{F}$ & EMP \\
\hline & & & & & 11-04-1999 & 1109 & 0.21 & $2,367.2$ & $S$ & $\mathrm{~F}$ & EMP \\
\hline & & & & & $12-10-1999$ & 1145 & 0.22 & $2,367.2$ & S & $\mathrm{F}$ & EMP \\
\hline \multirow[t]{5}{*}{ AM-3 } & 362555116205301 & Garners Well & $2,157.0$ & 1.29 & 01-27-1999 & 0905 & 18.72 & $2,138.3$ & S & - & EMP \\
\hline & & & & & 02-19-1999 & 1015 & 18.56 & $2,138.4$ & S & - & EMP \\
\hline & & & & & 03-16-1999 & 0708 & 18.39 & $2,138.6$ & S & - & EMP \\
\hline & & & & & 04-13-1999 & 1217 & 18.29 & $2,138.7$ & S & - & EMP \\
\hline & & & & & 05-18-1999 & 1115 & 18.24 & $2,138.8$ & S & - & EMP \\
\hline
\end{tabular}


Table 5. Periodic water-level data at monitoring sites in Yucca Mountain region for calendar year 1999—Continued

\begin{tabular}{|c|c|c|c|c|c|c|c|c|c|c|c|}
\hline \multirow[b]{2}{*}{$\begin{array}{c}\text { Site } \\
\text { number } \\
\text { (fig. 1) }\end{array}$} & \multirow[b]{2}{*}{$\begin{array}{l}\text { U.S. Geological } \\
\text { Survey site } \\
\text { identification }\end{array}$} & \multirow[b]{2}{*}{ Site name } & \multirow[b]{2}{*}{$\begin{array}{c}\text { Land-surface } \\
\text { altitude } \\
\text { (feet above } \\
\text { sea level) }\end{array}$} & \multirow[b]{2}{*}{$\begin{array}{l}\text { Height of } \\
\text { measurement } \\
\text { point (feet } \\
\text { above land } \\
\text { surface) }\end{array}$} & \multicolumn{7}{|c|}{ Water-level measurement } \\
\hline & & & & & Date & Time & $\begin{array}{l}\text { Depth to water } \\
\text { (feet below } \\
\text { land } \\
\text { surface) }\end{array}$ & $\begin{array}{c}\text { Altitude of } \\
\text { water surface } \\
\text { (feet above } \\
\text { sea level) }\end{array}$ & Method & $\begin{array}{l}\text { Site } \\
\text { status }\end{array}$ & $\begin{array}{l}\text { Data } \\
\text { source }\end{array}$ \\
\hline \multirow[t]{8}{*}{ AM-3 } & 362555116205301 & Garners Well & $2,157.0$ & 1.29 & 06-15-1999 & 0835 & 18.44 & $2,138.6$ & $\mathrm{~S}$ & - & EMP \\
\hline & & & & & 07-27-1999 & 1324 & 19.25 & $2,137.8$ & $\mathrm{~S}$ & - & EMP \\
\hline & & & & & 08-06-1999 & 1218 & 19.41 & $2,137.6$ & $\mathrm{~S}$ & - & EMP \\
\hline & & & & & 09-17-1999 & 1241 & 20.11 & $2,136.9$ & $\mathrm{~S}$ & - & EMP \\
\hline & & & & & 10-07-1999 & 1618 & 20.28 & $2,136.7$ & $\mathrm{~S}$ & - & EMP \\
\hline & & & & & $10-16-1999$ & 1226 & 20.20 & $2,136.8$ & $\mathrm{~S}$ & - & EMP \\
\hline & & & & & 11-04-1999 & 0610 & 20.11 & $2,136.9$ & $\mathrm{~S}$ & - & EMP \\
\hline & & & & & $12-10-1999$ & 1232 & 19.94 & $2,137.1$ & $\mathrm{~S}$ & - & EMP \\
\hline \multirow[t]{17}{*}{ AM-4 } & 362532116172700 & Devils Hole & $2,359.9$ & - & 01-05-1999 & 0713 & 2.01 & $2,357.9$ & $\mathrm{~S}$ & - & NPS \\
\hline & & & & & 02-04-1999 & 0733 & 1.87 & $2,358.0$ & $\mathrm{~S}$ & - & NPS \\
\hline & & & & & 03-02-1999 & 0742 & 1.95 & $2,358.0$ & $\mathrm{~S}$ & - & NPS \\
\hline & & & & & 04-06-1999 & 0553 & 1.93 & $2,358.0$ & $\mathrm{~S}$ & - & NPS \\
\hline & & & & & 04-11-1999 & 0915 & 1.98 & $2,357.9$ & $\mathrm{~S}$ & - & NPS \\
\hline & & & & & 05-04-1999 & 0548 & 1.93 & $2,358.0$ & $\mathrm{~S}$ & - & NPS \\
\hline & & & & & 05-19-1999 & 0538 & 1.88 & $2,358.0$ & $\mathrm{~S}$ & - & NPS \\
\hline & & & & & 06-01-1999 & 0535 & 1.89 & $2,358.0$ & $\mathrm{~S}$ & - & NPS \\
\hline & & & & & 06-16-1999 & 0543 & 1.88 & $2,358.0$ & $\mathrm{~S}$ & - & NPS \\
\hline & & & & & 07-06-1999 & 0730 & 2.02 & $2,357.9$ & $\mathrm{~S}$ & - & NPS \\
\hline & & & & & 08-03-1999 & 0618 & 2.01 & $2,357.9$ & $\mathrm{~S}$ & - & NPS \\
\hline & & & & & 08-18-1999 & 1112 & 1.89 & $2,358.0$ & $\mathrm{~S}$ & - & EMP \\
\hline & & & & & 09-01-1999 & 0559 & 1.90 & $2,358.0$ & $\mathrm{~S}$ & - & NPS \\
\hline & & & & & 10-01-1999 & 0732 & 1.89 & $2,358.0$ & $\mathrm{~S}$ & - & NPS \\
\hline & & & & & 10-19-1999 & 0631 & 2.22 & $2,357.7$ & $\mathrm{~S}$ & - & NPS \\
\hline & & & & & 11-02-1999 & 0723 & 2.22 & $2,357.7$ & $\mathrm{~S}$ & - & NPS \\
\hline & & & & & 12-01-1999 & 0714 & 2.11 & $2,357.8$ & $\mathrm{~S}$ & - & NPS \\
\hline \multirow[t]{10}{*}{ AM-5 } & 362529116171100 & Devils Hole Well & $2,404.1$ & 0.9 & 01-19-1999 & 1610 & 48.10 & $2,356.0$ & $\mathrm{~T}$ & - & USFWS \\
\hline & & & & & 01-27-1999 & 0930 & 48.17 & $2,355.9$ & $\mathrm{~S}$ & - & EMP \\
\hline & & & & & 02-18-1999 & 1025 & 48.10 & $2,356.0$ & $S$ & - & EMP \\
\hline & & & & & 02-24-1999 & 1000 & 48.13 & $2,356.0$ & $\mathrm{~T}$ & - & USFWS \\
\hline & & & & & 03-16-1999 & 0637 & 48.05 & $2,356.0$ & $\mathrm{~S}$ & - & EMP \\
\hline & & & & & 03-24-1999 & 1115 & 48.10 & $2,356.0$ & $\mathrm{~T}$ & - & USFWS \\
\hline & & & & & 04-13-1999 & 1325 & 48.14 & $2,356.0$ & $\mathrm{~S}$ & - & EMP \\
\hline & & & & & 04-26-1999 & 1015 & 48.14 & $2,356.0$ & $\mathrm{~T}$ & - & USFWS \\
\hline & & & & & 05-18-1999 & 1130 & 48.09 & $2,356.0$ & $\mathrm{~S}$ & - & EMP \\
\hline & & & & & 05-19-1999 & 1100 & 48.08 & $2,356.0$ & $\mathrm{~T}$ & - & USFWS \\
\hline
\end{tabular}




\begin{tabular}{|c|c|c|c|c|c|c|c|c|c|c|c|}
\hline \multirow[b]{2}{*}{$\begin{array}{c}\text { Site } \\
\text { number } \\
\text { (fig. 1) }\end{array}$} & \multirow[b]{2}{*}{$\begin{array}{l}\text { U.S. Geological } \\
\text { Survey site } \\
\text { identification }\end{array}$} & \multirow[b]{2}{*}{ Site name } & \multirow[b]{2}{*}{$\begin{array}{c}\text { Land-surface } \\
\text { altitude } \\
\text { (feet above } \\
\text { sea level) }\end{array}$} & \multirow[b]{2}{*}{$\begin{array}{l}\text { Height of } \\
\text { measurement } \\
\text { point (feet } \\
\text { above land } \\
\text { surface) }\end{array}$} & \multicolumn{7}{|c|}{ Water-level measurement } \\
\hline & & & & & Date & Time & $\begin{array}{l}\text { Depth to water } \\
\text { (feet below } \\
\text { land } \\
\text { surface) }\end{array}$ & $\begin{array}{c}\text { Altitude of } \\
\text { water surface } \\
\text { (feet above } \\
\text { sea level) }\end{array}$ & Method & $\begin{array}{l}\text { Site } \\
\text { status }\end{array}$ & $\begin{array}{l}\text { Data } \\
\text { source }\end{array}$ \\
\hline \multirow[t]{15}{*}{ AM-5 } & 362529116171100 & Devils Hole Well & $2,404.1$ & 0.9 & 06-15-1999 & 0853 & 48.06 & $2,356.0$ & $\mathrm{~S}$ & - & EMP \\
\hline & & & & & 06-21-1999 & 1110 & 48.05 & $2,356.0$ & $\mathrm{~T}$ & - & USFWS \\
\hline & & & & & 07-13-1999 & 1535 & 48.12 & $2,356.0$ & $\mathrm{~T}$ & - & USFWS \\
\hline & & & & & 07-27-1999 & 1305 & 48.15 & $2,356.0$ & S & - & EMP \\
\hline & & & & & 08-06-1999 & 1122 & 48.04 & $2,356.1$ & S & - & EMP \\
\hline & & & & & 08-19-1999 & 1155 & 48.01 & $2,356.1$ & $\mathrm{~T}$ & - & USFWS \\
\hline & & & & & 09-17-1999 & 1227 & 47.96 & $2,356.1$ & S & - & EMP \\
\hline & & & & & 09-29-1999 & 0915 & 48.04 & $2,356.1$ & $\mathrm{~T}$ & - & USFWS \\
\hline & & & & & $10-07-1999$ & 1634 & 47.95 & $2,356.2$ & S & - & EMP \\
\hline & & & & & 10-16-1999 & 1211 & 48.01 & $2,356.1$ & $S$ & - & EMP \\
\hline & & & & & $10-26-1999$ & 0920 & 48.01 & $2,356.1$ & $\mathrm{~T}$ & - & USFWS \\
\hline & & & & & 11-04-1999 & 0621 & 47.98 & $2,356.1$ & S & - & EMP \\
\hline & & & & & 11-16-1999 & 1025 & 47.97 & $2,356.1$ & $\mathrm{~T}$ & - & USFWS \\
\hline & & & & & $12-10-1999$ & 1038 & 47.93 & $2,356.2$ & S & - & EMP \\
\hline & & & & & $12-20-1999$ & 1545 & 47.97 & $2,356.1$ & $\mathrm{~T}$ & - & USFWS \\
\hline \multirow[t]{25}{*}{ AM-6 } & 362432116165701 & Point of Rocks North Well & $2,318.8$ & 0.0 & 01-19-1999 & 1655 & 21.41 & $2,297.4$ & $\mathrm{~T}$ & - & USFWS \\
\hline & & & & & 01-27-1999 & 0948 & 21.45 & $2,297.4$ & S & - & EMP \\
\hline & & & & & 02-19-1999 & 0705 & 21.47 & $2,297.3$ & S & - & EMP \\
\hline & & & & & 02-24-1999 & 1033 & 21.45 & $2,297.4$ & $\mathrm{~T}$ & - & USFWS \\
\hline & & & & & 03-16-1999 & 0816 & 21.53 & $2,297.3$ & S & - & EMP \\
\hline & & & & & 03-24-1999 & 1043 & 21.53 & $2,297.3$ & $\mathrm{~T}$ & - & USFWS \\
\hline & & & & & 04-13-1999 & 1352 & 21.54 & $2,297.3$ & S & - & EMP \\
\hline & & & & & 04-26-1999 & 1027 & 21.50 & $2,297.3$ & $\mathrm{~T}$ & - & USFWS \\
\hline & & & & & 05-18-1999 & 1218 & 21.56 & $2,297.2$ & $S$ & - & EMP \\
\hline & & & & & 05-19-1999 & 1136 & 21.51 & $2,297.3$ & $\mathrm{~T}$ & - & USFWS \\
\hline & & & & & 06-15-1999 & 0922 & 21.55 & $2,297.2$ & $\mathrm{~S}$ & - & EMP \\
\hline & & & & & 06-21-1999 & 1147 & 21.54 & $2,297.3$ & $\mathrm{~T}$ & - & USFWS \\
\hline & & & & & 07-13-1999 & 1600 & 21.56 & $2,297.2$ & $\mathrm{~T}$ & - & USFWS \\
\hline & & & & & 07-27-1999 & 1030 & 21.70 & $2,297.1$ & $S$ & - & EMP \\
\hline & & & & & 08-05-1999 & 1929 & 21.64 & $2,297.2$ & S & - & EMP \\
\hline & & & & & 08-19-1999 & 1020 & 21.61 & $2,297.2$ & $\mathrm{~T}$ & - & USFWS \\
\hline & & & & & 09-17-1999 & 1101 & 21.61 & $2,297.2$ & $S$ & - & EMP \\
\hline & & & & & 09-29-1999 & 0900 & 21.56 & $2,297.2$ & $\mathrm{~T}$ & - & USFWS \\
\hline & & & & & $10-07-1999$ & 1706 & 21.58 & $2,297.2$ & $S$ & - & EMP \\
\hline & & & & & 10-16-1999 & 1151 & 21.73 & $2,297.1$ & $S$ & - & EMP \\
\hline & & & & & $10-26-1999$ & 0830 & 21.45 & $2,297.4$ & $\mathrm{~T}$ & - & USFWS \\
\hline & & & & & 11-04-1999 & 0915 & 21.50 & $2,297.3$ & $\mathrm{~S}$ & - & EMP \\
\hline & & & & & 11-16-1999 & 0950 & 21.47 & $2,297.3$ & $\mathrm{~T}$ & - & USFWS \\
\hline & & & & & $12-10-1999$ & 1003 & 21.49 & $2,297.3$ & $\mathrm{~S}$ & - & EMP \\
\hline & & & & & $12-20-1999$ & 1555 & 21.45 & $2,297.4$ & $\mathrm{~T}$ & - & USFWS \\
\hline
\end{tabular}


Table 5. Periodic water-level data at monitoring sites in Yucca Mountain region for calendar year 1999-Continued

\begin{tabular}{|c|c|c|c|c|c|c|c|c|c|c|c|}
\hline \multirow[b]{2}{*}{$\begin{array}{lc}\infty & \text { Site } \\
\frac{D}{\Phi} & \text { number } \\
\frac{0}{\mathbb{Q}} & \text { (fig. 1) } \\
\frac{\mathbb{Q}}{2} & \end{array}$} & \multirow[b]{2}{*}{$\begin{array}{l}\text { U.S. Geological } \\
\text { Survey site } \\
\text { identification }\end{array}$} & \multirow[b]{2}{*}{ Site name } & \multirow[b]{2}{*}{$\begin{array}{l}\text { Land-surface } \\
\text { altitude } \\
\text { (feet above } \\
\text { sea level) }\end{array}$} & \multirow[b]{2}{*}{$\begin{array}{l}\text { Height of } \\
\text { measurement } \\
\text { point (feet } \\
\text { above land } \\
\text { surface) }\end{array}$} & \multicolumn{7}{|c|}{ Water-level measurement } \\
\hline & & & & & Date & Time & $\begin{array}{l}\text { Depth to water } \\
\text { (feet below } \\
\text { land } \\
\text { surface) }\end{array}$ & $\begin{array}{c}\text { Altitude of } \\
\text { water surface } \\
\text { (feet above } \\
\text { sea level) }\end{array}$ & Method & $\begin{array}{l}\text { Site } \\
\text { status }\end{array}$ & $\begin{array}{c}\text { Data } \\
\text { source }\end{array}$ \\
\hline \multirow[t]{25}{*}{ AM-7 } & \multirow[t]{25}{*}{362417116163600} & \multirow[t]{25}{*}{ Point of Rocks South Well } & \multirow[t]{25}{*}{$2,333.5$} & \multirow[t]{25}{*}{0.8} & 01-19-1999 & 1645 & 7.44 & $2,326.1$ & $\mathrm{~T}$ & - & USFWS \\
\hline & & & & & 01-27-1999 & 1020 & 7.48 & $2,326.0$ & $S$ & - & EMP \\
\hline & & & & & 02-19-1999 & 0745 & 7.47 & $2,326.0$ & S & - & EMP \\
\hline & & & & & 02-24-1999 & 1045 & 7.45 & $2,326.0$ & $\mathrm{~T}$ & - & USFWS \\
\hline & & & & & 03-16-1999 & 0845 & 7.46 & $2,326.0$ & $\mathrm{~S}$ & - & EMP \\
\hline & & & & & 03-24-1999 & 1055 & 7.49 & $2,326.0$ & $\mathrm{~T}$ & - & USFWS \\
\hline & & & & & 04-13-1999 & 1426 & 7.52 & $2,326.0$ & $\mathrm{~S}$ & - & EMP \\
\hline & & & & & 04-26-1999 & 1040 & 7.51 & $2,326.0$ & $\mathrm{~T}$ & - & USFWS \\
\hline & & & & & 05-18-1999 & 1252 & 7.46 & $2,326.0$ & S & - & EMP \\
\hline & & & & & 05-19-1999 & 1145 & 7.46 & $2,326.0$ & $\mathrm{~T}$ & - & USFWS \\
\hline & & & & & 06-15-1999 & 0950 & 7.49 & $2,326.0$ & S & - & EMP \\
\hline & & & & & 06-21-1999 & 1200 & 7.49 & $2,326.0$ & $\mathrm{~T}$ & - & USFWS \\
\hline & & & & & 07-13-1999 & 1550 & 7.51 & $2,326.0$ & $\mathrm{~T}$ & - & USFWS \\
\hline & & & & & 07-27-1999 & 1100 & 7.53 & $2,326.0$ & S & - & EMP \\
\hline & & & & & 08-05-1999 & 1951 & 7.41 & $2,326.1$ & $\mathrm{~S}$ & - & EMP \\
\hline & & & & & 08-19-1999 & 1030 & 7.44 & $2,326.1$ & $\mathrm{~T}$ & - & USFWS \\
\hline & & & & & 09-17-1999 & 1131 & 7.40 & $2,326.1$ & S & - & EMP \\
\hline & & & & & 09-29-1999 & 0850 & 7.39 & $2,326.1$ & $\mathrm{~T}$ & - & USFWS \\
\hline & & & & & 10-07-1999 & 1732 & 7.33 & $2,326.2$ & $\mathrm{~S}$ & - & EMP \\
\hline & & & & & 10-16-1999 & 1133 & 6.62 & $2,326.9$ & $\mathrm{~S}$ & - & EMP \\
\hline & & & & & $10-26-1999$ & 0850 & 6.69 & $2,326.8$ & $\mathrm{~T}$ & - & USFWS \\
\hline & & & & & 11-04-1999 & 0930 & 6.76 & $2,326.7$ & S & - & EMP \\
\hline & & & & & 11-16-1999 & 1010 & 6.86 & $2,326.6$ & $\mathrm{~T}$ & - & USFWS \\
\hline & & & & & $12-10-1999$ & 1020 & 7.05 & $2,326.4$ & S & - & EMP \\
\hline & & & & & $12-20-1999$ & 1605 & 7.11 & $2,326.4$ & $\mathrm{~T}$ & - & USFWS \\
\hline \multirow[t]{13}{*}{ DV-3 } & \multirow[t]{13}{*}{362230116392901} & \multirow[t]{13}{*}{ Travertine Point 1 Well } & \multirow[t]{13}{*}{$2,728.4$} & \multirow[t]{13}{*}{2.0} & 01-27-1999 & 1420 & 601.11 & $2,127.3$ & $\mathrm{~V}$ & - & EMP \\
\hline & & & & & 02-23-1999 & 1404 & 601.24 & $2,127.2$ & $\mathrm{~V}$ & - & EMP \\
\hline & & & & & 03-16-1999 & 1029 & 601.16 & $2,127.2$ & $\mathrm{~V}$ & - & EMP \\
\hline & & & & & 04-13-1999 & 0915 & 601.13 & $2,127.3$ & $\mathrm{~V}$ & - & EMP \\
\hline & & & & & 05-18-1999 & 0800 & 601.19 & $2,127.2$ & $\mathrm{~V}$ & - & EMP \\
\hline & & & & & 06-14-1999 & 1443 & 601.09 & $2,127.3$ & $\mathrm{~V}$ & - & EMP \\
\hline & & & & & 07-27-1999 & 0702 & 601.25 & $2,127.2$ & $\mathrm{~V}$ & - & EMP \\
\hline & & & & & 08-06-1999 & 0732 & 601.23 & $2,127.2$ & V & - & EMP \\
\hline & & & & & 09-23-1999 & 1049 & 601.32 & $2,127.1$ & V & - & EMP \\
\hline & & & & & 10-08-1999 & 1019 & 601.41 & $2,127.0$ & $\mathrm{~V}$ & - & EMP \\
\hline & & & & & 10-19-1999 & 1147 & 601.42 & $2,127.0$ & V & - & EMP \\
\hline & & & & & 11-03-1999 & 1309 & 601.39 & $2,127.0$ & $\mathrm{~V}$ & - & EMP \\
\hline & & & & & 12-13-1999 & 1020 & 601.36 & $2,127.0$ & $\mathrm{~V}$ & - & EMP \\
\hline
\end{tabular}


Table 6. Daily average water levels in well JF-3 for calendar year 1999

[Symbol: —, data not available]

\begin{tabular}{|c|c|c|c|c|c|c|c|c|c|c|c|c|}
\hline \multirow{2}{*}{ Day } & \multicolumn{12}{|c|}{ Water level, in feet below land surface } \\
\hline & Jan. & Feb. & Mar. & Apr. & May & June & July & Aug. & Sept. & Oct. & Nov. & Dec. \\
\hline 1 & 710.26 & 710.39 & 710.12 & 710.05 & 710.29 & 710.03 & 709.98 & 710.09 & 709.95 & 709.87 & 710.06 & 709.91 \\
\hline 2 & 710.27 & 710.36 & 710.08 & 710.13 & 710.02 & 709.90 & 709.91 & 710.23 & 710.01 & 709.89 & 710.03 & 709.92 \\
\hline 3 & 710.37 & 710.09 & 709.85 & 710.00 & 709.91 & 710.04 & 709.98 & 710.18 & 710.10 & 710.10 & 709.98 & 710.13 \\
\hline 4 & 710.40 & 709.92 & 709.94 & 710.13 & 710.17 & 710.08 & 710.16 & 710.07 & 710.20 & 710.13 & 709.93 & 710.22 \\
\hline 5 & 710.27 & 710.20 & 710.13 & 710.21 & 710.38 & 710.22 & 710.29 & 709.97 & 710.20 & 709.97 & 710.06 & 710.08 \\
\hline 6 & 710.12 & 710.29 & 709.99 & 710.21 & 710.31 & 710.14 & 710.23 & 710.02 & 710.13 & 709.87 & 710.10 & 709.94 \\
\hline 7 & 709.96 & 710.17 & 709.97 & 710.30 & 710.09 & 710.05 & 710.21 & 710.15 & 710.14 & 710.18 & 709.93 & 709.74 \\
\hline 8 & 710.26 & 710.11 & 710.19 & 710.32 & 709.97 & 710.03 & 710.29 & 710.15 & 710.14 & 710.20 & 709.93 & 710.08 \\
\hline 9 & 710.34 & 709.97 & 710.14 & 710.34 & 710.05 & 710.06 & 710.32 & 710.04 & 710.08 & 710.12 & 710.05 & 709.98 \\
\hline 10 & 710.21 & 710.38 & 710.19 & 710.32 & 710.17 & 710.11 & 710.28 & 710.00 & 710.05 & 710.09 & 710.04 & 709.86 \\
\hline 11 & 709.98 & 710.70 & 710.11 & 710.13 & 710.20 & 710.17 & 710.17 & 710.16 & 710.11 & 710.09 & 710.14 & 710.13 \\
\hline 12 & 710.00 & 710.47 & 710.37 & 710.22 & 710.04 & 710.23 & 710.16 & 710.22 & 710.19 & 710.14 & 710.15 & 710.10 \\
\hline 13 & 710.25 & 710.21 & 710.30 & 710.31 & 709.94 & 710.20 & 710.07 & 710.12 & 710.16 & 710.10 & 710.10 & 709.91 \\
\hline 14 & 710.35 & 709.97 & 710.09 & 710.35 & 710.08 & 710.12 & 710.02 & 710.00 & 710.04 & 709.92 & 710.05 & 710.21 \\
\hline 15 & 710.09 & 710.11 & 709.94 & 710.32 & 710.17 & 710.04 & 710.03 & 710.14 & 710.02 & 709.86 & 709.98 & 710.21 \\
\hline 16 & 709.95 & 710.12 & 710.10 & 710.27 & 710.29 & 710.05 & 710.08 & 710.28 & 710.07 & 710.27 & 709.84 & 710.06 \\
\hline 17 & 710.12 & 710.09 & 710.21 & 710.22 & 710.29 & 710.12 & 710.12 & 710.23 & 710.13 & 710.35 & 709.80 & 710.00 \\
\hline 18 & 710.14 & 710.02 & 710.31 & 710.19 & 710.09 & 710.13 & 710.18 & 710.05 & 710.09 & 710.12 & 710.09 & 709.87 \\
\hline 19 & 710.09 & 710.17 & 710.27 & 710.09 & 710.03 & 710.07 & 710.18 & 710.08 & 710.03 & 710.16 & 710.12 & 710.01 \\
\hline 20 & 709.97 & 710.31 & 710.15 & 709.88 & 710.06 & 709.99 & 710.14 & 710.14 & 710.19 & 710.17 & 709.97 & 710.05 \\
\hline 21 & 710.15 & 710.15 & 710.23 & 709.75 & 710.06 & 709.93 & 710.16 & 710.09 & 710.20 & 710.11 & 709.92 & 709.98 \\
\hline 22 & 710.33 & 710.42 & 710.14 & 709.83 & 710.08 & 710.08 & 710.22 & 710.05 & 710.12 & 710.02 & 710.20 & 710.23 \\
\hline 23 & 710.04 & 710.27 & 710.05 & 710.04 & 710.23 & 710.14 & 710.17 & 710.07 & 710.04 & 710.00 & 710.23 & 710.28 \\
\hline 24 & 709.99 & 710.08 & 710.14 & 710.20 & 710.25 & 710.07 & 710.06 & 710.08 & 710.07 & 710.04 & 710.30 & 710.20 \\
\hline 25 & 709.94 & 709.91 & 710.09 & 710.25 & 710.16 & 710.01 & 710.09 & 710.07 & 710.05 & 710.09 & 710.12 & 710.00 \\
\hline 26 & 710.15 & 710.13 & 710.02 & 710.16 & 710.17 & 710.01 & 710.11 & 710.03 & 709.96 & 709.98 & 709.86 & 710.02 \\
\hline 27 & 710.44 & 710.26 & 710.16 & 710.01 & 710.16 & 710.13 & 710.10 & 710.06 & 709.98 & 709.97 & 709.92 & 710.09 \\
\hline 28 & 710.47 & 710.23 & 710.35 & 709.85 & 710.02 & 710.21 & 710.14 & 710.10 & 710.31 & 709.92 & 710.16 & 709.98 \\
\hline 29 & 710.38 & - & 710.22 & 710.04 & 709.94 & 710.19 & 710.18 & 710.07 & 710.24 & 710.22 & 710.18 & 709.78 \\
\hline 30 & 710.21 & - & 709.89 & 710.29 & 710.09 & 710.07 & 710.08 & 709.99 & 710.02 & 710.28 & 709.96 & 709.80 \\
\hline 31 & 710.06 & - & 709.90 & - & 710.16 & - & 710.04 & 710.04 & - & 710.14 & - & 709.68 \\
\hline Mean & 710.18 & 710.20 & 710.12 & 710.15 & 710 & 710.09 & 710.13 & 710.10 & 710.10 & 710.08 & 710.04 & 710.01 \\
\hline Maximum & 710.47 & 710.70 & 710.37 & 710.35 & 710.38 & 710.23 & 710.32 & 710.28 & 710.31 & 710.35 & 710.30 & 710.28 \\
\hline Minimum & 709.94 & 709.91 & 709.85 & 709.75 & 709.91 & 709.90 & 709.91 & 709.97 & 709.95 & 709.86 & 709.80 & 709.68 \\
\hline
\end{tabular}


Table 7. Daily average water levels in well AD-6 for calendar year 1999

[Symbol: - , data not available]

\begin{tabular}{|c|c|c|c|c|c|c|c|c|c|c|c|c|}
\hline \multirow{2}{*}{ Day } & \multicolumn{12}{|c|}{ Water level, in feet below land surface } \\
\hline & Jan. & Feb. & Mar. & Apr. & May & June & July & Aug. & Sept. & Oct. & Nov. & Dec. \\
\hline 1 & 41.74 & 41.75 & 41.59 & 41.57 & 41.64 & 41.55 & 41.48 & 41.58 & 41.53 & 41.51 & 41.71 & 41.68 \\
\hline 2 & 41.71 & 41.72 & 41.58 & 41.59 & 41.52 & 41.51 & 41.46 & 41.64 & 41.56 & 41.53 & 41.71 & 41.69 \\
\hline 3 & 41.76 & 41.60 & 41.48 & 41.53 & 41.50 & 41.58 & 41.50 & 41.61 & 41.58 & 41.62 & 41.69 & 41.79 \\
\hline 4 & 41.78 & 41.54 & 41.55 & 41.60 & 41.61 & 41.59 & 41.57 & 41.57 & 41.61 & 41.61 & 41.67 & 41.82 \\
\hline 5 & 41.73 & 41.68 & 41.62 & 41.61 & 41.68 & 41.63 & 41.61 & 41.53 & 41.60 & 41.54 & 41.72 & 41.76 \\
\hline 6 & 41.67 & 41.69 & 41.54 & 41.60 & 41.63 & 41.57 & 41.58 & 41.57 & 41.57 & 41.51 & 41.73 & 41.70 \\
\hline 7 & 41.61 & 41.63 & 41.54 & 41.65 & 41.53 & 41.55 & 41.58 & 41.62 & 41.58 & 41.65 & 41.66 & 41.62 \\
\hline 8 & 41.75 & 41.61 & 41.64 & 41.66 & 41.50 & 41.54 & 41.63 & 41.61 & 41.58 & 41.63 & 41.67 & 41.79 \\
\hline 9 & 41.76 & 41.55 & 41.60 & 41.68 & 41.55 & 41.55 & 41.64 & 41.56 & 41.56 & 41.60 & 41.73 & 41.71 \\
\hline 10 & 41.70 & 41.75 & 41.61 & 41.66 & 41.60 & 41.57 & 41.62 & 41.55 & 41.55 & 41.59 & 41.71 & 41.66 \\
\hline 11 & 41.61 & 41.86 & 41.58 & 41.58 & 41.60 & 41.59 & 41.59 & 41.62 & 41.58 & 41.59 & 41.75 & 41.79 \\
\hline 12 & 41.63 & 41.74 & 41.69 & 41.63 & 41.52 & 41.61 & 41.59 & 41.63 & 41.61 & 41.61 & 41.75 & 41.76 \\
\hline 13 & 41.73 & 41.65 & 41.64 & 41.65 & 41.49 & 41.59 & 41.56 & 41.58 & 41.59 & 41.59 & 41.73 & 41.68 \\
\hline 14 & 41.75 & 41.56 & 41.55 & 41.66 & 41.56 & 41.56 & 41.55 & 41.54 & 41.54 & 41.52 & 41.71 & 41.82 \\
\hline 15 & 41.64 & 41.64 & 41.50 & 41.65 & 41.60 & 41.53 & 41.55 & 41.61 & 41.55 & 41.51 & 41.68 & 41.82 \\
\hline 16 & 41.59 & 41.62 & 41.59 & 41.64 & 41.64 & 41.54 & 41.56 & 41.66 & 41.57 & 41.78 & 41.63 & 41.75 \\
\hline 17 & 41.67 & 41.61 & 41.62 & 41.63 & 41.63 & 41.57 & 41.58 & 41.62 & 41.59 & 41.81 & 41.63 & 41.73 \\
\hline 18 & 41.66 & 41.57 & 41.65 & 41.62 & 41.54 & 41.57 & 41.60 & 41.55 & 41.58 & 41.71 & 41.76 & 41.67 \\
\hline 19 & 41.63 & 41.64 & 41.62 & 41.57 & 41.54 & 41.54 & 41.60 & 41.57 & 41.55 & 41.74 & 41.75 & 41.73 \\
\hline 20 & 41.59 & 41.69 & 41.58 & 41.49 & 41.55 & 41.51 & 41.58 & 41.60 & 41.63 & 41.74 & 41.68 & 41.74 \\
\hline 21 & 41.67 & 41.62 & 41.63 & 41.45 & 41.54 & 41.48 & 41.60 & 41.57 & 41.62 & 41.72 & 41.67 & 41.71 \\
\hline 22 & 41.74 & 41.75 & 41.59 & 41.50 & 41.55 & 41.55 & 41.62 & 41.56 & 41.59 & 41.69 & 41.80 & 41.82 \\
\hline 23 & 41.61 & 41.67 & 41.56 & 41.59 & 41.62 & 41.56 & 41.60 & 41.57 & 41.57 & 41.69 & 41.80 & 41.82 \\
\hline 24 & 41.60 & 41.59 & 41.59 & 41.64 & 41.62 & 41.53 & 41.55 & 41.57 & 41.58 & 41.70 & 41.82 & 41.79 \\
\hline 25 & 41.58 & 41.53 & 41.56 & 41.63 & 41.58 & 41.51 & 41.57 & 41.57 & 41.57 & 41.72 & 41.75 & 41.72 \\
\hline 26 & 41.67 & 41.64 & 41.53 & 41.58 & 41.59 & 41.52 & 41.57 & 41.55 & 41.53 & 41.67 & 41.65 & 41.75 \\
\hline 27 & 41.78 & 41.67 & 41.60 & 41.52 & 41.59 & 41.56 & 41.57 & 41.57 & 41.55 & 41.67 & 41.69 & 41.78 \\
\hline 28 & 41.77 & 41.64 & 41.66 & 41.47 & 41.53 & 41.58 & 41.59 & 41.58 & 41.68 & 41.65 & 41.79 & 41.73 \\
\hline 29 & 41.73 & - & 41.60 & 41.58 & 41.51 & 41.56 & 41.61 & 41.57 & 41.65 & 41.80 & 41.78 & 41.66 \\
\hline 30 & 41.66 & - & 41.47 & 41.66 & 41.58 & 41.51 & 41.56 & 41.54 & 41.56 & 41.80 & 41.68 & 41.67 \\
\hline 31 & 41.61 & - & 41.51 & - & 41.60 & - & 41.55 & 41.57 & - & 41.74 & - & 41.61 \\
\hline Mean & 41.68 & 41.65 & 41.58 & 41.60 & 41.57 & 41.55 & 41.57 & 41.58 & 41.58 & 41.65 & 41.72 & 41.73 \\
\hline Maximum & 41.78 & 41.86 & 41.69 & 41.68 & 41.68 & 41.63 & 41.64 & 41.66 & 41.68 & 41.81 & 41.82 & 41.82 \\
\hline Minimum & 41.58 & 41.53 & 41.47 & 41.45 & 41.49 & 41.48 & 41.46 & 41.53 & 41.53 & 41.51 & 41.63 & 41.61 \\
\hline
\end{tabular}

$(1999$ annual summary: mean $=41.62 ;$ maximum $=41.86 ;$ minimum $=41.45)$ 
Table 8. Ground-water-discharge data at monitoring sites in Yucca Mountain region for calendar year 1999

Site number: Sites are grouped by hydrographic area and, within each area, are listed in general north-to-south, then west-to-east order. See section "Site Number" for further discussion.

U.S. Geological Survev site identification: Unique identification number for site as stored in files and data bases of U.S. Geological Survey (USGS).

Discharge: Reported to two significant figures.

Method: Method used to measure discharge. C, current meter; F, flume; V, volumetric; Z, discharge represents monthly mean discharge on basis of continually recorded stage (see section "Ground-Water Discharge Data" for further discussion).

Datalsource: EMP, Environmental-Monitoring Program (USGS); NPS, National Park Service; USFWS, U.S. Fish \& Wildlife Service.

\begin{tabular}{|c|c|c|c|c|c|c|c|}
\hline \multirow{2}{*}{$\begin{array}{c}\text { Site } \\
\text { number } \\
\text { (fig.1) }\end{array}$} & \multirow{2}{*}{$\begin{array}{l}\text { U.S. Geological } \\
\text { Survey site } \\
\text { identification }\end{array}$} & \multirow[b]{2}{*}{ Site name } & \multicolumn{5}{|c|}{ Discharge measurement } \\
\hline & & & Date & Time & $\begin{array}{c}\text { Discharge } \\
\text { (gallons per } \\
\text { minute) }\end{array}$ & Method & $\begin{array}{c}\text { Data } \\
\text { source }\end{array}$ \\
\hline \multirow[t]{17}{*}{ AM-1a } & 362924116203001 & Fairbanks Spring & 01-19-1999 & 1500 & 1,800 & $\mathrm{~F}$ & USFWS \\
\hline & & & 02-22-1999 & 1338 & 1,600 & $\mathrm{C}$ & EMP \\
\hline & & & 02-23-1999 & 1225 & 1,800 & $\mathrm{~F}$ & USFWS \\
\hline & & & 03-24-1999 & 1440 & 1,800 & $\mathrm{~F}$ & USFWS \\
\hline & & & 04-06-1999 & 0925 & 1,800 & $\mathrm{~F}$ & USFWS \\
\hline & & & 05-19-1999 & 0955 & 1,800 & $\mathrm{~F}$ & USFWS \\
\hline & & & 05-25-1999 & 1042 & 1,600 & $\mathrm{C}$ & EMP \\
\hline & & & 06-21-1999 & 1030 & 1,800 & $\mathrm{~F}$ & USFWS \\
\hline & & & 07-12-1999 & 1515 & 1,800 & $\mathrm{~F}$ & USFWS \\
\hline & & & 07-30-1999 & 0900 & 1,800 & $\mathrm{~F}$ & USFWS \\
\hline & & & 08-18-1999 & 1004 & 1,600 & $\mathrm{C}$ & EMP \\
\hline & & & 08-23-1999 & 1105 & 1,800 & $\mathrm{~F}$ & USFWS \\
\hline & & & 09-24-1999 & 1230 & 1,800 & $\mathrm{~F}$ & USFWS \\
\hline & & & 10-13-1999 & 0925 & 1,800 & $\mathrm{~F}$ & USFWS \\
\hline & & & $11-15-1999$ & 1007 & 1,700 & $\mathrm{C}$ & EMP \\
\hline & & & 11-24-1999 & 1155 & 1,800 & $\mathrm{~F}$ & USFWS \\
\hline & & & $12-21-1999$ & 1500 & 1,800 & $\mathrm{~F}$ & USFWS \\
\hline \multirow[t]{13}{*}{ AM-2 } & 362755116190401 & Five Springs Well & 01-27-1999 & 0820 & 39 & $\mathrm{~V}$ & EMP \\
\hline & & & 02-19-1999 & 0858 & 40 & $\mathrm{~V}$ & EMP \\
\hline & & & 03-24-1999 & 0902 & 40 & $\mathrm{~V}$ & EMP \\
\hline & & & 04-13-1999 & 1124 & 38 & $\mathrm{~V}$ & EMP \\
\hline & & & 05-18-1999 & 1014 & 39 & $\mathrm{~V}$ & EMP \\
\hline & & & 06-15-1999 & 0729 & 42 & $\mathrm{~V}$ & EMP \\
\hline & & & 07-27-1999 & 0903 & 41 & $\mathrm{~V}$ & EMP \\
\hline & & & 08-25-1999 & 1818 & 44 & $\mathrm{~V}$ & EMP \\
\hline & & & 09-29-1999 & 1005 & 42 & $\mathrm{~V}$ & EMP \\
\hline & & & 10-07-1999 & 1530 & 43 & $\mathrm{~V}$ & EMP \\
\hline & & & 10-18-1999 & 1617 & 59 & $\mathrm{~V}$ & EMP \\
\hline & & & 11-04-1999 & 1059 & 58 & $\mathrm{~V}$ & EMP \\
\hline & & & 12-10-1999 & 1132 & 55 & $\mathrm{~V}$ & EMP \\
\hline \multirow[t]{5}{*}{ AM-5a } & 362502116192301 & Crystal Pool & 01-20-1999 & 0900 & 3,000 & $\mathrm{C}$ & USFWS \\
\hline & & & 02-22-1999 & 1146 & 3,000 & $\mathrm{C}$ & EMP \\
\hline & & & 02-25-1999 & 1330 & 2,800 & $\mathrm{C}$ & USFWS \\
\hline & & & 03-24-1999 & 1510 & 2,900 & $\mathrm{C}$ & USFWS \\
\hline & & & 04-06-1999 & 1400 & 2,900 & $\mathrm{C}$ & USFWS \\
\hline
\end{tabular}


Table 8. Ground-water-discharge data at monitoring sites in Yucca mountain region for calendar year 1999—Continued

\begin{tabular}{|c|c|c|c|c|c|c|c|}
\hline \multirow{2}{*}{$\begin{array}{c}\text { Site } \\
\text { number } \\
\text { (fig.1) }\end{array}$} & \multirow{2}{*}{$\begin{array}{c}\text { U.S. Geological } \\
\text { Survey site } \\
\text { identification }\end{array}$} & \multirow[b]{2}{*}{ Site name } & \multicolumn{5}{|c|}{ Discharge measurement } \\
\hline & & & Date & Time & $\begin{array}{l}\text { Discharge } \\
\text { (gallons per } \\
\text { minute) }\end{array}$ & Method & $\begin{array}{l}\text { Data } \\
\text { source }\end{array}$ \\
\hline \multirow[t]{12}{*}{ AM-5a } & 362502116192301 & Crystal Pool & 04-26-1999 & 1630 & 3,000 & $\mathrm{C}$ & USFWS \\
\hline & & & 05-20-1999 & 0845 & 2,900 & $\mathrm{C}$ & USFWS \\
\hline & & & 05-20-1999 & 0947 & 3,000 & $\mathrm{C}$ & EMP \\
\hline & & & 06-21-1999 & 1530 & 2,600 & $\mathrm{C}$ & USFWS \\
\hline & & & 07-30-1999 & 1210 & 2,500 & $\mathrm{C}$ & USFWS \\
\hline & & & 08-18-1999 & 0707 & 2,500 & $\mathrm{C}$ & EMP \\
\hline & & & 08-19-1999 & 1345 & 2,600 & $\mathrm{C}$ & USFWS \\
\hline & & & 09-29-1999 & 1050 & 2,800 & $\mathrm{C}$ & USFWS \\
\hline & & & 10-19-1999 & 1550 & 2,700 & $\mathrm{C}$ & USFWS \\
\hline & & & $11-15-1999$ & 1157 & 2,700 & $\mathrm{C}$ & EMP \\
\hline & & & 11-30-1999 & 1445 & 2,700 & $\mathrm{C}$ & USFWS \\
\hline & & & 12-21-1999 & 1115 & 2,700 & $\mathrm{C}$ & USFWS \\
\hline \multirow[t]{16}{*}{ AM-8 } & 362230116162001 & Big Spring & 01-20-1999 & 1445 & 1,200 & $\mathrm{C}$ & USFWS \\
\hline & & & 02-22-1999 & 0959 & 970 & $\mathrm{C}$ & EMP \\
\hline & & & 02-25-1999 & 1435 & 1,000 & $\mathrm{C}$ & USFWS \\
\hline & & & 03-24-1999 & 0935 & 1,000 & $\mathrm{C}$ & USFWS \\
\hline & & & 04-26-1999 & 1420 & 930 & $\mathrm{C}$ & USFWS \\
\hline & & & 05-24-1999 & 1040 & 1,100 & $\mathrm{C}$ & USFWS \\
\hline & & & 05-25-1999 & 1154 & 1,100 & $\mathrm{C}$ & EMP \\
\hline & & & 06-22-1999 & 1130 & 1,000 & $\mathrm{C}$ & USFWS \\
\hline & & & 07-30-1999 & 1335 & 1,100 & $\mathrm{C}$ & USFWS \\
\hline & & & 08-18-1999 & 0859 & 990 & $\mathrm{C}$ & EMP \\
\hline & & & 08-19-1999 & 0835 & 1,000 & $\mathrm{C}$ & USFWS \\
\hline & & & 09-29-1999 & 1530 & 1,200 & $\mathrm{C}$ & USFWS \\
\hline & & & 10-19-1999 & 0850 & 1,200 & $\mathrm{C}$ & USFWS \\
\hline & & & 11-16-1999 & 0716 & 1,100 & $\mathrm{C}$ & EMP \\
\hline & & & 11-24-1999 & 1445 & 1,200 & $\mathrm{C}$ & USFWS \\
\hline & & & $12-21-1999$ & 0840 & 930 & $\mathrm{C}$ & USFWS \\
\hline \multirow[t]{10}{*}{ DV-1 } & 362728116501101 & Texas Spring & 01-15-1999 & & 200 & $\mathrm{Z}$ & NPS \\
\hline & & & 02-15-1999 & - & 200 & $\mathrm{Z}$ & NPS \\
\hline & & & 02-18-1999 & 0824 & 190 & $\mathrm{C}$ & EMP \\
\hline & & & 03-15-1999 & - & 200 & $\mathrm{Z}$ & NPS \\
\hline & & & 04-15-1999 & - & 200 & $\mathrm{Z}$ & NPS \\
\hline & & & 05-15-1999 & - & 200 & $\mathrm{Z}$ & NPS \\
\hline & & & 05-25-1999 & 0804 & 210 & $\mathrm{C}$ & EMP \\
\hline & & & 06-15-1999 & - & 200 & $\mathrm{Z}$ & NPS \\
\hline & & & 07-15-1999 & - & 200 & $\mathrm{Z}$ & NPS \\
\hline & & & 09-30-1999 & 1258 & 190 & $\mathrm{C}$ & EMP \\
\hline \multirow[t]{4}{*}{ DV-2 } & 362252116425301 & Navel Spring & 02-18-1999 & 1140 & .90 & V & EMP \\
\hline & & & 05-25-1999 & 0900 & .90 & $\mathrm{~V}$ & EMP \\
\hline & & & 08-26-1999 & 1212 & 1.0 & $\mathrm{~V}$ & EMP \\
\hline & & & 11-03-1999 & 1640 & 1.4 & $\mathrm{~V}$ & EMP \\
\hline
\end{tabular}


Table 9. Estimated annual ground-water withdrawals from wells in Yucca Mountain region for calendar year 1999

\begin{tabular}{|c|c|c|c|}
\hline \multirow[b]{2}{*}{ Ground-water subbasin (fig. 1) } & \multirow[b]{2}{*}{ Hydrographic area (fig. 1) } & \multicolumn{2}{|c|}{ Ground-water withdrawal ${ }^{1}$} \\
\hline & & $\begin{array}{l}\text { Millions of } \\
\text { gallons }\end{array}$ & Acre-feet \\
\hline \multirow[t]{3}{*}{ Alkali Flat-Furnace Creek Ranch } & Amargosa Desert ${ }^{2}$ & 4,598 & 14,110 \\
\hline & Crater Flat ${ }^{3}$ & 90.2 & 277 \\
\hline & Jackass Flats ${ }^{3}$ & 33.3 & 102 \\
\hline \multirow[t]{3}{*}{ Ash Meadows } & $\begin{array}{l}\text { Amargosa Desert }^{2} \\
\quad \text { (excluding Ash Meadows area) }\end{array}$ & 20 & 60 \\
\hline & $\begin{array}{l}\text { Amargosa Desert }{ }^{2} \\
\quad \text { (Ash Meadows area) }\end{array}$ & 3 & 8 \\
\hline & Mercury Valley ${ }^{3}$ & 79.7 & 245 \\
\hline \multicolumn{4}{|c|}{$\begin{array}{l}\text { Domestic use within each part of the Amargosa Desert is based on location and number of wells drilled for domestic pur- } \\
\text { poses (as stored in files maintained by Nevada Divison of Water Resources). Conversion to millions of gallons ( } 325,851 \\
\text { gallons per acre-foot) is rounded to nearest } 1 \text { million gallons. } \\
{ }^{3} \text { Data reported or recompiled from flowmeter readings and listed to nearest } 0.1 \text { million gallons. Conversions to } \\
\text { acre-feet are rounded to nearest acre-foot. }\end{array}$} \\
\hline
\end{tabular}


Table 10. Minimum, maximum, and median water-level altitudes, and average deviation of measurements, at wells in Jackass Flats for selected baseline periods and for calendar years 1992 through 1999. Excludes water-level altitudes that may reflect short-term conditions at a site

Calendar years: Years for which measurements were used to calculate summary statistics. Italics indicate selected baseline period.

Number: Number of water-level measurements for year(s) specified. For JF-2 (1985-93), JF-2a (1985-97), and JF-3, value represents number of daily average water levels.

Water level: Based on periodic water-level measurements made during site visits for JF-1, JF-2 (after 1993), JF-2a (after 1997), $\mathrm{J}-13$, J-11, and J-12. Based on daily average water levels collected from continual data recorders for JF-2 (1985-93), JF-2a (198597), and JF-3.

Minimum: Minimum water-level altitude or minimum daily average water-level altitude for year(s) specified.

Maximum: Maximum water-level altitude or maximum daily average water-level altitude for year(s) specified.

Median: Statistically representative water-level altitude calculated from periodic measurements or daily average water levels for year(s) specified.

Average deviation: Calculated dispersion of measurements about median water-level altitude. Average deviation is equal to sum of absolute differences between measured water levels and median, divided by number of measurements.

Change in median: Differences between median water level for calendar years 1992, 1993, 1994, 1995, 1996, 1997, 1998, and t999 compared with baseline period. Minus sign indicates that median water-level altitude was lower for the specified year than for the baseline period.

me

19lopreviations and symbols: N/A, not applicable (data field is not related to referenced data set)]

\begin{tabular}{|c|c|c|c|c|c|c|c|}
\hline \multirow{2}{*}{$\begin{array}{c}\text { Site } \\
\text { number } \\
\text { (fig. 1) }\end{array}$} & \multirow{2}{*}{$\begin{array}{c}\text { Calendar } \\
\text { year(s) }\end{array}$} & \multirow{2}{*}{ Number } & \multicolumn{3}{|c|}{ Water level (feet above sea level) } & \multirow{2}{*}{$\begin{array}{c}\text { Average } \\
\text { deviation } \\
\text { (feet) }\end{array}$} & \multirow{2}{*}{$\begin{array}{l}\text { Change in } \\
\text { median } \\
\text { (feet) }\end{array}$} \\
\hline & & & Minimum & Maximum & Median & & \\
\hline JF-1 & 1985-91 & 86 & $2,391.7$ & $2,393.1$ & $2,392.5$ & 0.2 & N/A \\
\hline JF-2 & 1985-91 & 1,777 & $2,389.6$ & $2,393.4$ & $2,392.1$ & .3 & N/A \\
\hline $\mathrm{JF}-2 \mathrm{a}$ & 1985-91 & 1,876 & $2,466.7$ & $2,469.5$ & $2,468.6$ & .4 & N/A \\
\hline $\mathrm{J}-13$ & 1989-91 & 32 & $2,389.7$ & $2,390.7$ & $2,390.0$ & .2 & N/A \\
\hline $\mathrm{J}-11$ & 1990-91 & 25 & $2,401.9$ & $2,402.9$ & $2,402.2$ & .1 & N/A \\
\hline $\mathrm{J}-12$ & 1990-91 & 22 & $2,388.1$ & $2,388.5$ & $2,388.3$ & .1 & N/A \\
\hline JF-3 & 1992-93 & 582 & $2,387.7$ & $2,388.8$ & $2,388.3$ & .1 & N/A \\
\hline JF-1 & 1999 & 12 & $2,392.3$ & $2,393.0$ & $2,392.7$ & .2 & 0.2 \\
\hline JF-2 & 1999 & 13 & $2,392.0$ & $2,392.7$ & $2,392.5$ & .2 & .4 \\
\hline $\mathrm{JF}-2 \mathrm{a}$ & 1999 & 13 & $2,469.8$ & $2,470.4$ & $2,470.2$ & .2 & 1.6 \\
\hline $\mathrm{J}-13$ & 1999 & 13 & 2,389.6 & $2,390.2$ & $2,390.0$ & .2 & 0 \\
\hline $\mathrm{J}-11$ & 1999 & 14 & $2,402.2$ & $2,402.8$ & $2,402.4$ & .2 & 0.2 \\
\hline $\mathrm{J}-12$ & 1999 & 12 & $2,388.1$ & $2,388.5$ & $2,388.3$ & .1 & 0 \\
\hline JF-3 & 1999 & 365 & $2,387.6$ & $2,388.6$ & $2,388.2$ & .1 & -.1 \\
\hline JF-1 & 1998 & 22 & $2,392.3$ & $2,392.8$ & $2,392.5$ & .1 & 0 \\
\hline $\mathrm{JF}-2$ & 1998 & 21 & $2,391.8$ & 2,392.6 & $2,392.1$ & .1 & 0 \\
\hline $\mathrm{JF}-2 \mathrm{a}$ & 1998 & 20 & $2,469.8$ & $2,470.4$ & $2,470.0$ & .1 & 1.4 \\
\hline $\mathrm{J}-13$ & 1998 & 20 & $2,389.4$ & $2,390.2$ & $2,389.8$ & .1 & -.2 \\
\hline $\mathrm{J}-11$ & 1998 & 20 & $2,402.2$ & $2,402.9$ & $2,402.6$ & .2 & .4 \\
\hline $\mathrm{J}-12$ & 1998 & 17 & $2,387.9$ & $2,388.3$ & $2,388.0$ & .1 & -.3 \\
\hline JF-3 & 1998 & 316 & $2,387.6$ & $2,388.6$ & $2,388.0$ & .1 & -.3 \\
\hline
\end{tabular}


Table 10. Minimum, maximum, and median water-level altitudes, and average deviation of measurements, at wells in Jackass Flats for selected baseline periods and for calendar years 1992 through 1999-Continued

\begin{tabular}{|c|c|c|c|c|c|c|c|}
\hline \multirow{2}{*}{$\begin{array}{c}\text { Site } \\
\text { number } \\
\text { (fig. 1) }\end{array}$} & \multirow{2}{*}{$\begin{array}{c}\text { Calendar } \\
\text { year(s) }\end{array}$} & \multirow{2}{*}{ Number } & \multicolumn{3}{|c|}{ Water level (feet above sea level) } & \multirow{2}{*}{$\begin{array}{c}\text { Average } \\
\text { deviation } \\
\text { (feet) }\end{array}$} & \multirow{2}{*}{$\begin{array}{c}\text { Change in } \\
\text { median } \\
\text { (feet) }\end{array}$} \\
\hline & & & Minimum & Maximum & Median & & \\
\hline JF-1 & 1997 & 10 & $2,392.1$ & $2,392.6$ & $2,392.4$ & 0.1 & -0.1 \\
\hline $\mathrm{JF}-2$ & 1997 & 11 & $2,391.8$ & $2,392.4$ & $2,392.0$ & .1 & -.1 \\
\hline$J F-2 a$ & 1997 & 267 & $2,468.8$ & $2,470.0$ & $2,469.5$ & .1 & .9 \\
\hline $\mathrm{J}-13$ & 1997 & 11 & $2,389.5$ & $2,389.9$ & $2,389.6$ & .1 & -.4 \\
\hline $\mathrm{J}-11$ & 1997 & 10 & $2,402.2$ & $2,402.8$ & $2,402.6$ & .2 & .4 \\
\hline $\mathrm{J}-12$ & 1997 & 16 & $2,387.7$ & $2,388.4$ & $2,388.0$ & .1 & -.3 \\
\hline JF-3 & 1997 & 345 & $2,387.4$ & $2,388.8$ & $2,388.0$ & .1 & -.3 \\
\hline JF-1 & 1996 & 8 & $2,392.0$ & $2,392.6$ & $2,392.3$ & .2 & -.2 \\
\hline JF-2 & 1996 & 7 & 2,391.6 & $2,392.3$ & $2,392.1$ & .2 & 0 \\
\hline $\mathrm{JF}-2 \mathrm{a}$ & 1996 & 214 & $2,468.6$ & $2,469.6$ & $2,469.3$ & .1 & .7 \\
\hline $\mathrm{J}-13$ & 1996 & 8 & $2,389.2$ & $2,389.9$ & $2,389.6$ & .1 & -.4 \\
\hline $\mathrm{J}-11$ & 1996 & 8 & $2,402.2$ & $2,402.6$ & $2,402.4$ & .1 & .2 \\
\hline $\mathrm{J}-12$ & 1996 & 18 & $2,387.5$ & $2,388.5$ & $2,388.0$ & .1 & -.3 \\
\hline JF-3 & 1996 & 359 & $2,387.5$ & $2,388.5$ & $2,388.0$ & .1 & -.3 \\
\hline JF-1 & 1995 & 7 & $2,392.3$ & $2,392.8$ & $2,392.5$ & .2 & 0 \\
\hline JF-2 & 1995 & 9 & $2,392.2$ & $2,392.5$ & $2,392.4$ & .1 & .3 \\
\hline $\mathrm{JF}-2 \mathrm{a}$ & 1995 & 357 & $2,468.7$ & $2,469.3$ & $2,469.1$ & .1 & .5 \\
\hline $\mathrm{J}-13$ & 1995 & 11 & $2,389.6$ & $2,390.4$ & $2,389.8$ & .1 & -.2 \\
\hline $\mathrm{J}-11$ & 1995 & 11 & $2,402.2$ & $2,402.5$ & $2,402.4$ & .1 & .2 \\
\hline $\mathrm{J}-12$ & 1995 & 16 & $2,388.0$ & $2,388.3$ & $2,388.2$ & .1 & -.1 \\
\hline JF-3 & 1995 & 347 & $2,387.7$ & $2,388.4$ & $2,388.1$ & .1 & -.2 \\
\hline $\mathrm{JF}-1$ & 1994 & 12 & $2,392.1$ & $2,392.6$ & $2,392.3$ & .1 & -.2 \\
\hline $\mathrm{JF}-2$ & 1994 & 9 & $2,392.0$ & $2,392.6$ & $2,392.2$ & .1 & .1 \\
\hline $\mathrm{JF}-2 \mathrm{a}$ & 1994 & 356 & $2,468.4$ & $2,469.4$ & $2,469.0$ & .1 & .4 \\
\hline $\mathrm{J}-13$ & 1994 & 23 & $2,389.4$ & $2,390.0$ & $2,389.7$ & .1 & -.3 \\
\hline $\mathrm{J}-11$ & 1994 & 12 & $2,402.0$ & $2,402.5$ & $2,402.3$ & .1 & .1 \\
\hline $\mathrm{J}-12$ & 1994 & 24 & $2,387.8$ & $2,389.1$ & $2,388.2$ & .2 & -.1 \\
\hline JF-3 & 1994 & 284 & $2,387.6$ & $2,388.6$ & $2,388.1$ & .1 & -.2 \\
\hline JF-1 & 1993 & 8 & 2,391.9 & $2,392.7$ & $2,392.5$ & .2 & 0 \\
\hline JF-2 & 1993 & 362 & $2,391.7$ & $2,392.8$ & $2,392.1$ & .2 & 0 \\
\hline JF-2a & 1993 & 365 & $2,468.4$ & $2,469.2$ & $2,468.8$ & .1 & .2 \\
\hline $\mathrm{J}-13$ & 1993 & 16 & $2,389.7$ & $2,390.7$ & 2,389.9 & .1 & -.1 \\
\hline $\mathrm{J}-11$ & 1993 & 8 & $2,401.9$ & $2,402.7$ & $2,402.2$ & .2 & 0 \\
\hline $\mathrm{J}-12$ & 1993 & 19 & $2,387.9$ & $2,389.0$ & $2,388.3$ & .1 & 0 \\
\hline JF-1 & 1992 & 12 & $2,392.3$ & $2,392.6$ & $2,392.4$ & .1 & -.1 \\
\hline JF-2 & 1992 & 357 & $2,391.8$ & 2,392.6 & $2,392.2$ & .1 & .1 \\
\hline $\mathrm{JF}-2 \mathrm{a}$ & 1992 & 342 & $2,466.9$ & $2,469.2$ & $2,468.6$ & .5 & 0 \\
\hline $\mathrm{J}-13$ & 1992 & 21 & $2,389.6$ & $2,390.4$ & $2,389.9$ & .1 & -.1 \\
\hline $\mathrm{J}-11$ & 1992 & 12 & $2,402.0$ & $2,402.6$ & $2,402.2$ & .1 & 0 \\
\hline $\mathrm{J}-12$ & 1992 & 17 & $2,388.2$ & $2,388.6$ & $2,388.3$ & .1 & 0 \\
\hline
\end{tabular}

